\title{
الحماية القانونية للمريض النفسي في ظل احترام حقوق الانسان
}

\author{
shel \\ أ.د./ غنام محممد غنام \\ أستاذ القانون الجنائي \\ كليتالقانون-جامعتقانطر
}




\section{هقدهة}

\section{هوضوع البحث:}

يتناول هذا البحث موضوع الحماية القانونية للمريض النفسي في ظل احترام

حقوق الانسان. فق بدأ الاعتراف بمجموعة من الحقوق لصالح المريض النفسي بعد أن كان المريض النفسي مهملا ليس محل اهتمام سواء على المستوى اللاخلي أو على الهى المستوى الدولي. وآية ذلك أن اتفاقيات حقوق الانسان سواء أكانت الاتفاقية الأوربية

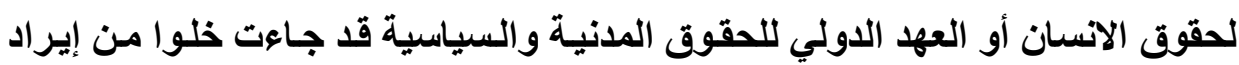
نصوص تضمن له الحقوق المدنية. فقد كان ينظر إلى المرض النفسي باعتباره وصمة اجتماعية ليس من المناسب

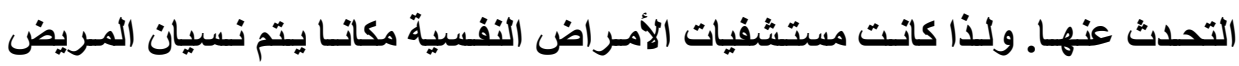
النفسي داخلها ولا محل فيها لمعاملة تتفق مع قو اعد حقوق الانسان. لكن رعايـة المريض النفسي حظيت باهتمـام متزايد على المستوى اللاخلي

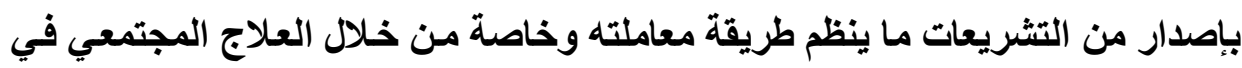
الوسط الحر، أو من حيث تقرير مجموعة من الحقوق لـه عند إيداعه وعند معالجته وعند خروجه. وهو ما سوف نركز عليه في هذا البحث.

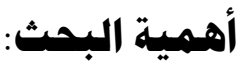

يستمد البحث أهميتهـه مـن طبيعـة المشكلات القانونيـة التـي يثيرهـا معاملـة المريض النفسي ومن التحديات التي فرضتها أخيرا أحداث تمثلت في ارتكاب أفعال خطيرة ارتكبها المرضى النفسيين أو حوادث الانتحار. كل ذلتك أثثار بقوه مناقشات حول فئرل

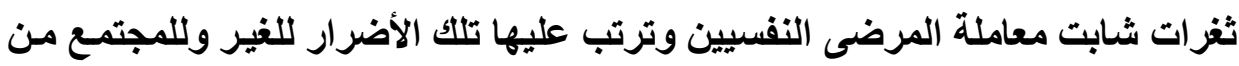


ورائهر. وقد ارتبط ذلك كله برفع دعاوى قضائية بالتعويض وبالمسئولية الجنائية على المسئولين عن مستثفيات الطب العقلي.

كما تبرز أهيدة تلك الدراسة من ظهور قوانين بدأت تعتد بالمضطرب عقليا الذي لا يصل اضطرابه إلى درجة فقدان التمييز أو الحريـة. فقد أصبحت قوانين عديدة

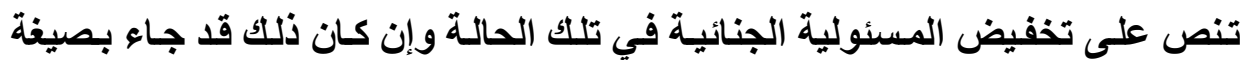

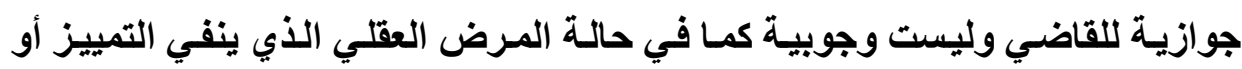

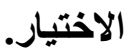

تاريخ الاهتمام بحقوق المريض نفسيا: يرجع الاهتمام بحقوق المريض النفسي إلى عهذ حديث. فلم يتضمن الإعلان

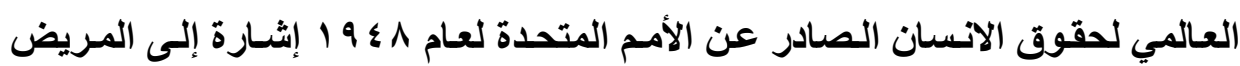
النفسي إلا فيما تضمنه من تحذير من الإيداع غير الإرادي التعسفي في مراكز الطب الطبان النفسي، بالإضافة إلى إثارة إلى حقه في العناية النفسية. ثم كانت المبادئ التي تبتها الأمم المتحدة لحماية الأثخاص المصابين بمرض

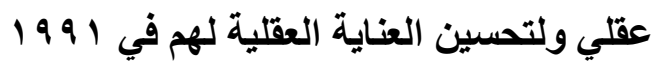

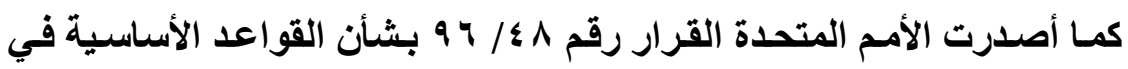
تكافؤ الفرص للأشخاص ذوي الإعاقة اتفاقيـة الأمسم المتحدة في شـأن حقوق المعساقين في ديسمبر 7 . . ب ق قررت مجموعة من الحقوق للمريض النفسي؛ فلم يعد مجرد مريضا لله رعاية صحية ولكنه أصبح صاحب مجموعة من الحقوق 
وعلى المستوى المحلي ، أصدار المشرع المصري قـانون رعايـة المريض

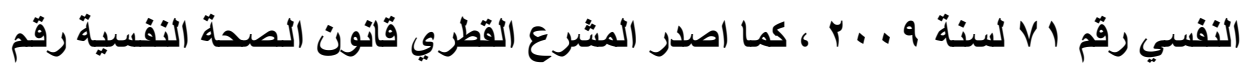

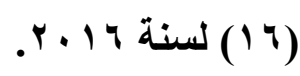

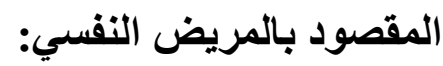
تستخدم القوانين المقارنة تعبير المريض النفسي كمرادف للمريض العقلي. من

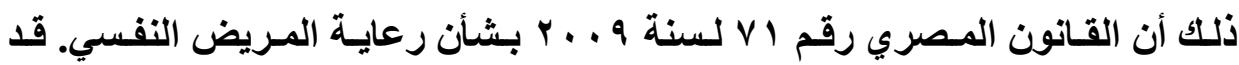

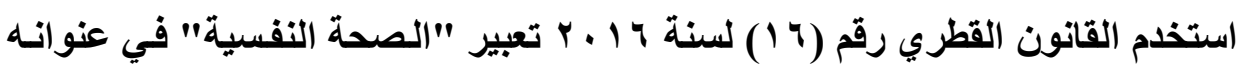

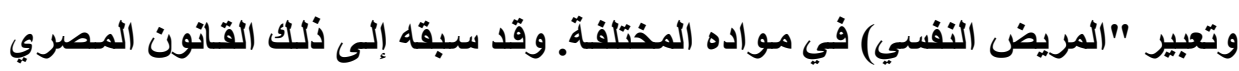
لسنة 9 . . ب باستخدام نفس التعبيرات وهي "رعاية المريض النفسي".

وقد استخدم القانون المصري - في المادة الأولى منهـ تعبير المريض النفسي وليس العقلي. وعرف المريض نفسيا بأنه "الثخص الذي يعاني من اضطراب نفسي

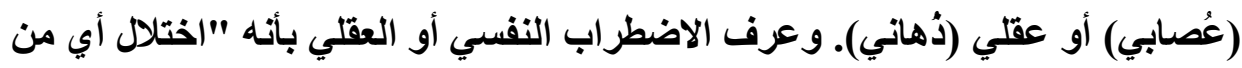
الوظائف النفسية أو العقلية لارجة تحد من تكيف الفرد مع بيئته الاجتماعية، ولا يشمل

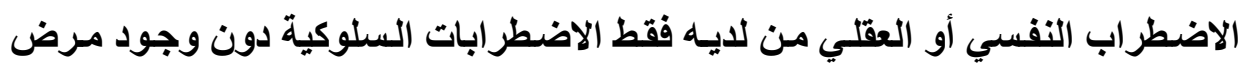
نفسي أو عقلي واضح".

وقد عرفت المـادة الأولى من هذا القانون المقصود بـالمريض النفسي بأنهـ

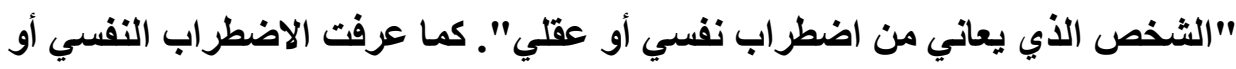

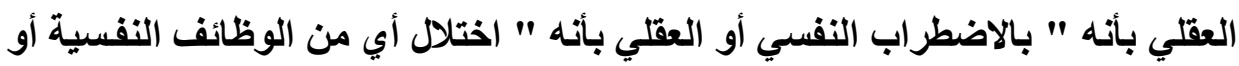

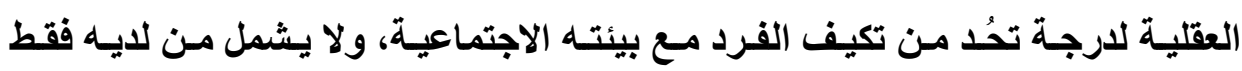
اضطرابات سـلوكية". وحددت مفهوم الصحة النفسية بأنها "حالـة مـن الاستقرار

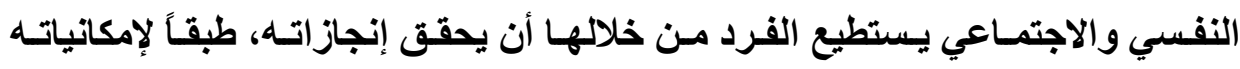


الشخصية، ليتمكن مـن التعامـل مـع الضغوط الحياتيـة العاديـة، كمــــــــيع أن يعمـل وينتج ويساهم في المجتمع".

ومما سبق يتضح أن القوانين تحدث عن المريض نفسيا حيث يقصد المريض عقليـا وليس المصاب بمرض نفسي. ومعروف أن هنـاك فارقا ببين المريض نفسيا والمريض عقليا، هذا الأخير يصاب باضطر اب في ملكاته العقلية. ويرجع السبب في ذلك إلى عدم الرغبة في استخدام تعبير المريض عقليا تجنبا للوصمة التي ترتبط باستعمال هذا الاصطلاح.

\section{المشكلات القانونية}

$$
\text { يثير هذا البحث مشكلات قانونية من أهمها: }
$$

- يف يمكن معاملة المريض النفسي بما يكفل له الكرامة والإنسانية ؟ - - هل يتمتع المريض النفسي بحقوق يشترك فيها مع الانسان غير المريض؟ - - هل للمريض النفسي حقوق يختلف فيها عن المريض العادي؟

- ما هي حقوق الانسان التي يمكن أن يتمتع بها المرض النفسي ؟ - ما هي حدود مسئولية الطبيب المعالج عن الخطأ في معاملة المريض النفسي. - ما هي حدود مسئولية مستثفى الطب النفسي عن الأخطاء التي تنسب إليها؟ - يف يمكن توفير حماية جنائية للمريض النفسي؟

\section{هنهمج البحث:}

اتبعنا في هذه الاراسة منهجا يجمع بين المنهج التأصيلي حيث نرد الفروع إلى أصولها من النظريات العامة سواء في أركان الجريمـة وخاصـة القصد الجنـائي أو في مي مجـال المسئولية الجنائيـة أو المسئولية الطبيـة والمـنهج التحليلي الذي يعتمـد على الثرح والاستشهاد بالأحكام القضائية والاستنتاج. ولم ننس المنهج المقارن الذي فيه 
نقارن وضع القانون المصري في رعاية المريض النفسي بما هو عليه الأمر في قوانين

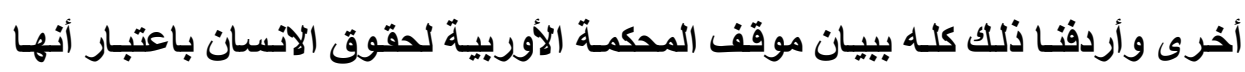
تعالج الوضع في الدول الأوربية الأعضاء فيها.

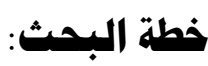
قسمنا تلك الاراسة إلى مبحثين: المبحث الأول: الضمانات المقررة لحمايـة المريض النفسي عند اللخول إلى المى المستثفى أو الخروج منها المبحث الثاني: مدى استفادة المريض النفسي من حقوق الانسان 


\section{المبحث الأول \\ الضهانات المقررة لعماية المريض النفسي عند الدخول \\ إلى المستشفى}

أصبحت التشريعات الوطنية والاتفاقات الدولية تقرر مجموعة من الضمانات

للمريض النفسي تتطلق بلخوله إلى مستثفى الأمراض النفسية؛

$$
\text { المطاب الأول }
$$

\section{الضهانات المقررة في الصور الختلفة لدخول لمريض مستشفى}

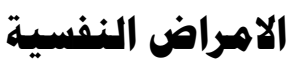

تقرر القوانين المختلفة ومنها القانون المصري والقانون القطري عدة ضمانات

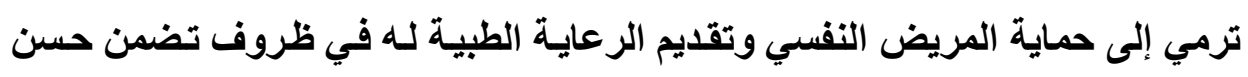

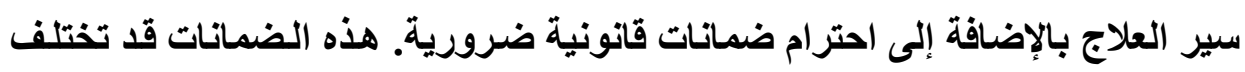

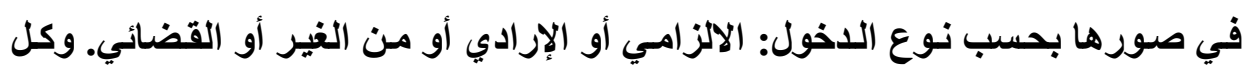
ذلك في إطار من ضرورة الرقابة والتفتيش على المستثفى. أولا-ضمانات الاخول الإرادي لمستثفى الطب النفسي :

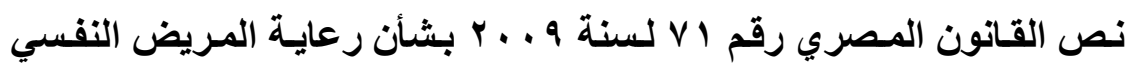

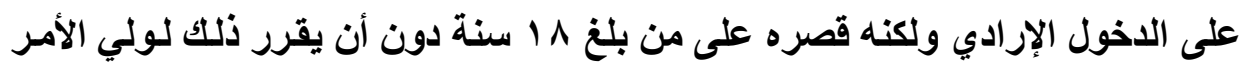

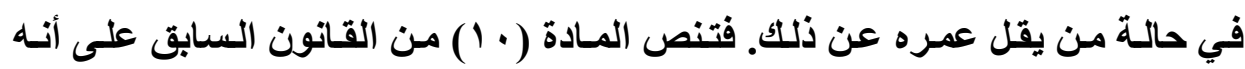

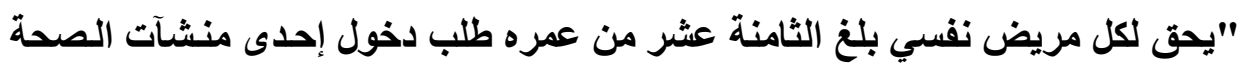


النفسية دون موافقة احد كما يحق له طلب الخروج في أي وقت إلا إذا انطبقت عليه شروط الدخول الإلزامي وفى هذه الحالة تتبع الإجراءات المقررة في هذا الشأن، وفى الثى جميع الأحوال يخطر أهل المريض منى وافق على ذلتك " .

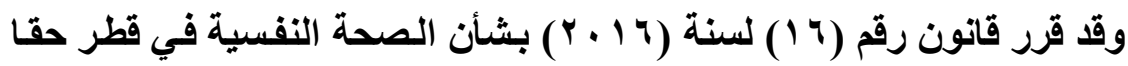
للمريض نفسيا أن يطلب التحاقه بمستشفى الطب النفسي لكي يخضع للعلاج. فتنص

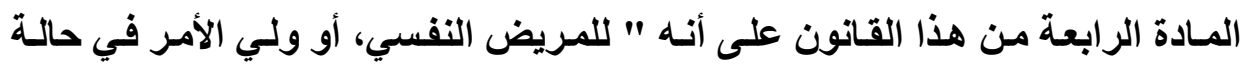

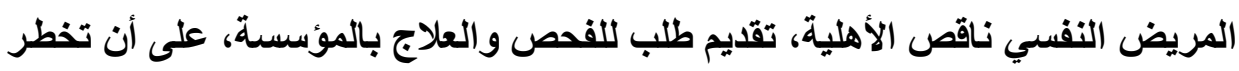

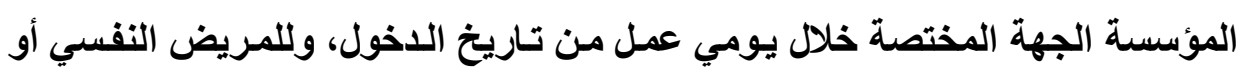

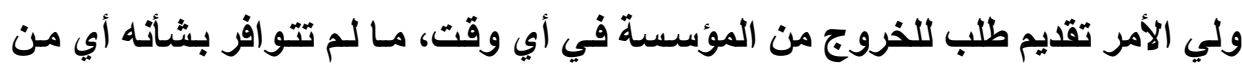

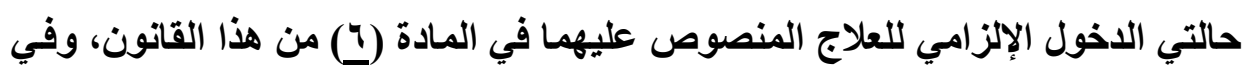

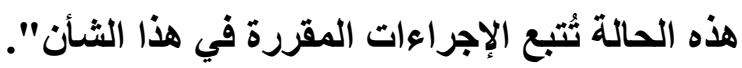

ونحن ننحاز إلى وجهة نظر القانون القطري الذي يجيز لمن قل عمره عن ذلك

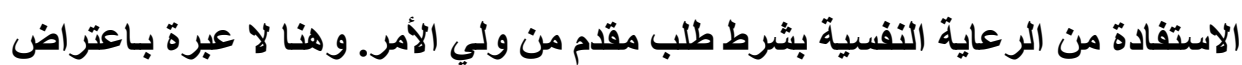
أو عدم موافقة المريض نفسه في حالة تعارض إرادته مع إرادة ولي أمره. ومما سبق يتضح أن هذا النوع من الاخول محاط بضمانات من أهمها:

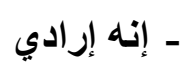

- إن طالب الاخول يجب أن قد بلغ سن الرشد

$$
\text { - يجب أن يعلم بتثخيص حالته }
$$

- يجب أن يتو افر رضاؤه بالعلاج باندلاج 
ـ مـن حق طالب الــخول أن يطلب الخـروج دون تطلب موافقـة شـخص آخـر أو المستثفى أو أي جهة أخرى. ثانياً_ضمانات الإدخال الالزامي للمريض النفسي:

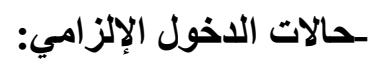

نصت المادة (r ا ) من قانون رعاية المريض النفسي في مصر على اللاخول الإلزامسي بقولهـا "لا يجـوز إدخـال أي شــص إلزاميـا للعـلاج بإحدى منشآت الصحة النفسية إلا بموافقة طبيب متخصص في الطب النفسي وذلكك عند وجود علامات واضحة تدل على وجود مرض نفسي شديا يتطلب علاجه دخول إحدى منشآت الصحة النفسية وذلك في الحالتين الأتيتين: الأولى: قيام احتمـال تدهور شديد ووشيك للحالـة النفسية.

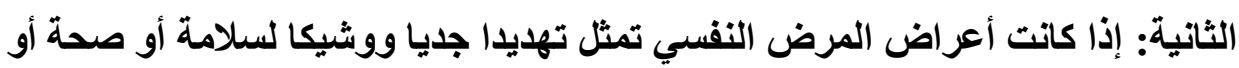
حياة المريض أو سلامة وصحه وحيـاة الأخرين. وفى هـاتين الحسالتين يتعين أن يكون المريض رافضا للاخول المنشأة لتلقى العلاج الللازم على أن يتم إبلاغ الأهل، ومدير المنشأه، ومكتب الخدمة الاجتماعية التابع لله محل إقامـة المريض والمجلس القومي للصحة النفسية أو المجلس الإقليمي للصحة النفسية بقرارات إدخـال المريض إلزاميا

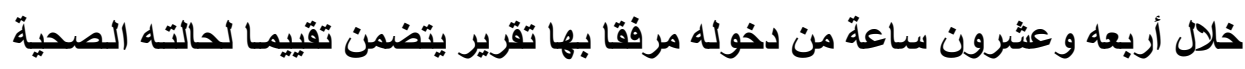
وذلك كله على النحو الأى تحدده اللائحة التنفيذية". كما أجاز قانون الصحة العامـة في قطر الإدخـال الإلزامي للمريض نفسيا في حالـة احتمـال وشـيك للإضـرار بنفسه أو بـالمجتمع أي لتحقيـق مـصلحته أو مـصلحة

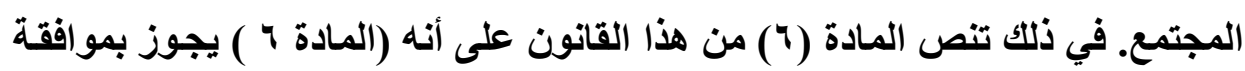

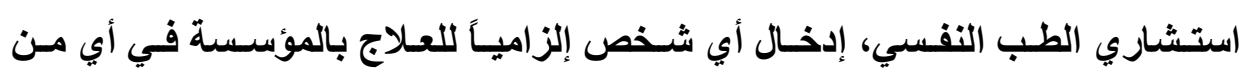
الحالتين التاليتين 
1- إذا ظهرت عليه علامـات واضحة تدل على وجود مرض نفسي شديا يتطلب

علاجه دخول المؤسسة، وكان تدهور حالته الصحية والنفسية محتملاً ووشيكاً

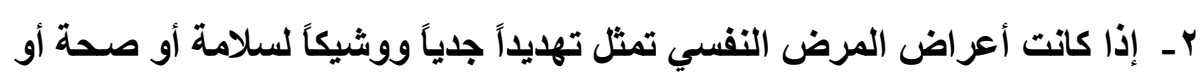

حياة المريض أو سلامة أو صحة أو حياة الآخرين". ـالتمييز بين الحالات العاجلة والحالات غير العاجلة:

يميز القانون المصري بخصوص الاخول غير الإرادي بين الحالات المستعجلة

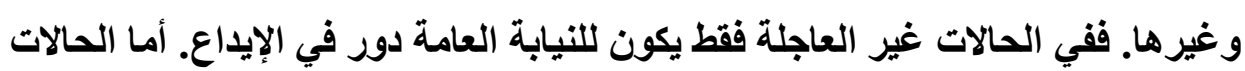
العاجلة فإن القرار بالإيداع يكون إداريا محضا:

(أ) في الحساتل غير العاجلـة يتعين إخطسار النيابـة العامـة التي تتولى الإجراعات.

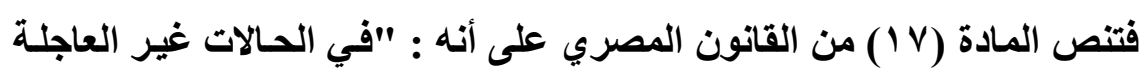
و التي يتعذر فيها إحضار المريض بالوسـائل العاديـة ، يتعين علـي الأشخاص

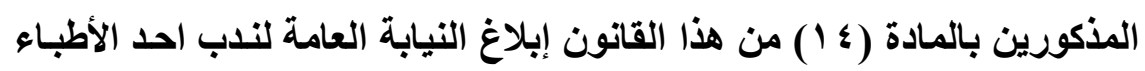

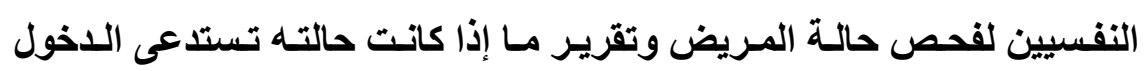
الإلزامي للمنشأة وعرض ذلك على التيابة العامـة والتي لها أن تأمر بنقله إلي مالي

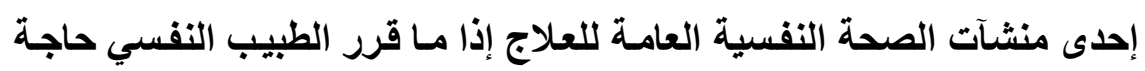

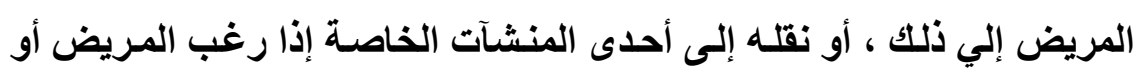

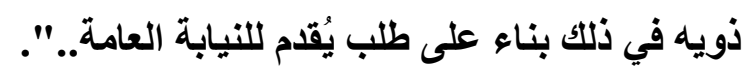
(ب) في الحالات العاجلة يكون لإدارة المستشفى اتخـاذ القرار بالإيـاع مـع ضمانة تتمثل في تقديم تقرير بذلك إلى المجلس الإقليمي للصحة النفسية. فتنص المـادة

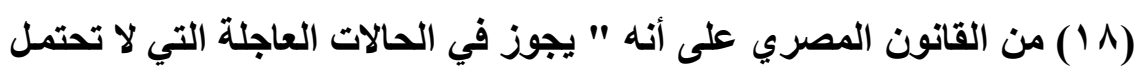

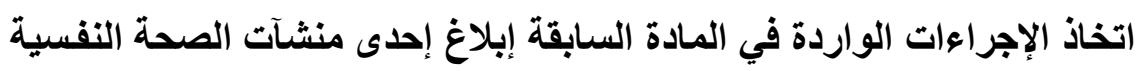


لفحص المريض ونقله للعلاج على وجه السرعة على أن يرفع تقرير للمجلس

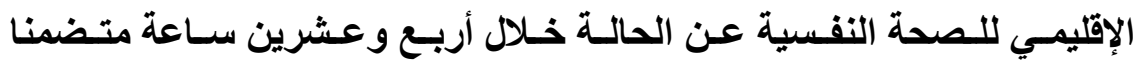
التثخيص المبئي والكيفية التي تم بها نقل المريض والأثخاص الذين قاموا

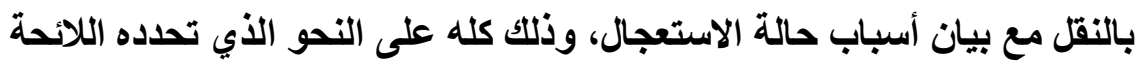
التنفيذية لهذا القانون".

وعلى أية حال فإن الإيداع بقرار إداري يتعين أن يتوافر فيهه نفس الضمانات

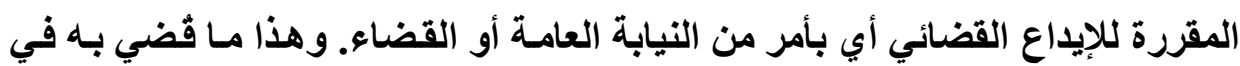

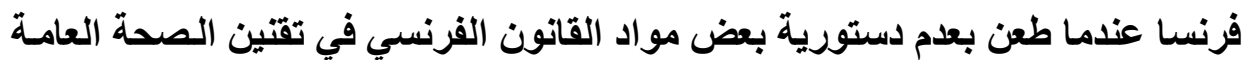

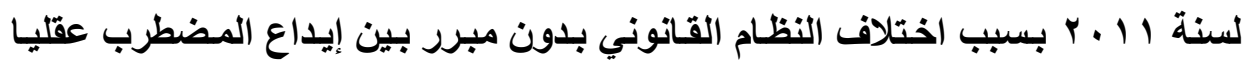

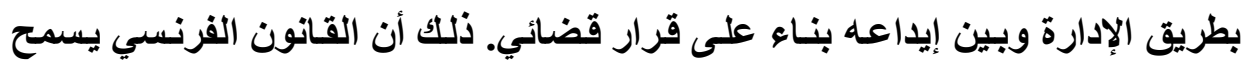

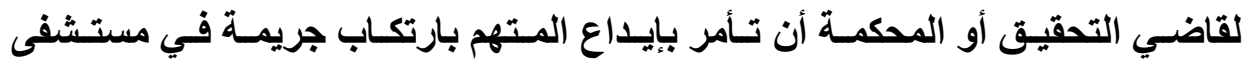

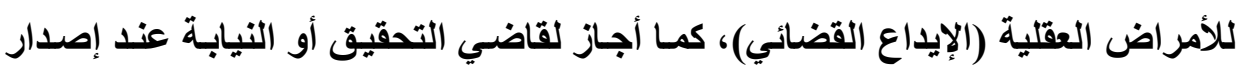

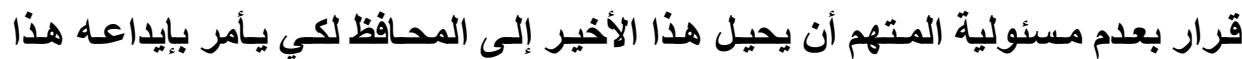
المستثفى (الإيداع الإداري). فقد قدر المجلس الدستوري أن الإيداع الإداري لا يتو افر الفر

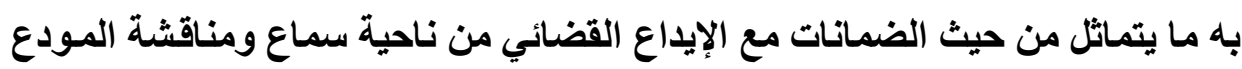

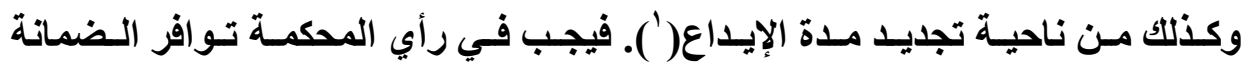
القضائية في كل صورة من صور المعاملة الطبية العقلية بدون رضاء.

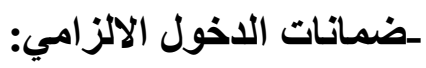

(1) Décision $n^{\circ}$ 2012-235 QPC du 20 avril 2012: https://www.conseilconstitutionnel.fr/decision/2012/2012235QPC.htm 
تقرر القوانين المختلفة بعض الضمانات لمصلحة المريض النفسي عند الاخول

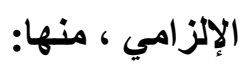

1 - ضرورة صدور الأمر بالاخول من طبيب استثاري للطب النفسي:

كرست المادة (r ا ) من القانون المصري هذا المبدأ بقولها: "لا يجوز إدخال

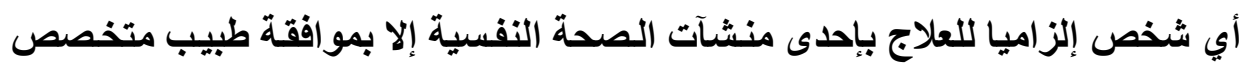
في الطب النفسي وذلك عند وجود علامات واضحة تدل على وجود مرض نفسي شديد يتطلب علاجه دخول إحدى منشآت الصحة النفسية وذللك في الحالتين الأتيتين: الأولى:

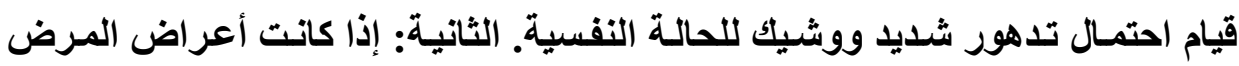
النفسي تمثل تهديدا جديا ووشيكا لسلامة أو صحة أو حيـاة المريض أو سـلامة وصحه وحياة الأخرين. وفى هـاتين الحالتين يتعين أن يكون المريض رافضا لدخول المنشأة لتلقى العلاج اللازم على أن يتم إبلاغ الأهل، ومدير المنشأة، ومكتب الخدمة الاجتماعيـة التابع له محل إقامـة المريض والمجلس القومي للصحة النفسية أو المجلس الإقليمي للصحة النفسية بقرارات إدخال المريض إلزاميا خلال أربعه وعشرون ساعة من دخوله مرفقا بها تقريز يتضمن تقييما لحالته الصحية وذلك كله على النحو الذي تحدده اللائحة

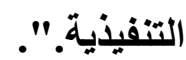

وقد نصت على ذلك أيضا المـادة (") من القانون القطري بقولها: " يجوز بموافقة استثاري الطب النفسي، إدخـال أي شخص إلزامياً للعلاج بالمؤسسة في أي

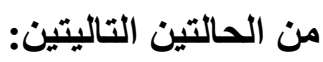
ا - إذا ظهرت عليـه علامـات واضـة تدل على وجود مـرض نفسي شـيا يتطلب علاجه دخول المؤسسة، وكان تدهور حالته الصحية والنفسية محتملاً ووشيكاً 
r - إذا كاتت أعراض المرض النفسي تمثل تهديداً جدياً ووشيكاً لسلامة أو صحة أو حياة المريض أو سلامة أو صحة أو حياة الآخرين

ويتعين في الحالتين المشار إليهمسا، إخطار ولي أمر المريض النفسي ومدير

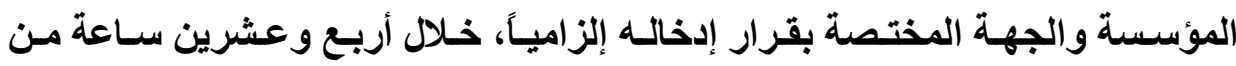
دخوله، على أن يرفق بالإخطار تقرير يتضمن تقييماً لحالته الصحية.". وبالتـالي ليس هنـاك دور لـلإدارة في إصـار أمـر إداري بـدخول شـخص مرغمـا إلى مستشفى الطب

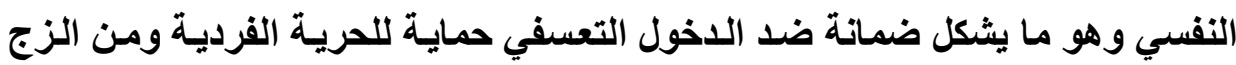
بالأبرياء باعتبار هم مرضى نفسيين. r ـ تشبيب قرار الإيداع:

يجب ان يكون قرار الإيداع الصادر من الجهة الإدارية مسببا. ويتعين توافر تلك الضمانة أيضا في القانون الفرنسي بالنسبة للقرار الصادر من المحافظ و إلاً كان بـاطلا. غير أنـه يكفي أن يحيل القرار في أسبابه إلى الشهادة الطبية بشرط أن تكون تلكـ الشهادة كافية في تثخيص وإيضاح مبررات الإيداع الوجوبي('). فإذا كانت الشهادة مكتوبة على نموذج لكل الحالات ولم تفصح عن الأسباب بشكل دقيق، فإن القرار يكون غير مسبب وبالتالي يكون باطلا(').

(') CE, 21 juilet 1911, Dame veuve Fervel et fils Fervel, rec. 844; Jacques Prévault, note sous CA Lyon, 1er décembre 1988, Consorts Mathieu c. Hôpital psychothérapique de l'Ain et TGI 5 décembre 1988, Mme Ledrut c. Trésor public et autres, D. 1990, p. 268

$\left(^{2}\right)$ CE, 18 oct. 1989, Fransisco, $n^{\circ} 55821$ 
غير أن الأمر شهر تطورا تثريعيا فيمـا يتعلق بتسبيب القرارات الإداريـة التي تنطوي على حرمـان أو تقيبـ للحريـات الفرديـة بحيث لا يجـوز التسبيب عن طريـق

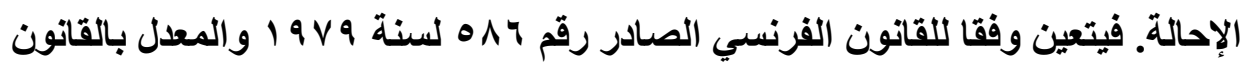

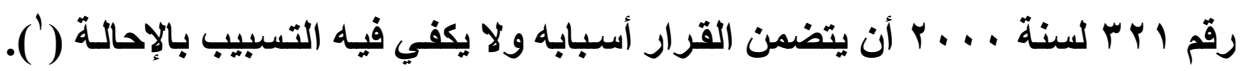
وقد تأكد اتجـاه القضاء الفرنسي في هذا الاتجـاه مـع حكم Deslandes الصادر في

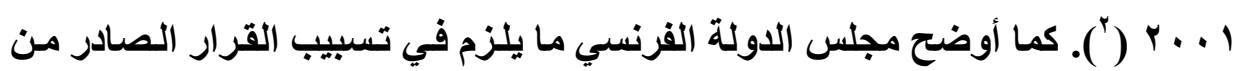
المحافظ بأنه يجب أن يثبت مـا أوردتـه الشهادة الطبية من وقائع ومن أسباب الإيلاع وأن يرفق الشهادة بالقرار ، وإلاً كان الجزاء المترتب هو البطلان(").

وحتى في حالة القرار الطارئ بإيداع شخص في المستشفى فإنها يكون قرارا

قاصر التسبيب إذا استتد إلى أقوال الجيران في خصوص الخطر الذي يتميز به المريض دون إرفاق شهادة طبية بالتشخيص وبالخطورة الحالة) (). في ذلك لا يجوز للقرار أن يستند إلى رأي المريض نفسه بأنه خطر على نفسه أو على الغير( ).

(1) L. $\mathrm{n}^{\circ}$ 79-587, 11 juillet 1979, relative à la motivation des actes administratifs et à l'amélioration des relations entre l'administration et le public modifiée par la loi $L$. $n^{\circ} 2000-321,12$ avril 2000 , relative aux droits des citoyens dans leurs relations avec les administrations

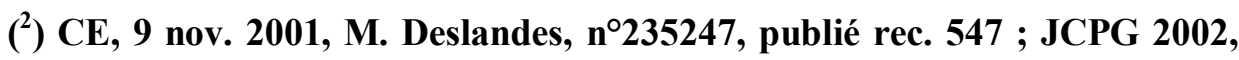
IV, p. 1111, $\mathbf{n}^{\circ} 1963$

$\left(^{3}\right) \mathrm{CE}, 11$ juin 2003, 1ère et 2ème sous-sections réunies, M. Pouzin, n²49086

$\left.{ }^{4}\right)$ TA Paris, 17 janvier 2007, $n^{\circ}$ 0520079/3/2, 0520080/3/2 et 050081/3/2, Mme P. Rigou.

(5) CAA Paris, 17 avril 2007, req. $n^{\circ}$ 06PA01431. 
وإذا صدر القرار باطلا، فإنه وما يترتب عليه ويكون مبنيا عليه يُعد باطلا ـ من

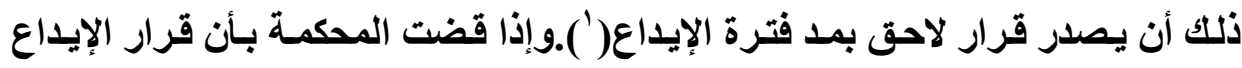
باطل، فإنها تحكم بخروج المريض من المستشفى، سواء أكان القرار منذ صدوره باطلا

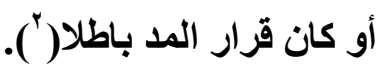

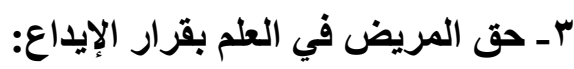

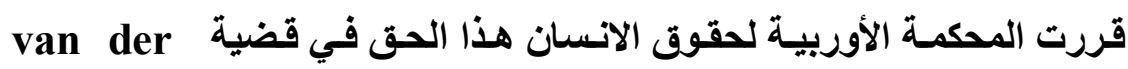
Leer, - - من واجب السلطة المختصة بإصدار قرار الإيداع إخطار المريض به - - من حق المريض العلم بالإيداع

- من حق المريض العلم بالقرار في أقرب فرصة بدون تأخير لكي يمسارس حقه

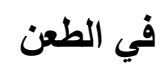
- من حق المريض الاطلاع على الأوراق - يجب على السلطة المختصة سماع المريض إلا إذا ورد بتقرير الاستشاري النفسي عدم جدوى ذلك التكان - - من حق المريض الطعن في القرار أمام القضاء

(') TA Versailles, 10 mai 2006, M. Franck Tobiana, $n^{\circ} 0509551$ et 0510735

${ }^{(2)}$ TA Versailles, ord. Réf., 23 juin 2004, M. Jean-Pierre D. req. $\mathbf{n}^{\circ} 042912$ et TGI Versailles, 25 juin 2004, req. $n^{\circ} 04 / 00069, \operatorname{JCPG~}^{\circ} 5,10015$, note J-H STARK et Ph. Bernardet.

$\left(^{3}\right)$ Cour European de droit de I- homme, Affaire Van Der c. Pays-Bas , $1985, \mathrm{n}^{\circ} 11509$ 
بناء على مـا تقدم قضت المحكمة بمخالفة هولنـا للمـادة (ه ـ ) من الاتفاقية التي تنص على الحق في الحرية الفردية وعدم الحرمان منها إلا في الحالات التي ينص عليها القانون ومنها حجز المريض عقليا بمستشفى الأمراض النفسية ومخالفة الفقرة الثانية من المادة السابقة التي تنص على ضرورة إخطار المريض والفقرة الرابعة التي

$$
\text { ك ـ تـ تأقيت مدة الحق في الطعن ـ }
$$

في ذلك تنص المادة (ף ا () من القانون المصري على أن مدة الإيداع في أولها هي لمدة أسبوع ولا تزيد عن ذلك إلا بشروط بقولها: "لا يجوز إبقاء المريض النفسي إلزاميا بإحدى منشآت الصحة النفسية لأكثر من أسبوع إلا بعد إجراء تقيمين نفسيين للمريض بواسطة أخصائيين للطب النفسي مسجلين للدى المجلس الإقليمي للصحة النفسية المختص بحسب الأحوال أحدهم من خـارج المنشأة والأخر من العـاملين بها على أن يكون أحدهم موظفا حكوميا، وفى كل الأحوال لا يجوز أن يتم التقييم بواسطة أخصائيين يعملان بجهة واحده ويرسل التقيمان إلى المجلس الإقليمي للصحة النفسية خلال سبعة أيسام من استبقاء المريض إلزاميا، ويرفق بهمـا النموذج المستخدم للتلك. وفى حالـة عدم استيفاء هذه الإجراعات في المواعيد المحددة تنتهي حالـة الدخول الإلزامي للمريض، وتتحمل المنشأة ما قد ينجم عن ذلك من آثار. وفى جميع الأحوال تتنهي حالة الاخول الإلزامسي للمريض إذا لم يقتـع المجلس الإقليمي للصحة النفسية بنتائج التقييم النفسي المقدمة إليه وذلك بعد فحص المجلس القومي للصحة النفسية أو المجلس الإقليمي للصحة النفسية له". ويجيز القـانون المصري مـ تلكك المـدة وفقـا للمسادة (9 1 ) مسن جانب الطبيب النفسي التي تنص على أنسه " يجوز للطبيب النفسي المسئول أن يمـد فترة الدخول 
الإلزامي المنصوص عليها في المسادتين ؛ ا وه ا من هذا القانون لمدة شـهر، وذلك

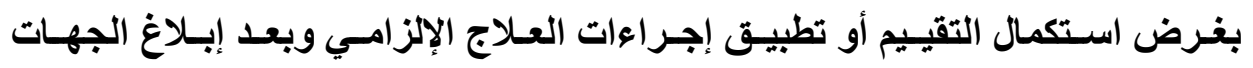
المنصوص عليها فى المادة با من هذا القانون ويجوز مد هذه المدة حتى ثلاثتة أشـهر بعد إبـلاغ المجلس الإقليمسي للصحة النفسية بنـاء على تقريـر يتضمن تقيـيم لحالـة المريض ، والأسباب الداعية لاحتجازه...".

وإذا قدر الطبيب حاجة المريض إلى البقاء مدة أطول، " يكون المد بقرار من المجلس الإقليمي للصحة النفسية لمدد لا تجاوز ستة أثهر وذلك بعد إعادة تقيبم حالة

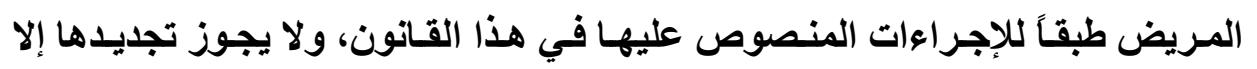
بقرار من المجلس المذكور.".

وفي القانون القطري تنص المادة (V) من القانون على أن تكون مدة الدخول مؤقتة بثلاثة أشهر يجوز تجديدها. فالإيداع ليس دائما. وقد اتبع القانون المصري مبدأ تأقيت العلاج حتى بالنسبة للعلاج في الوسط

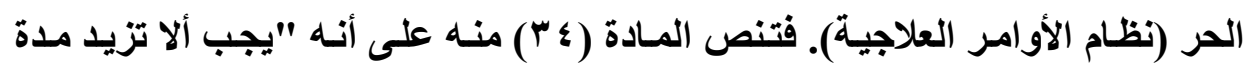
تطبيق نظام الأوامر العلاجية على ستة أشهر ولا يجوز تجديدها لمدد أخرى، إلا بعد إبلاغ المجلس الإقليمي للصحة النفسية وللمجلس الحق بإلغاء هذه الأوامر إذا وجد من الأسباب ما يستلزم ذلك. هـ تقرير الحق في التظلم والطعن في قرار الإدخال: - - - التظلم من قرار الإدخال: -

قرر القـانون المصري في رعايـة المريض النفسي الحق في التظلم من قرار

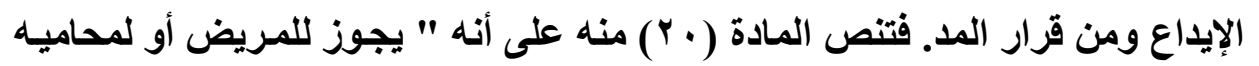
أو لأويـه التظلم من قرارات الحجز أو العـلاج الإلزامس إلى المجلس الإقليمسي للصحة 
النفسية، وللمجلس في هذه الحالة أن يندب خبيراً من خارج المنشأة لفحص الحالة

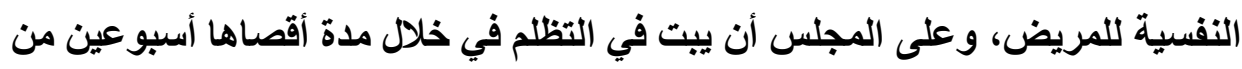

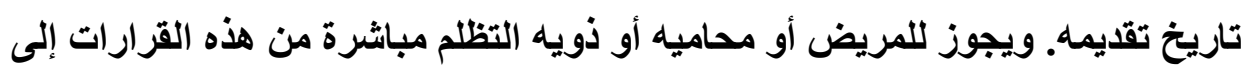

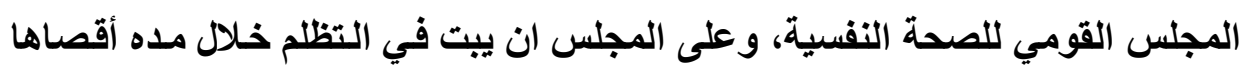

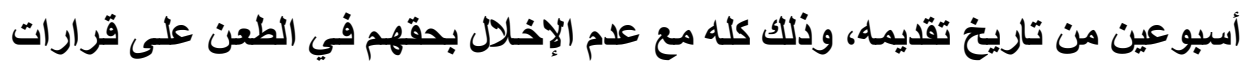

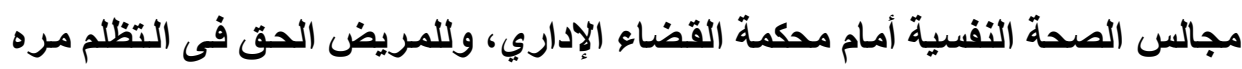

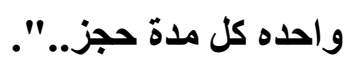

وقد قصد القانون القطري من وراء تقرير هذا الحق حماية المريض نفسيا من

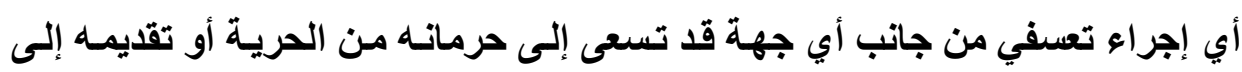

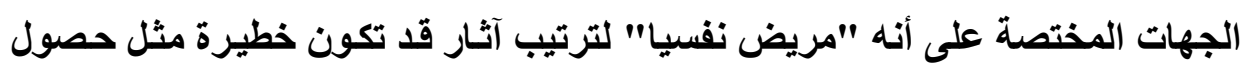

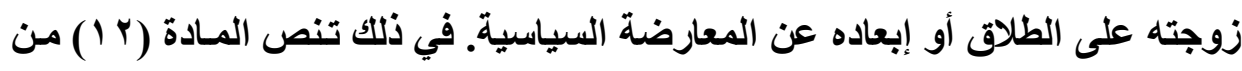

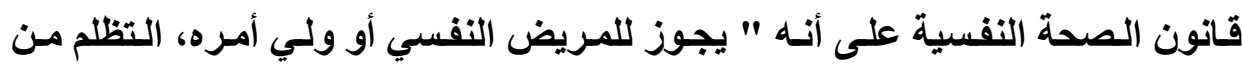

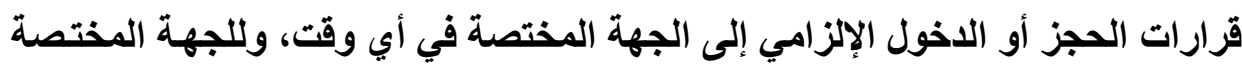

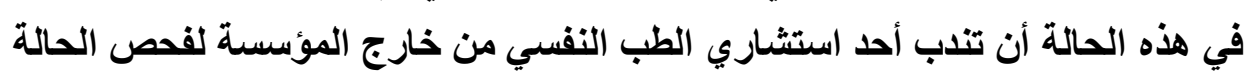

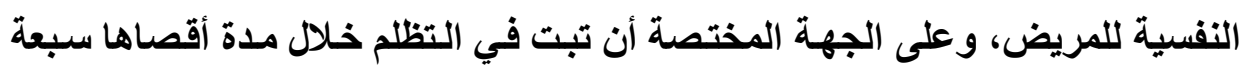

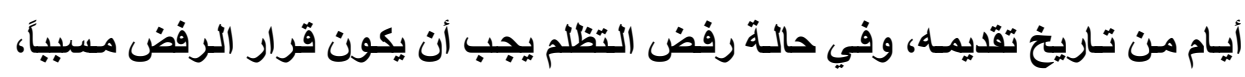
ويكون قرار الجهة المختصة بالبت في التظلم نهائياً".

$$
\text { ويلاحظ على الحق في التظلم في القانون القطري ما يلي: }
$$

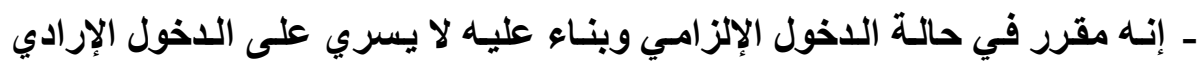

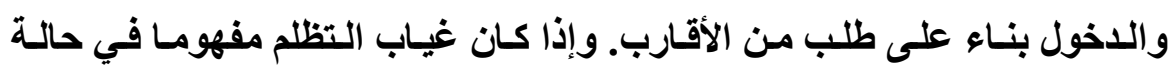

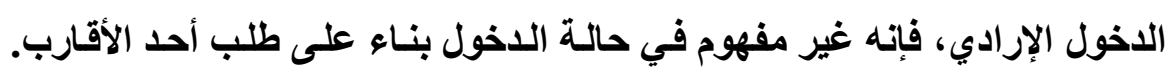

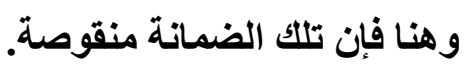


- إن التظلم مقرر للمريض نفسيا أو لولي أمره فقط. وكان من المناسب أن نفتح التظلم لجهات حقوق الانسان التي قد تكتثف وجود حالات للحجز التعسفي داخل

$$
\text { مستثفى الأمراض النفسية. }
$$

- إن القانون لم ينص على الحق في الطعن في القرار الصادر برفض التظلم وذلك

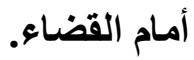

- إن التظلم إداري يحدث أمسام الجهة المختصة. وقد حلدنهاء المسادة الأولسى مـن القانون بأنها " الوحدة الإدارية المختصة بالوزارة". وبالتالي يعيبه عدم توافر الضمانة القضائية أو عدم تقرير الطعن القضائي.

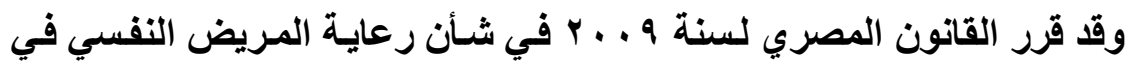
المادة (·r) منه الحق في التظلم وكذلك الحق في الطعن. في خصوص التظلم يكون من

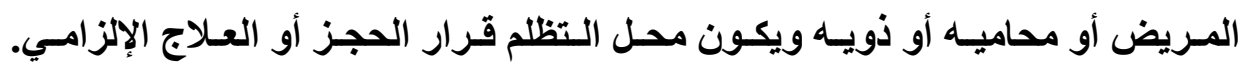

وبخصوص جهة التظلم فإنها تكون أمام المجلس الإقليمي للصحة النفسية.

وعند نظر النظلم يحق للمجلس "أن يندب خبيراً من خارج المنشأة لفحص الحالـة النفسية للمـريض، وعلى المجلس أن يبت في النظلم في خـلال مدة أقصاها

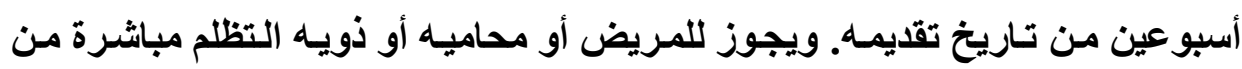

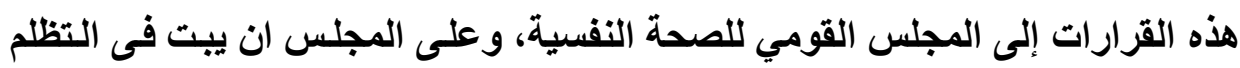

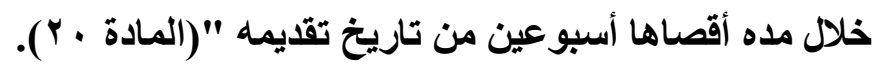

وقد حرصت المادة السابقة من القانون المصري على التأكيد على حق المتظلم في الطعن في القرار الصادر من المجلس بوصفه قرارا إداريـا. وقد حددت المسادة

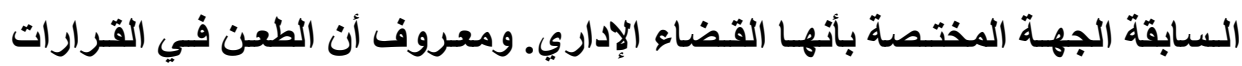
الإدارية هو من اختصاص القضاء الإداري في مصر وفقا للقواعد العامة. 
كما قرر القانون المصري (في المادة 9 1) من قانون رعاية المريض النفسي

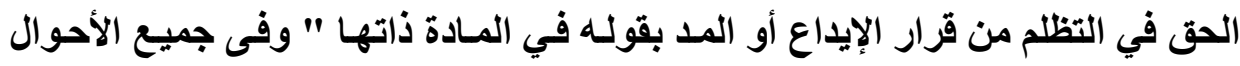

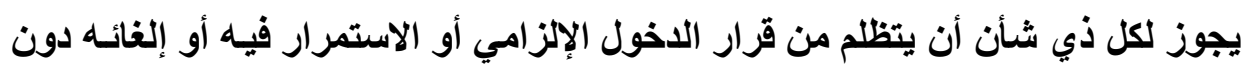

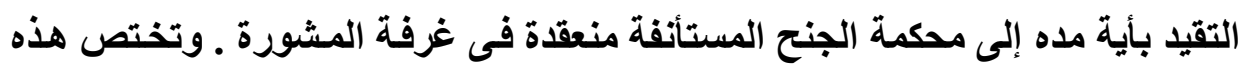

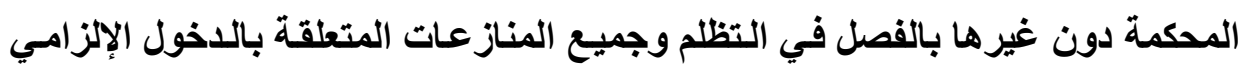
بعد أخذ رأى المجلس الاقليمي للصحة النفسية والنيابة العامة". ويلاحظ أن القانون القطري وإن لم يردد حق المتظلم في الطعن أمسام القضاء،

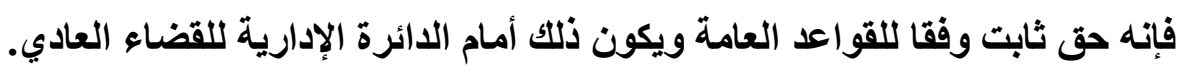
-الجهة المختصة بنظر الطعن في قرار الإيداع:

نظرا لتعلق الأمر بالحرية الفردية، فبان الاختصاص بنظر المنازعات المتعلقة

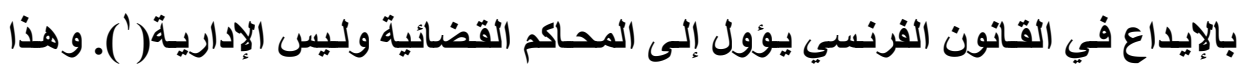

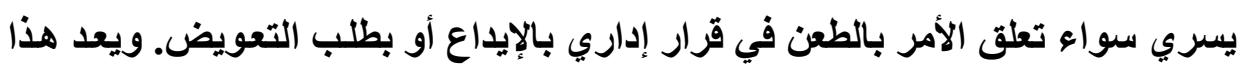

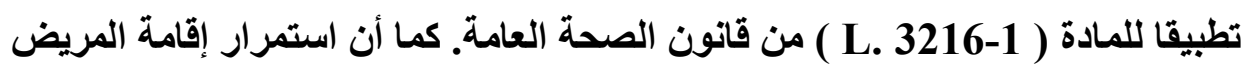

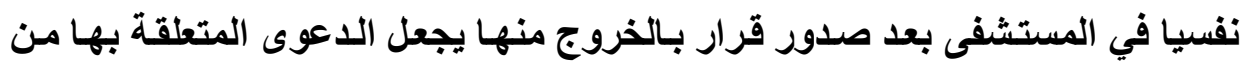

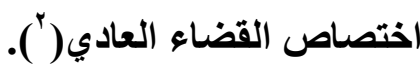

(') T. confl. 17 févr. 1997, Préfet de la région d'Ile-de-France, Préfet de Paris, req. $\mathrm{n}^{0} 3045$, Lebon 524 ; RTD civ. 1998. 72, obs. Hauser, et 181, obs. Normand ; JCP 199 7. II. 22885, concl. Sainte-Rose ; Dr. adm. 1997, no 138, note Paillet ; Gaz. Pal. 1997. 2. 721, concl. Sainte-Rose

$\left(^{2}\right)$ Civ. $1^{\text {re }}, 31$ mars 2010, Agent judiciaire du Trésor c/ $M^{\mathrm{me}} X . \mathbf{n}^{0}$ 0911.803, Bull. civ. I, $\mathbf{n}^{0} 77$; D. 2010. 1259, avis Sarcelet . - Civ. ${ }^{\text {re }}$, 23 juin 2010, M. et $M^{\mathrm{me}} X$., $\mathbf{n}^{0}$ 09-66.026, Bull. civ. I, $\mathbf{n}^{0}$ 141. - Paris, 30 mai 1991, Préfet de police $\mathrm{c} / \mathrm{M}^{\mathrm{me}}$ X. et autres. - Paris, 13 avr. 1999, $=$ 
غير أنه إذا تعلق الأمر بقرار صـادر من المحافظ بـالإفراج عن مريض نفسيا لعدم استمرار أسباب إياعه، فإن الاختصاص يؤول إلى القضاء الإداري باعتباره متعلقا بقرار إداري وغير متضمن سلبا للحرية('). وبالمثل يؤول الاختصاص للقضاء الإداري في خصوص دعوى التعويض عن أضرار تسبب فيها المريض نفسيا بسبب الإفراج

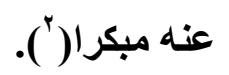

وإذا تعلق الأمر بامتنـاع المحافظ عن اتخـاذ مـا يلزم من تدابير حفظـا لسلامة الآخرين ومن ضـنها إيـاع مريض عقلي بالمستشفى ، فبإن الاختصاص يؤول إلى القضاء الإداري وفقا للقواعد العامة (َّ). وكذلك الطعن على القرار الذي صدر متـأخرا

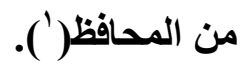

N., D. 2000. 499, note Prévault. - Paris, 14 févr. 2006, K., JCP 2006. IV. 1788. - Paris, 20 oct. 2004, Centre hospitalier spécialisé de Lannemezan, JCP 2005. II. 10087, note Bernardet

(1) T. confl. 26 juin 2006, Président du Conseil de Paris c/ Préfet de police de Paris, req. $\mathrm{n}^{0} 3513$, Lebon 634

(2) CE, sect., 31 déc. 1976, Hôpital psychiatrique de Saint-Égrève, Lebon 583 ; D. 1977. 1991, note Moderne ; AJDA 1977. 135, chron. Nauwelaers et Fabius ; RDSS 1977. 228, concl. Galabert, inf. TA Grenoble, 2 oct. 1974, Dame $V^{\text {ve }}$ Munier, D. 1975. 204, note Moderne ; JCP 1975. II. 18003, obs. Delcourt

$\left({ }^{3}\right)$ l'abstention du préfet (ou éventuellement du maire) à prendre les mesures de sécurité rendues nécessaires par l'état d'un malade mental (CE, ass., 23 janv. 1931, Dame et $D^{\text {Ile }}$ Garcin, Lebon 91 ; DP 1931. 3. 17, concl. Latournerie ; S. 1931. 3. 97, concl. Latournerie, note Bonnard ; RD publ. 1931. 571, concl. Latournerie, note Jèze. - CE 11 juill. 1952, Cts Bruyère, Lebon 375. - CE 20 nov. 1964, Dame Soulaine, $=$ Lebon 567. - CE 13 juill. 1968, Min. Intérieur et Cne de Saulgé c/ Épx 


\begin{tabular}{|c|c|}
\hline أ.د / غنام محمد غنام & العدد WV (سبتمبر I.Y) \\
\hline
\end{tabular}

أما إذا صدر قرار الوضع في مستثفى للأمراض العقلية من المحكمـة عند تقرير عدم

مسئوليته جنائيا، فإنه يعد قرارا قضائيا. وبناء عليه فـإن هذا القرار يقبل الطعن عليه

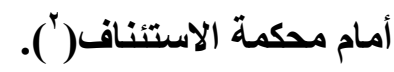

Hugonneau, Lebon 447, inf. TA Poitiers, 6 juill. 1966, Épx Hugonneau, Lebon 774. - CE 26 janv. 1979, Cts Bourgaux, Lebon 29, et, dans la même affaire, CE 26 janv. 1979, Cts Lavaud et autres, RD publ. 1980. 1756. - CE 11 janv. 1985, $D^{\text {lle }}$ Zurecki, req. $n^{0} 33445$. - CE 21 janv. 1991, $M^{\text {me }}$ Bergurand et autres, req. $n^{0} 77259$, RD publ. 1991. 1448. CE14 avr. 1999, Sté Assurances générales de France c/Cne d'Anctoville, req. $\mathrm{n}^{0} 194462$, Lebon T. 1014, Dr. adm. 1999, $\mathrm{n}^{0} 180$, note L. T. - CAA Nancy, 10 oct. 1996, Albrecht et autres, req. $n^{0}$ 94NC01198, LPA 1997, $n^{0}$ 38, p. 18, note Tiffine) ;

(1) CE 10 avr. 1974, Min. Intérieur c/ Épx Jeangrand, Lebon T.1158 ; RD publ. 1975. 526. - CE 22 déc. 1982, Bissery, Lebon 438 ; D. 1984. IR 105, obs. Moderne et Bon ; Quot. jur. 1983, $\mathbf{n}^{0}$ 26, p. 5, note M. D. CE 10 févr. 1984, $M^{\mathrm{me}}$ Dufour, Lebon 59; D. 1986. IR 21, obs. Moderne et Bon ; AJDA 1984. 403, obs. Moreau ; Rev. adm. 1984. 268, obs. Pacteau ; RDSS 1984. 214, note Moderne. - CE 22 avr. 1988, Commissaire de la République du Cher c/ $D^{\text {Ile }}$ Rousseau, Lebon T. 1009 ; D. 1989. Somm. 112, obs. Moderne et Bon ; RD publ. 1990. 552; CE 11 janv. 1985, D $^{\text {Ile }}$ Zurecki, CAA Nancy, 10 oct. 1996, Albrecht et autres

$\left(^{2}\right)$ Crim. 3 févr. 2010, $n^{0}$ 09-82.472, Bull. crim. $\mathbf{n}^{0} 17$; D. 2010. Actu. 585, note Léna ; D. 2010. 942, note Detraz ; AJ pénal 2010. 244, obs. Royer ; Dr. pénal 2010, $\mathbf{n}^{0}$ 52, obs. Maron et Haas ; Procédure 2010, $\mathrm{n}^{0}$ 151, obs. Buisson ; RSC 2011. Chron. 149, obs. Danet 


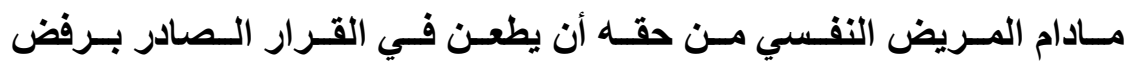

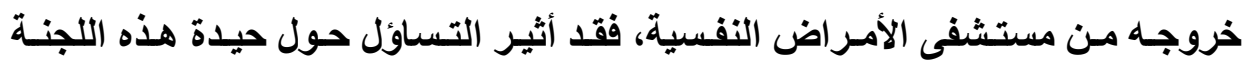

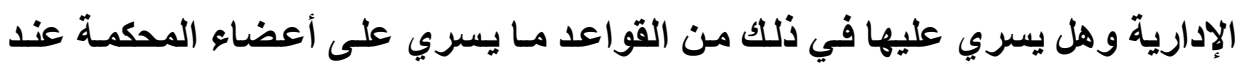

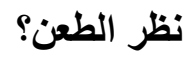

أجابت المحكمة الأوربية لحقوق الانسان على هذا التساؤل بأن اللجنة إدارية ولكنها تلتزم بواجب الحيدة عندما تنظر الطعن في هذا القرار حتى تكون الإجراءات

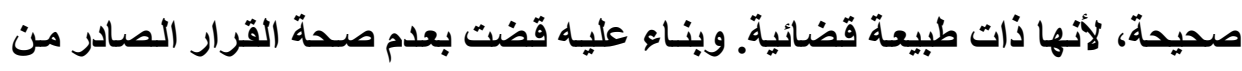

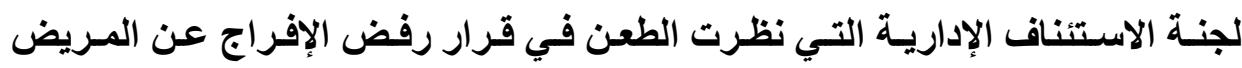

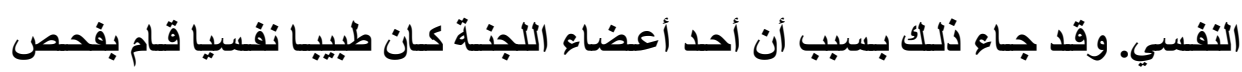

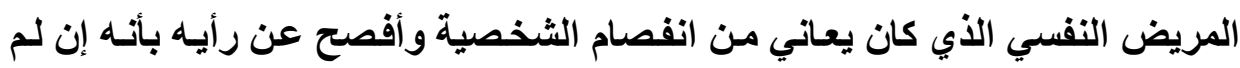
تتحسن حالة المريض فإنه سوف يوصي بعدم الإفراج عنه وقام بتقديم التقرير بهذا المغنى وصدر قرار لجنة الاستنناف الإدارية بناء على ذلكلى ('). وقد جـاء ذلـك تطبيقـا للمـادة 10 ؛ مـن الاتفاقيـة الأوربيـة لحقوق الاتسان

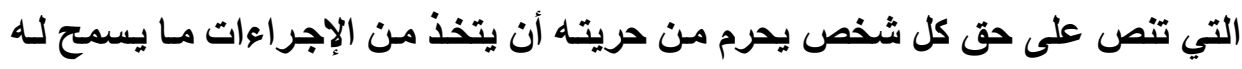

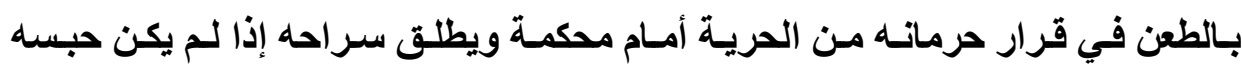
قانونيا.

(1) CASE OF D.N. v. SWITZERLAND, 29 March 2001, (Aplication no. 27154/95) 


$$
\text { ـ التوسع في أصحاب الحق في الطعن: }
$$

تتوسع بعض التشريعات مثل القانون الفرنسي في عدد الأشخاص الذين لهم الحق في طلب خروج المريض من قاضسي الحريـات والحبس. من هؤلاء الطوائف

القيم والوصي والشخص المكلف بحمايـة المريض البـالغ ، زوجها والشخص

الذي طلب إيداعه قبلا ، كل شخص يتلخل في مصلحة المريض ، رئيس النيابة ـ كما أن

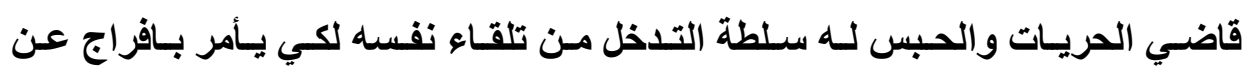

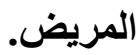

ويجوز الطعن في قرار قاضي الحريات والحبس أمام رئيس محكمة الاستنناف

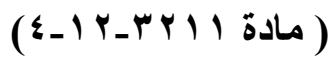

1- أولوية الرعاية المجتمعية للمريض نفسيا على الإيداع في المستشفى:

أجاز القانون المصري في شـأن رعاية المريض النفسي علاج هذا الأخير في

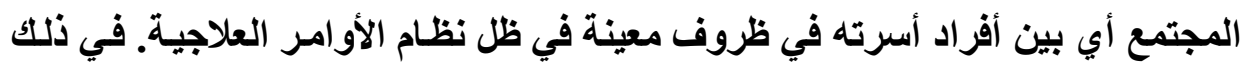

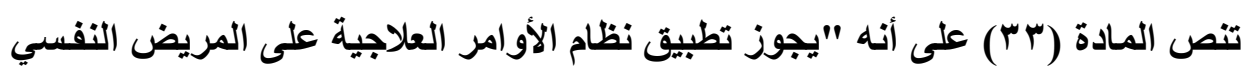

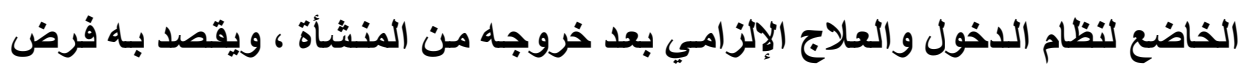

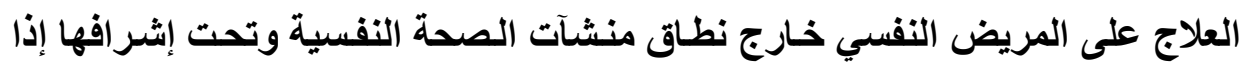
توافرت الثروط الآتية : أ.أن تسمح حالة المريض استمرار علاجه دون الحاجة لبقائه

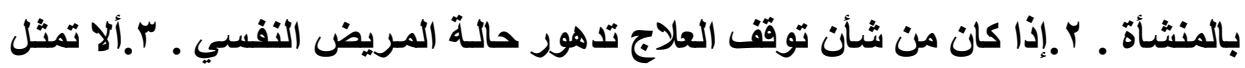
حالة المريض خطراً جسيماً على حياته أو سلامة وحياة الآخرين. ؛. أن يكون للمريض

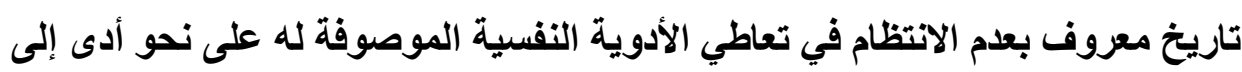

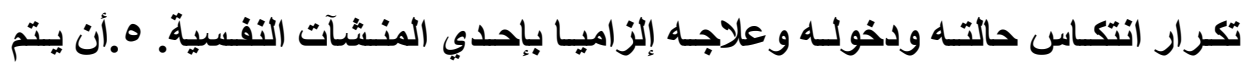


الحصول على تقييم طبي مستقل ـ جأن يتم إبلاغ المجلس القومى للصحة النفسية أو

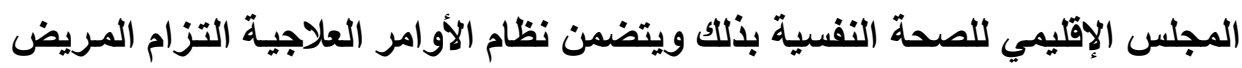

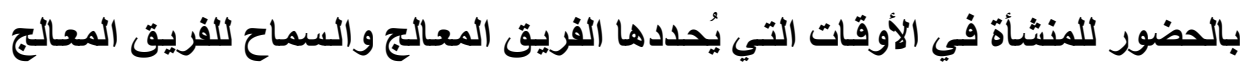
بزيارة المريض في محل إقامته طبقاً للخطة العلاجية المقررة".

كما أتاح القانون القطري للأطباء النفسيين استمرار معالجة المريض نفسيا

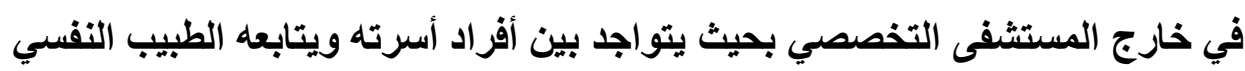

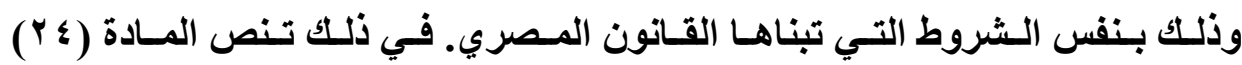

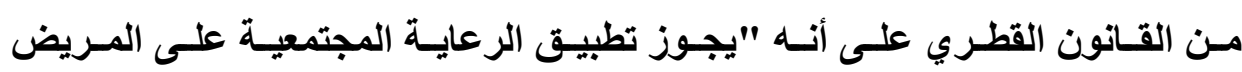

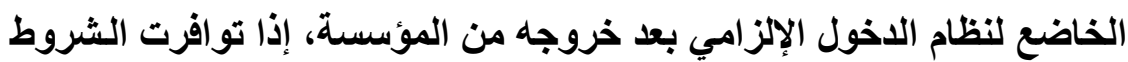

1- أن تسمح حالة المريض باستمرار علاجه دون الحاجة لبقائه بالمؤسسة r- إذا كان من شأن توقف العلاج تدهور حالة المريض النفسي rــ ألا ثُثكل حالة المريض خطراً جسيماً على سلامته أو حياته أو سلامة أو حياة الآخرين \&- أن يكون للمريض تاريخ معروف بعدم الانتظام في تعاطي الأدوية النفسية التي

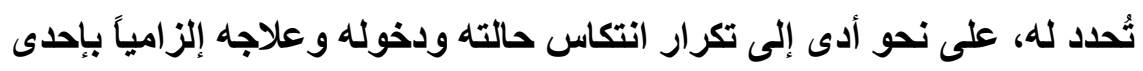
المؤسسات هـ أن يتم الحصول على تقييم طبي مستقل ك- أن يتم إبلاغ الجهة المختصة بذلك 
ويتضمن نظام الرعاية المجتمعية التزام المريض وأسرته بالحضور للمؤسسة

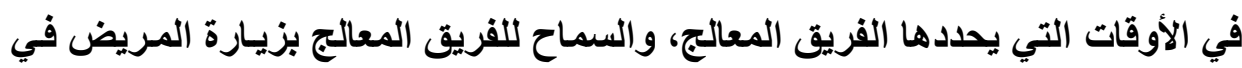

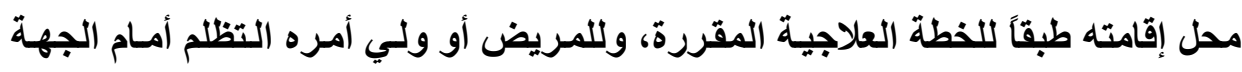

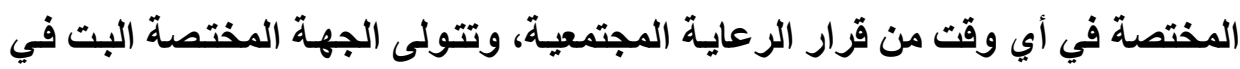
التظلم خلال سبعة أيام من تاريخ تقديمه".

وقد حرصت المسادة (هץ) من القانون السابق على التأكيد على أن الرعايـة

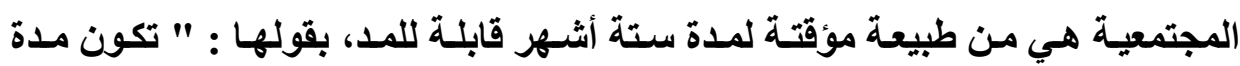

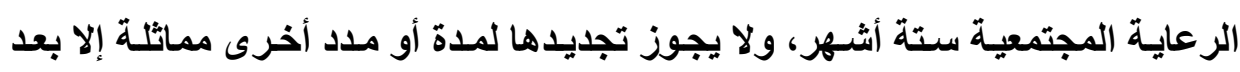
موافقة الجهة المختصة وللجهة المختصة إلغاء الرعاية المجتمعية متى انتفت مبرراتها". V- ضـــانات الإيـاعاع القسري للمـريض نفسيا وفقـا للاتفاقيـة الأوربيـة لحقوق

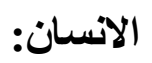

تعرضت اللجنة الأوربية لحقوق الانسان- في قضية A. v. New Zealand لمدى اتفاق أحكام الاتفاقية الأوربية لحقوق الانسان (المسادة 9 (1)) بخصوص حبس الأنس المريض نفسيا بثكل قسري لمدة بلغت تسع سنوات('). وعلى الرغم من طول المدة

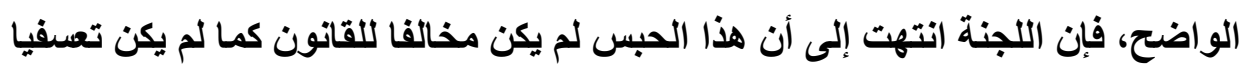
وأنه لا يتعارض مع المادة السابقة بالنظر إلى الاعتبارات التالية: ـ المريض نفسيا كان خطيرا على نفسه وخطيرا على الغير

(1 ) UN, Human Rights Committee, A. v. New Zealand,Communication No. 754/1997 of 3 August 1999 


$$
\begin{aligned}
& \text { ـ كاتت المدة قصيرة ويتم تجديدها بناء على فحص دوري لحالة المريض } \\
& \text { ـ القائمون على الفحص كانوا ثلاثة من كبار المتخصصين } \\
& \text { - مدة الإيداع كان مسموحا بها من جاتب القانون الداخلي } \\
& \text { ـ المريض كان من حقه أن يطعن في قرار المد ( '). }
\end{aligned}
$$

ثالثاـ السماح بلخول المريض نفسيا بناء على طلب أحد أقاربه:

بالإضـافة إلى اللدول الالزامي واللدخول الإرادي نص القانون المصري على هذه الصورة من صور الاخول. بيد أنه قصر الاخول بناء على طلب الأقارب على الولي أو الوصي بقوله في المادة (Y I) على أنه " يجوز لأي من الوالدين أو الوصي أو القيم

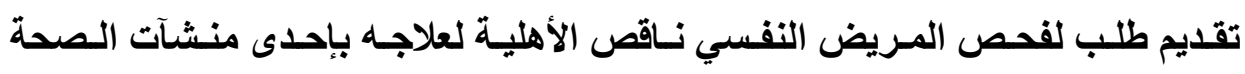
النفسي...". ونتضم إلى موقف القانون المصري لحصر تلكك السلطة فيمن يعبر عن إرادة المـريض عند عدم تـوافر أهليتهـهـ وفـي حالـة عدم تقدم أحدهم بطلب الـدخول وتوافرت حالة من حالات الاخول الإلزامي فإنه يجوز إدخال المريض نفسيا دون طلب

$$
\text { من أحد. }
$$

ويسمح القانون القطري بذلك أيضا طرق اللاخول وذلك عن طريق تبليغ من أقارب المريض أو من ولي أمره. وواضح أن الغرض هنا هو تحقيق مصلحة المريض.

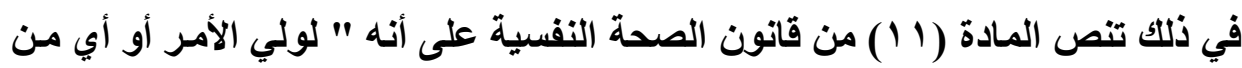
أقارب المريض النفسي حتى الارجة الثانية، أو الجهة المختصة في حالة عدم وجود أي من المذكورين، في الحـالات العاجلة، إبلاغ المؤسسة لفحص المريض ونقله للعلاج

(1) FRA - European Union Agency for Fundamental Rights, Involuntary placement and involuntary treatment of persons with mental health problems, p. 14 
على وجه السرعة...". وواضح أن القانون القطري يوسع من مجال الأقارب الذين من حقهم طلب دخول قريبهم إلى المستشفى.

وهذا ما اتجه إليه القانون الفرنسي إيداع المريض بناء على شخص ثالث ـ بل إنه يوسع أكثر ممن لهم الحق في طلب الاخول. فهو إما قريب أو صديق أو جار أو أي

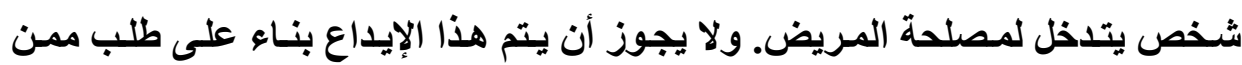

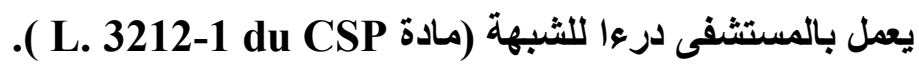
وتتطلب أحكام للقضاء الفرنسي أن يثبت قرار الإيداع بنـاء على طلب الغير العلاقة بين مقلم الطلب و المريض وإلا كان القرار باطلال('). رابعا - جواز الإيداع القضائي للمريض النفسي: يجوز إيداع المريض نفسيا بقرار قضائي من النيابة أو المحكمة. في ذلك تنص

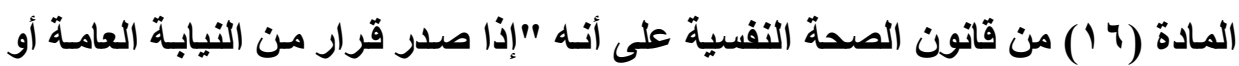

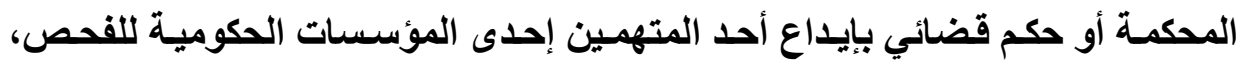

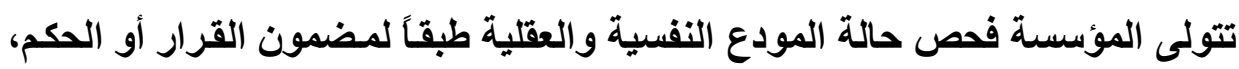
ورفع تقرير بذلك إلى الجهة مصدرة القرار أو الحكم...". وتـــرج التشريعات المقارنـة على جـواز الإذخـال بقـرار مسن النيابـة أو مسن

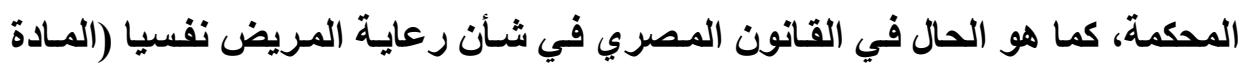

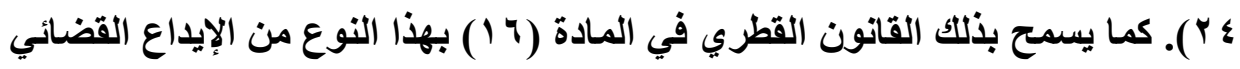
بأمر من النيابة أو بحكم من المحكمة.

(') CAA Douai, 8 nov. 2006, req. $\mathrm{n}^{\circ}$ 06DA00052; TA Melun, 22 février 2007, req. $\mathbf{n}^{\circ}$ 06-7247/2 et $\mathrm{n}^{\circ}$ 06-7248/2; TA Marseille, 3 mai 2007, req. $\mathrm{n}^{\circ} 0608317$, M. G. 
رابعاـ الرقابة على مستثفيات الأمر اض النفسية من ضمانات الإيداع بها: وضـع القـانون المـصري فـي رعايـة المـريض النفسي آليـات للرقابـة على مستثفيات الطب النفسي بسبب أهميتها، وأوكل تلك الرقابة إلى أكثر من جهة: ـ فهنالك أولا المجلس القومي للصحة النفسية ويختص بوضع السياسات الخاصـة بمستشفيات الطب النفسي ومراقبة أحوال دخول وحجز وعلاج المرضى النفسيين والتأكل مـن تمتعهم بالـضمانتات والحقوق المنصوص عليهـا في هذا القـانون ، بالإضافة إلى البت في التظلمـات من قرارات المجـالس الإقليمية للصحة النفسية

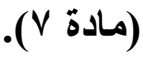
ـ المجلس الإقليمي للصحة النفسية والذي يتكفل بعدة اختصاصات منها : متابعة التقارير الشهرية ونـدب الأطباء المسجلين لديها لفحص المودعين بقرارات أو أحكام قضائية والتفتيش على تلك المستشفيات والنظر في الشكاوى المقدمة من المرضى أو من عائلاتهم، بالإضافة إلى مراجعة قرارات الاخول والعلاج الإلزامي

$$
\text { والأوامر العلاجية (مادة 9). }
$$
ــ للنيابـة العامـة دور في مراقبـة إيـاع المـريض النفسي وذلـك في حالـة الإيـاع القسري ، إذ تنتدب طبيبا متخصصا للتعرف على ضرورة هذا الإيداع (مادة V V). ويلاحظظ أن القـانون القطري لــم يتـضمن نـصوصا تـنظم الرقابـة والتفتيش الدوري على مستشفيات الطب النفسي، الأمر الذي يشكل قصورا يتعين تداركه. وقد اكتفى قـانون الطب النفسي فيها على النص في المـادة (r ب) منـه على أنـه "يكون لمـوظفي الـوزارة، الذين يصدر بتخويلهم صفة مـأموري الضبط القضائي، قرار من النائب العام بالاتفاق مع الوزير، ضبطو إثبات الجرائم التي تقع بالمخالفة لأحكام هذا 
أمسا القانون الفرنسي، فإنه قد أوجب قيـام بعض الجهات بزيـارات لمستشفيات الأمسر اض النفسية. الفـرض مـن تلـك الزيــارات هـو ممارسـة الرقابـة اللازمـة لتلـك الأماكن ( المادة L222-4 من قانون الصحة العامـة). هذه الجهات هي : المحافظ،

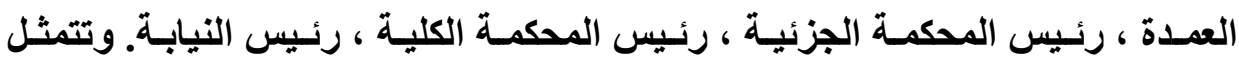
مهمـتهم في : التأكد مـن عدم وجود شـص خـارج الحسالات المسموح بها، مراجعة ظروف المستشفى، التأكد من احترام حقوق المرضى، بالإضافة إلى تلقي الثكاوى عند توافرها.

كمـا أنشأ القانون الفرنسي لجنة خاصـة لمتابعة المستشفيات العقلية في كل

محافظة ( L. 3222-5) تتكون تلك اللجنة من : طبيبين نفسيين يحدد أحدهما رئسيس النيابة لاى محكمة الاستئناف، ويحدد المحافظ الطبيب الثاني ، و عضو قضائي يحدده الرئيس الأول لمحكمة الاستئناف ، وممثلـين للجمعيـات المعتمـدة يحـدهما المحسافظ، وطبيب عـام يحدده المحافظ ـ مهمـة تلك اللجنـة هـي التحقق من كل حالـة من ناحيـة احترام حقوق الانسان والكرامة الانسانية

\section{الاطباب الثاني}

\section{حماية المريض النفسي هن خلال دعاوى المسئولية}

\section{البنائية والمدنية}

ـالمحكمة المختصة بنظر دعاوى المريض نفسيا: لا شك أن تقرير حق المريض نفسيا في الالتجاء إلى القضاء هو من الضمانات المقررة لصالحه. وسواء تعلق الأمر بدعوى المسئولية أو بـدوى إلغاء قرار إداري. وسواء تعلق الأمر باللجوء إلى القضاء الإداري أو القضاء العادي. 
وقد اتجه الرأي في فرنسا إلى أن القاضي الإداري يختص بنظر قرار المحافظ بخروج المريض نفسيا وأن الاختصاص به لا يؤول إلى القاضي العادي، ذلك أن قرار الهار

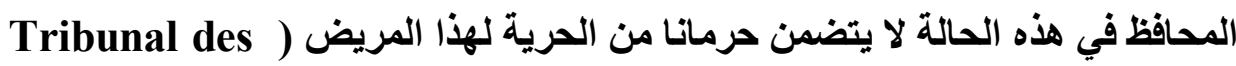
( conflits, décision du 26 juin 2006

وقد سبق أن انتهى القضاء الفرنسي إلى اختصاص القاضس الإداري بنظر

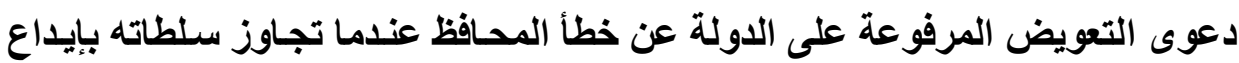
المريض عقليا بمستشفى الطب النفسي('). فإذا تعلق الأمر بدعوى مسئولية، فيان الاختصاص يكون للقضاء الإداري(').

ويأتي هذا القضاء تأكيدا لمـا سبق أن أرسـاه القضاء الفرنسي بـالتمييز في خصوص جهة الاختصاص بين مشروعية القرار الإداري بالإيداع وبين تقدير ضرورة هذا الإيداع والنتائج المترتبة عليه. في الحالة الأولى يؤول الاختصاص الإلى اللى القضاء

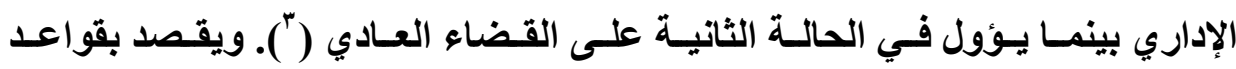
المشروعية ما يتعلق منها بالاختصاص أو بثكل القرار أو الإجراءات.

تطبيقا لذلك قضى مجلس الدولة الفرنسي بـأن القضاء الإداري غير مختص بالنظر في النزاع إذا كان مبنيا على أن قرار الإيداع لم يكن ضروريا بالنظر إلى حالة

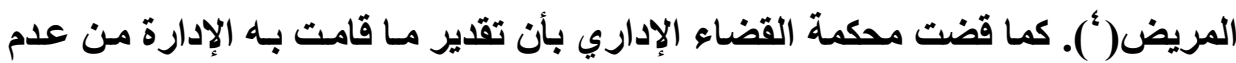

(1) CE, Hôpital psychiatrique de Saint-Egrève, 31 décembre 1976; ; Tribunal des conflits, 30 mars 1992, Préfet d'Ile-etVilaine c. Saulnier)

$\left(^{2}\right)$ CE Ass., 23 janvier 1931, Dame et demoiselle Garcin c. Ministre de l'Intérieur ; CE, 26 janvier 1979, Consorts Bourgaux

$\left(^{3}\right)$ Tribunal des conflits, 6 avril 1946

$\left.{ }^{4}\right)$ CE, 31 juill. 1996, req. $n^{\circ}$ 120736, Mme M. L 
السماح للمريض النفسي باستعمال الهاتف لا يختص به القضاء الإداري بل يختص بـه L. القضاء العادي باعتبار أن الأمر يتعلق بسير الإيداع bien-fondé (وفقا للمـادة 3211-3 الإجراء وليس بشكل الإجراء ومدى مشروعيته. فما يتعلق بحقوق المريض في أثناء إيداعه، فبان ذلك من اختصاص القضاء العادي وليس القضاء الإداري وفقا لما قضى بـه مجلس الدولـة الفرنسي. تطبيقا لذلك قضي بأن نظر التعويض عن عدم إعلام المريض بحقه في الإيـاع في مستشفى آخر

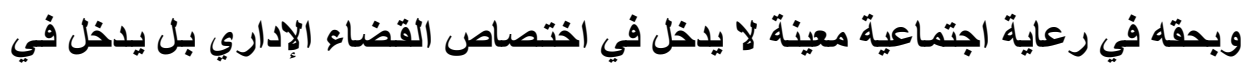

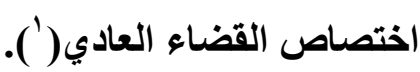
ويلخل ضمن العيوب الإجرائية التي تعيب القرار وتستوجب إلغاءه من جانب

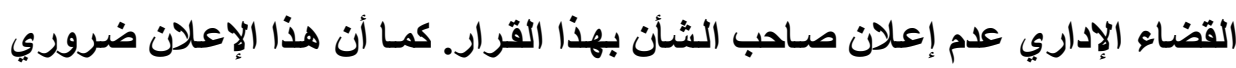
ذللك أنه يسمح لصاحب الشأن بـالطعن في هذا القرار(ّ). هذا الاتجـاه ظهر في أحكام للقضاء الإداري، غير أن مجلس الدولـة اتخذ اتجاهـا آخر حيث قضى بـأن عدم إعلان القرار ليس عيبا فيه ولا يؤدي إلى بطلانه أو مسئولية مدير مستشفى الطب النفسي

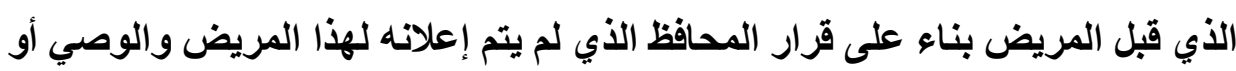

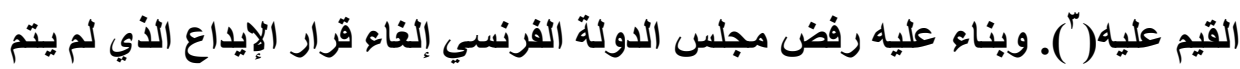

(1) CAA Paris, 21 fév. 2006, req. n02PA02087

$\left(^{2}\right)$ TA Dijon, 5 janvvier 1993, Grare, $n^{\circ} 88-944$ et 88-953 ; TA Marseille 23 février 1993, Mme X, TA Paris 5 janvier 1994, Nollet ; CAA Paris, 25 mai 1999, Gaudel, $n^{\circ}$ 96PA02212

(') CE, 3 novembre 1997, M. Granata, n 146447 
إعلانـهـ إلى صـاحب الشأن('). ونفس الأمر يقال بالنسبة لدعوى التعويض عن عدم

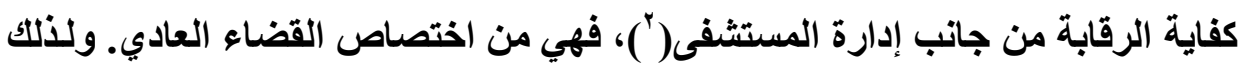
قضي بـأن الاختصاص بنظر دعـى التعويض عن انتحسار أحد المرضسى النفسيين المستتدة إلى نقص في الرقابة يؤول إلى القضاء العادي وليس القضاء الإداري(ّآ ). وكذلك الأمر بالنسبة للاعاوى المتعلقة بالزيارات للمريض()؛ أله وهذا مـا أيدته المحكمة الأوربية لحقوق الانسان()

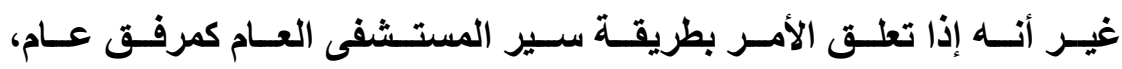
فـإن الأمسر يتعلـق بطريقـة سـير المرفـق العسام ويجعل دعـوى التعـويض المرفوعـة عن الوضـع فـي عزلـة للمـريض (فـي غرفـة دون اتصـال بـالآخرين ) مسن اختصاص القضاء الإداري("). فالأمر يتعلق بالكرامة الإنسانية وليس بالحريـة الفرديـة وفقا لهذا

القضاء.

(1) CE, Sect. 1er avril 2005, Mme L., n²64627; CAA Paris, 2 juin 2005, req $n^{\circ}$ 04PA03714 ; CAA Paris, 21 fév. 2006, req. n $^{\circ} 02$ PA02087 ; CAA Bordeaux, 26 déc. 2006, req. ${ }^{\circ}$ 04BX01278

$\left(^{2}\right)$ CAA Douai, 12 juillet 2001, 1ère ch., req. $\mathrm{n}^{\circ}$ 98DA00428; CE, 4 oct. 1967, Hittler, rec. 735, cité par Claire Landais p. 416.

$\left(^{3}\right)$ CAA Douai, 12 juillet 2001, 1ère ch., req. $n^{\circ} 98 D A 00428$

$\left(^{4}\right)$ CE, 3 mars 2003, $n^{\circ}$ 254625, Centre hospitalier spécialisé de Sarreguemines

(5) CE, 27 nov. 2003, $n^{\circ}$ 261947, Association française contre l'abus psychiatrique

(') CAA Paris, 23 mai 2000, req. $n^{\circ}$ 97PA03276. 


\section{نوع الخطأ الموجب للمسئولية عن العلاج الطبي النفسي:}

من القواعد الاستورية مـا قضى بـه المجلس الدستوري الفرنسي من التزام

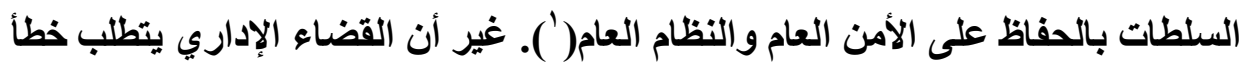

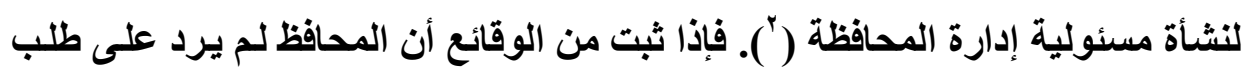

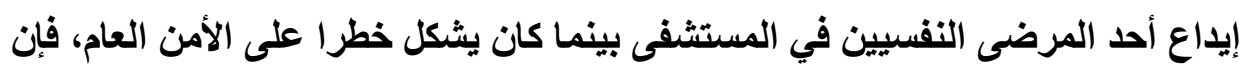

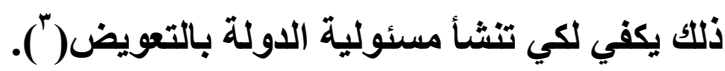

وقد تطورت أحكام القضاء الفرنسي في أحكامه عندما لم يعد يتطلب خطأ مرفقيا

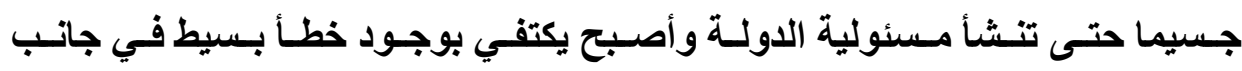

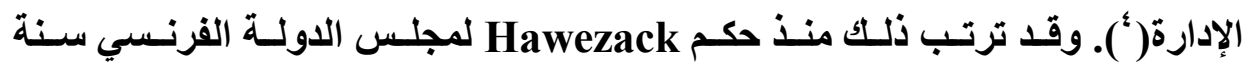

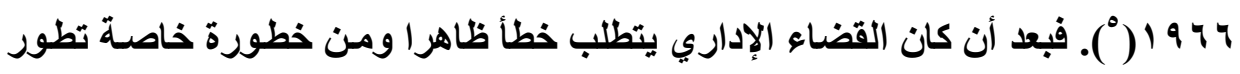
لكي يتطلب خطأ جسيما ثم انتهى به المقام لكي يكتفي بالخطأ اليسير(").

(') $\mathrm{CC} \mathrm{n}^{\circ}$ 82-241 du 27 juillet 1982, Recueil des décisions p. 48

$\left.{ }^{2}\right)$ CE, 26 janv. 1979, $n^{\circ}$ 99511, M. et Mme. Z. et deux décisions semblablesdu même jour : Consorts Scheid, 99881 et Consorts Lavaud et autres, 99910

$\left(^{3}\right)$ CE, 13 janv. 1971, $n^{\circ}$ 80251, Sieur Planchon

$\left.{ }^{4}\right)$ CE, 14 avril 1999, Sté AGF : Dr. Adm. 1999, comm. N 180 ; JCP 2000, I, 213, chron. J. Petit et C. Boiteau.

(5) Hawezack, Rec. CE, p. 6, D. 1966. 317, note F. Moderne)

(') CE, ass., 10 avr. 1992, M. et Mme V., Rec. CE , p. 171, concl. H. Legal, D. 1993, somm. 146, obs. P. Bon et P. Terneyre, JCP 1992. IV. 1695, obs. M.-C. Rouault, et 1992. II. 21881, note J. Moreau, Petites affiches 3 juill. 1992, $\mathbf{n}^{0} 80$, p. 23, note V. Haïm, RFD adm. 1992. 571, concl. $=$ 


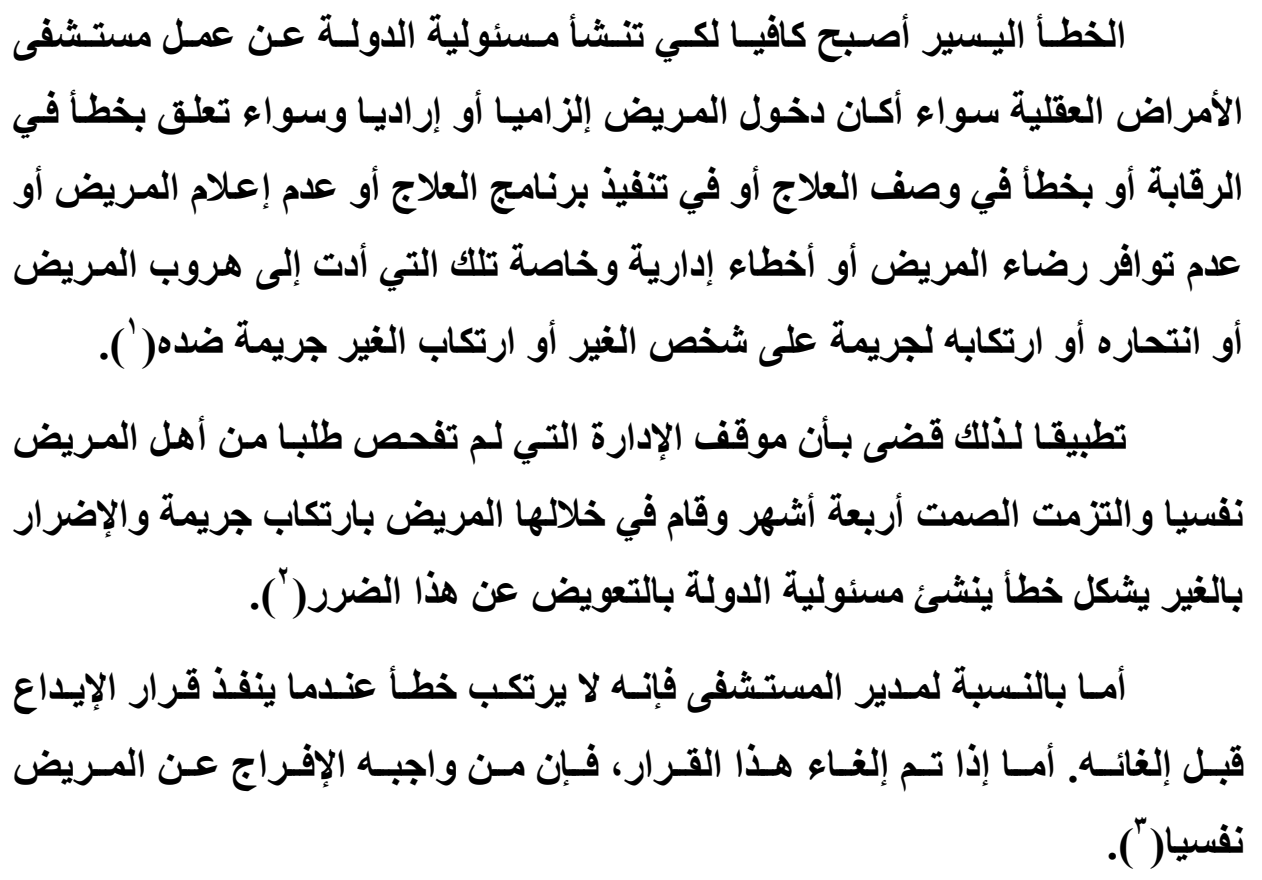

Legal, AJDA 1992.355, concl. Legal, Rev. adm. 1993. 561, note P. Fraissex

(') ., CE 5 mars 1975, Dame Moulis, Rec. CE, p. 177, RD sanit. soc. 1975. 514, obs. F. Moderne ; 16 avr. 1980, Ghelaf, Rec. CE, tables, p. 890, RD publ. 1980. 1761, D. 1980, IR 505, obs. F. Moderne et P. Bon, RD sanit. soc. 1981. 79, obs. J.-M. de Forges ; 27 févr. 1985, CHR de Tarbes, Rec. CE, tables, p. 767, RD publ. 1985.1372, obs. Y. Gaudemet ; CAA Paris, ${ }^{\text {er }}$ juill. 1997, Bourguignon, Dr. adm. 1998, $n^{0}$ 88, note C. Esper

(') CAA Paris, 8 nov. 2006, ${ }^{\circ}$ 04PA00834, M. Giovanni X.

$\left({ }^{3}\right)$ CE, 5 juin 1996, M.P. c/ Centre hospitalier spécialisé de Lehon 
ولا يسأل المركز الطبي أو المستثفى أو حتى المحافظ عن عدم إيداع المريض إلا إذا توافرت من الدلائل أو تقرير طبية تدعو إلى ضرورة إيداعه بسبب مـا يشكله من التهن

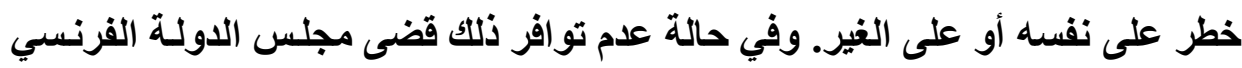

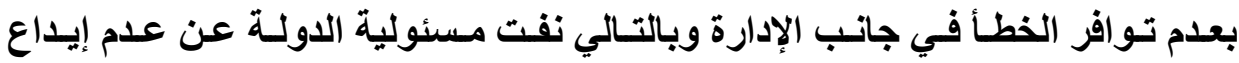

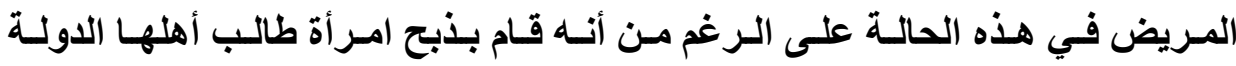

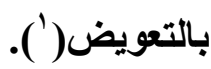

للمحافظ أن يأمر بخروج المريض نفسيا بعد إيداعه بناء على طلب وفقا للمسادة من مدير مستشفى الأمراض النفسية ( L. 3211-12 CSP ) أو طلب من اللجنة

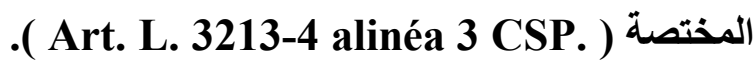
على العكس من ذلك يرتكب طبيب المستشفى في حالة الإفراج عن المريض خطأ إذا وافق على ذلك طالبا تأكيد تثخصيه للحالة من طبيب آخر ودون انتظار ورود

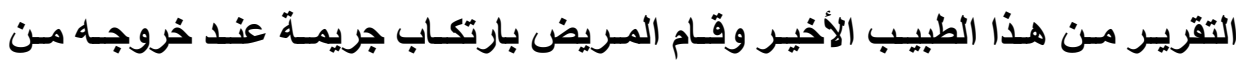

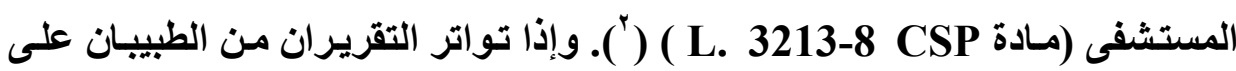

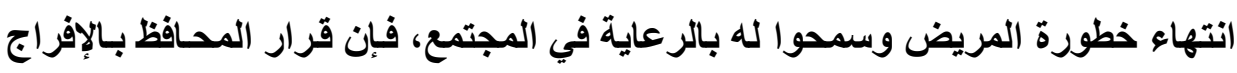
لا يكون مخطئا ولا يتولد عنه نثوء مسئولية الدولة بالتعويض.

وواضح أن عدم تطلب القضاء الإداري للخطأ الجسيم من شـأنه أن يقدم حماية

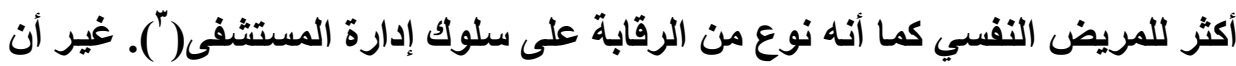

(') CAA Bordeaux, 4 septembre 2007, $\mathrm{n}^{\circ} 04 \mathrm{BX01852}$

$\left(^{2}\right) C E$, section, 31 déc. 1976, Hôpital psychiatrique de Saint-Égrève Isère, $n^{\circ} 97517$, rec. 584

$\left(^{3}\right)$ CE, ass., 10 avril 1992, Epoux V., rec. p. 171. 
الاستشاري النفسي عذدما يدلي برأيه في تثخيص الحالة يمكن أن يرتكب خطأ يترتب

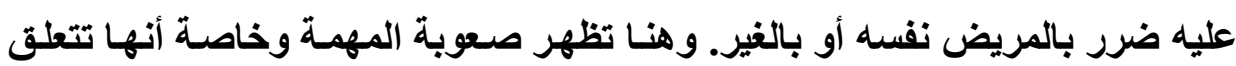
برأي يمكن ان يختلف فيه الأطباء النفسيون.

من ضمن الأخطاء التي قضى مجلس الدولة بتو افر من جانب المستثفى الطبي

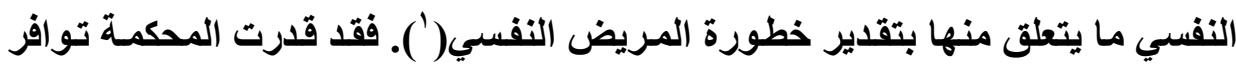

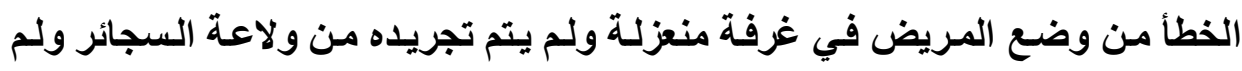

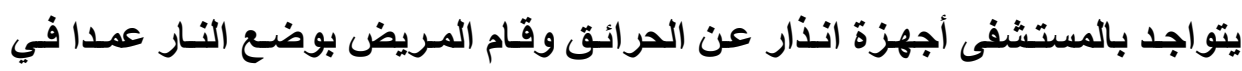

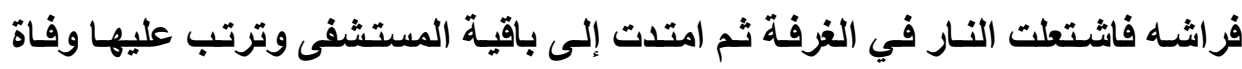

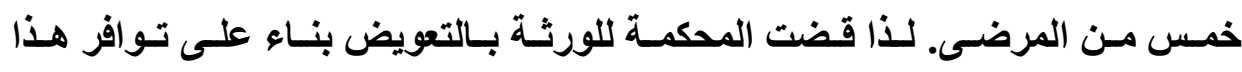
الخطأ()). وكاتت المحكمة الجنائية قد قضت بمسئولية رئيس الأطباء المناوب ومسئول

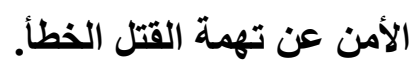

كما قضى بتو افر الخطأ من واقعة أن القائمين عليها لم يقوموا بتتبيه رب العمل الذي تقدم للعمل في شركته أن المريض قام بالحريق مرتين.

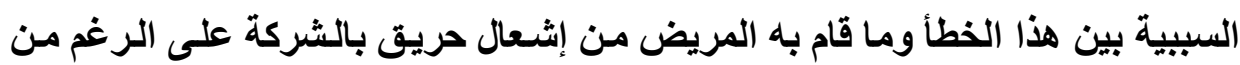

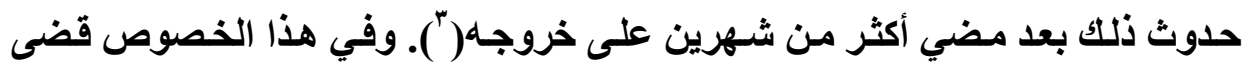

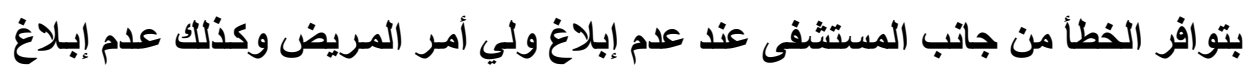

(1) CE 23 juin 1986, CHS de Maison-Blanche, Rec. CE, tables, p. 712, D. 1987, somm. 113, obs. F. Moderne et P. Bon, RD publ. 1987. 465, obs. Y. Gaudemet

$\left(^{2}\right)$ CAA Nantes, 28 décembre 2006, req. n $^{\circ} 06 \mathrm{NT} 00991$.

$\left.{ }^{3}\right) \mathrm{CE}$, sect, 30 juin 1978, req. $\mathrm{n}^{\circ} \mathbf{9 8 9 4 0 0 4 9 8 5}$ 


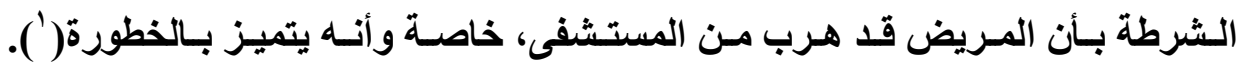
ويختلف الأمر لو أن المريض تلقى العلاج بالمستشفى وأوضحت تقارير الأطباء أن

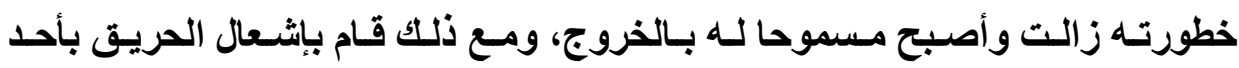
المنازل، فإن الخطأ ينتفي في جاتب إدارة المستثفى(').

ومن المؤكد أن القائمين على أمور المريض يلتزمون بالسر الطبي. وبناء عليه

قضى بأن الممرضة التي تكشف لأحد الأشخاص عن تثخيص أحد المرضى بالمستثفى تخالف الالتزام بالسر المهني. وينـاء عليه قضى بـأن من حق الإدارة أن توقع عليها

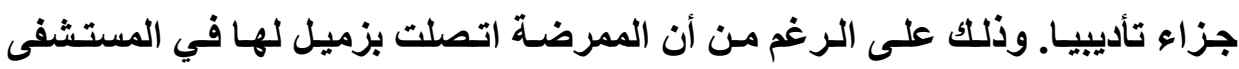

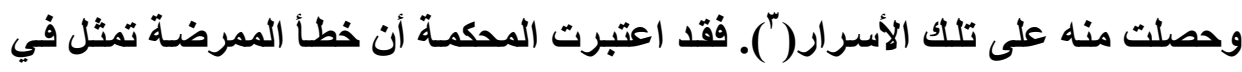
نشر تلك الأسرار خارج المستثفى.

هذا بالنسبة للخطأ المنسوب إلى إدارة المستشفى أو أحد العاملين بها عن خطأ سبب ضررا للمريض وقد وقع هذا الخطأ بداخلها. أما إذا تعلق بضرر وقع على شخص في خارج المستثفى بسبب خطأ منسوب إلى المريض الأي سمحت له المستثفى بتلقي

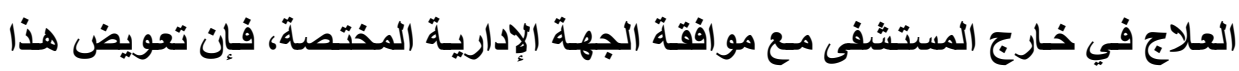

(') CE 10 déc. 1982, CHR du Havre, Rec. CE, tables, p. 741, D. 1984, IR 109, obs. F. Moderne et P. Bon ; V. C. JONAS, La réparation des dommages causés aux tiers par les malades mentaux : évolution et perspectives, RD sanit. soc. 1990.1

(') Conseil d'Etat, SSR., 14 avril 1999, Société assurances générales de France, requête numéro 194462

$\left(^{3}\right)$ CAA Nancy, 24 février 2005, req. $n^{\circ} 00 N C 00430$. 


\section{الضرر الذي تسببه المريض للغير لا يستلزم خطأ ولكن يبنى على أسـاس المخاطر('). وذلك على الرغم من أن القضاء يعترف بشرعية العلاج في الوسط العائلي('). بيد أن الغير لا يطالب بتحمل الضرر الناتج عن خروج المريض إلى الوسط الصر. وقد ينسب الخطأ إلى إدارة من إدارات الدولة غير مستثفى الأمراض النفسية. تطبيقا لذلك قضي بمسئولية الدولة بالتعويض المرفوعة على العمدة بسبب تراخيه في إخطـار المحسافظ عـن شـخص خطير بـسبب اضـطر ابه العقلـي(") وأن الدولـة تلتـزم بالتعويض بسبب الإفراج عن مريض نفسي سبق إيداعه مرتين وتم الإفراج عنه مـع توافر خطورته وقام بإطلاق النار على الجمهور في أحد المحلات مسببا في قتل بعض الناس وإصابة آخرين("). غير أنه إذا لم يكن واضحا خطورة هذا المريض ولم يكن من المتوقع ما أقدم عليه من أفعال خطرة، فإن الخطأ كأساس لمسئولية الدولة بالتعويض لا}

(1) CE, sect, 13 juillet 1967, Département de la Moselle, rec. 341. Voir notamment : D. 1967 p. 675, note Moderne et RDSS 1968, p. 108, note Imbert

(2) CE, sect, 13 juillet 1967, Département de la Moselle, rec. 341. Voir notamment : D. 1967 p. 675, note Moderne et RDSS 1968, p. 108, note Imbert; CE, 17 nov. 1997, CHS Erstein, Dr. Adm. 1998, nº 128

$\left({ }^{3}\right)$ CE 11 juill. 1952, Cts Bruyère, CE 20 nov. 1964, Dame Soulaine, CE 13 juill. 1968, Min. Intérieur et Cne de Saulgé c/ Épx Hugonneau, CE 21 janv. 1991, $M^{\mathrm{me}}$ Berguerand et autres, préc, CE, ass., 23 janv. 1931, Dame et $D^{\text {lle }}$ Garcin, préc. supra, $n^{0} 584$

$\left.{ }^{4}\right)$ CE, sect., 31 déc. 1976, Hôpital psychiatrique de Saint-Égrève, préc. supra, $\mathrm{n}^{0}$ 583, CE 26 janv. 1979, préc. supra, $\mathrm{n}^{0}$ 584), Arrêt rendu par Conseil d'Etat, $5^{\text {ème }}$ et $3^{\text {ème }}$ sous-sections réunies, 26-01-1979, $n^{\circ}$ 99511, Recueil Lebon - Recueil des décisions du conseil d'Etat 1979 


$$
\begin{aligned}
& \text { يتوافر('). وبالمثل فإن إصدار المحافظ لقرار الإيداع في مستشفى غير ملائم كأسساس } \\
& \text { لمساعلة الدولة بالتعويض عن الأضرار التي تسبب فيها المريض النفسي('). } \\
& \text { ومن الواضح أن تطلب خطأ عاديا وليس جسيما لكي تنشأ مسئولية الدولة عن } \\
& \text { عمل مستثفى الأمراض النفسية يتجاهل صعوبة عمل تلك المستشفيات("). غير أنـه } \\
& \text { يؤخذ في الاعتبار حالة الاستعجال التي قد تبدو في بعض الظروف عند الأمر بإيداع } \\
& \text { المريض النفسي الذي يتسم سلوكه بـالخطورة() ). وقد قضي تطبيقـا لذلك بـأن تـأخر } \\
& \text { المحافظ في إصدار قرار بإيداع المريض العقلي بالمستشفى لمدة تزيد على ، ب يومـا } \\
& \text { ينطوي على خطا جسيم( ). كمـا أنـه قضي بـأن إصدار المحافظ قرار الإيـاع للمريض } \\
& \text { النفسي بدون استشارة طبيب نفسي يشكل خطأ جسيما إذا أدى إلى إيداع شخص دون } \\
& \text { توافر المرض النفسي المبرر لديـ("). و إذا تم إصدار قرار الإيداع بعد التثبت من أن }
\end{aligned}
$$

(1) CE 11 janv. 1985, $D^{\text {Ile }}$ Zurecki, CE 21 janv. 1991, $M^{\text {me }}$ Berguerand et autres, CE 14 avr. 1999, Sté Assurances générales de France c/ Cne d'Anctoville, CAA Nancy, 10 oct. 1996, Albrecht et autres, préc. supra, $n^{0} 584$

${ }^{2}$ ) CE 20 janv. 1989, Hôpitaux civils de Thiers c/ $M^{\mathrm{me}}$ Pinay, req. $\mathrm{n}^{\text {os }} 67978$ et 67979, Lebon T. 915

$\left(^{3}\right)$ Didier TRUCHET , Malades mentaux Civ. - Modes d'hospitalisation Répertoire de droit civil, Août 2006 (actualisatio)

$\left.{ }^{4}\right)$ CE, sect., 31 déc. 1976, Hôpital psychiatrique de Saint-Égrève, préc.

(5) CE 22 déc. 1982, Bissery, préc. supra, $\mathrm{n}^{0}$ 584), ou même, onze jours (CE 10 févr. 1984, $M^{\mathrm{me}}$ Dufour et 22 avr. 1988, Commissaire de la République du Cher $\mathrm{c} / \mathrm{M}^{\text {lle }}$ Rousseau, préc. supra, $\mathbf{n}^{0}$ 584)

$\left({ }^{6}\right)$ Paris, 14 avr. 1961, Agent judiciaire du Trésor public c/ G., préc.. Rappr. CA Toulouse, 23 janv. 1956, Préfet de la Haute-Garonne c/ X. et CA Paris, 13 avr. 1999, préc. 
المريض يشكل خطر ا على نفسه أو على الغير، فبان القرار لا يعتبر تعسفيا ولا يشكل

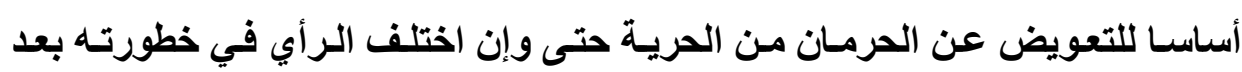

وتقوم مسئولية الدولة عند حبس المسجون المصاب باضطر اب عقلي بسبب

الأضرار التي تلحق زملاء له بالسجن. وقد قضي بمسئولية الدولـة بـالتعويض عن قتل المسجون المصاب باضطر اب عقلي لزميل له بالسجن استنادا إلى توافر الخطأ المرفقي

$$
\text { المتمثل في نقص الرقابة من جانب إدارة السجن('). }
$$

وفي حالة إيداع المريضة عقليا مركزا صحيا وكاتت معروفة بميولها الانتحارية

وهربت من هذا المركز الطبي وقامت بالاتتحار، فإن محكمة القضاء الإداري في فرنسا قضت بتوافر الخطأ في جانب المركز الطبي وأقرت بحق الأب رافع الدعوى بـالتعويض. وقد استتدت المحكمة في حكمها إلى توافر الخطأ الطبي في جاتب إدارة المركز الطبي

$$
\text { عندما قدرت عدم ضرورة إبلاغ الشرطة بهذا الفرار ("). }
$$

$\left.{ }^{1}\right)$ Civ. $2^{\mathrm{e}}, 19$ janv. 1962, $\mathrm{D}^{\text {lle }}$ Meslier e/ Préfet de police, Civ. $2^{\mathrm{e}}, 19$ janv. 1962, Épx Taillandier, Civ. $2^{\mathrm{e}}, 3$ mai 1963, Valette c/ Agent judiciaire du Trésor public, Civ. $2^{\mathrm{e}}, 28$ avr. 1965, Agent judiciaire du Trésor public $\mathrm{c} / \mathbf{V}^{\mathrm{ve}}$ Hadengue, Civ. $2^{\mathrm{e}}, 12$ mai 1975, Vernet c/ Préfet du Puyde-Dôme, préc.)

$\left(^{2}\right)$ Arrêt rendu par Tribunal administratif de Caen , 19-12-1967, Recueil Lebon - Recueil des décisions du conseil d'Etat 1967, Meurtre d'un prisonnier par un codétenu. Surveillance insuffisante. Malade mental connu comme dangereux. Responsabilité de l'Etat engage,

$\left(^{3}\right)$ Arrêt rendu par Cour administrative d'appel de Lyon, $1^{\text {ère }}$ chamber, 2603-1991, $\mathbf{n}^{\circ}$ 90LY00592, Recueil Lebon - Recueil des décisions du conseil d'Etat 1991 
وتسري قواعد المسئولية بدون الخطأ أي استتادا إلى تحمل المخاطر بالنسبة

للغير الذي تحمل ضررا من جراء الإفراج عن المريض العقلي الخطير قبل معالجته('). - إخلال إدارة المستثفى بالتزاماتها نحو المريض النفسي عند انتحاره: يقع على إدارة المستشفى التزام بالمحافظة على حيـاة المريض النفسي في المستشفى. وبنـاء عليه فِان القضاء الإداري قد قضى بتوافر الخطأ في جانب إدارة المستشفى التي تركت المريض نفسيا في صالة بالدور الثالث بمفرده وكانت الناقذة غير مؤمنة لكي تمنع أن يلقي بنفسه من أعلى وقام بإلقاء نفسه منها (†ال). وهنا تظهر صعوبة مهمة مستثفى الأمراض النفسية التي يجب أن تتخذ من التدابير ما يحول دون إيذاء المريض لنفسه أو لغيره، حتى وإن لم يظهر أن لايهه ميول

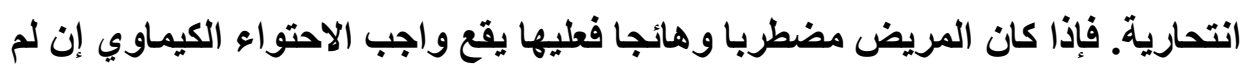

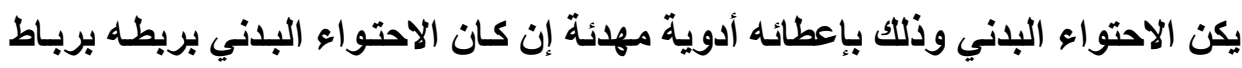

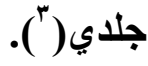

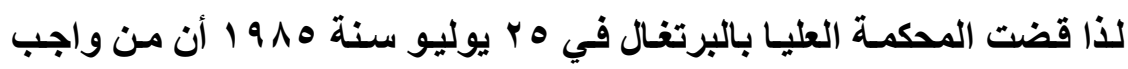
إدارة المستشفى أن تضمن مراقبة المريض نفسيا في داخل المستشفى وعدم خروجه إلا بتصريح وأن تتذذ ما يلزم من تدابير لضمان عودته إلى المستشفى عند اللزوم. غير إنيا

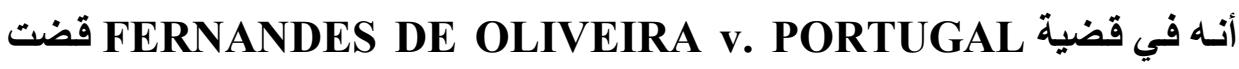
بأن النظام الذي كان يخضع لله المريض هو نظام الباب المفتوح وأن المريض غافل

(') Arrêt rendu par Tribunal administratif de Rennes, 07-12-1977, Recueil Lebon - Recueil des décisions du conseil d'Etat 1977

(') CAA Nancy, 2 août 2007, req. $\mathrm{n}^{\circ}$ 06NC00989, Mlle Y.

$\left.{ }^{3}\right)$ CAA Lyon, 22 juin 1999, req. $n^{\circ} 97 \mathrm{LY} 20753$ 
إدارة المستثفى وقفز من شباكك غرفته ثم بعد ذلك ألقى بنفسه أمام القطار. وبناء عليه

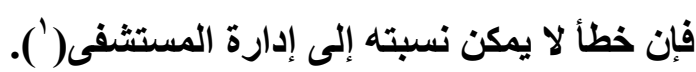

وقـ نعى أهل المـريض المنتحر على إدارة المستشفى أنهـا لـم تقـم بمراقبـة المريض الهارب بشكل صحيح ولم تقم بإقامة سياج لكي يمنع النزلاء من الهروب ولم تضع نظام للطوارئ لمتابعة حالات الهروب من المستثفى. وتقدر المحكمة الأوربية لحقوق الانسان بأنه يقع على الدولة التزام إيجابي أن

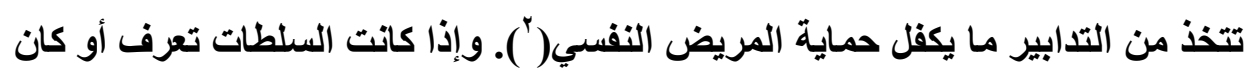
من الواجب عليها ان تعرف أن هناك خطرا حالا وجديا بأن المريض النفسي على وشك أن ينتحر، فإن عليها واجب أن تثتخل لمنعه محافظة عليه("). ولكي تقار المحكمة توافر هذا الخطر الحال والحقيقي تأخذ في اعتبارها العوامل

$$
\text { 1 - تاريخ المشكلات العقلية للمريض ("). }
$$

r - مدى خطورة المرض العقلي الذي يعاني منه المريض( ).

(1) CASE OF FERNANDES DE OLIVEIRA v. PORTUGAL, (Application no. 78103/14), 31 January 2019

(2) Haas v. Switzerland, no. 31322/07, § 54, ECHR 2011

(3) Keenan v. the United Kingdom, no. 27229/95, § 93, ECHR 2001-III)

(') see Volk v. Slovenia, no. 62120/09, § 86, 13 December 2012; Mitić, cited above; and Younger v. the United Kingdom (dec.), no. 57420/00, ECHR 2003-I

$\left(^{5}\right)$ see De Donder and De Clippel v. Belgium no. 8595/06, § 75, 6 December 2011 


$$
\text { ــ ــ ـ المحاولات السابقة للانتحار من جاتب المريض('). }
$$

Keenan v. the بتطبيق هذه المعايير على وقائع الدعوى - في قضية - United Kingdom الانتحار. وقد اخذت المحكمة في اعتبارها أن المريض كان يعالج في المستشفى تحت نظام العلاج الحر بدون حراسـة مشددة وفقا لمسا هو مقرر ومعروف من قواعد لهذا

وفيما يتعلق بوضع المريض في عزلة انتهت بانتحاره، فإن ذلك لا يعد خطأ من

جاتب المستشفى طالمـا أن حالته تبرر ذلك (مـادة L. 3211-3 CSP ). غير أنها إذا كانت المدة مبالغا فيها واجتمع معها إعطائه مهـئـات شديدة خوفا من مسلك مستقبل يمكن أن يصدر عنه، فإن ذلك يتحقق معه وجود خطأ في جانب الإدارة. وقد استتدت المحكمة في هذا الرأي إلى أن الدواء يجب أن يواجه حالة قائمة وليس تخوفا من حالة

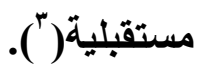
توفير الحماية الجنائية للمريض النفسي :

(') see Renolde, cited above, § 86; Ketreb v. France, no. 38447/09, § 78, 19 July 2012; and Çoşelav v. Turkey, no. 1413/07, § 57, 9 October 2012.

$\left(^{2}\right)$ CASE OF FERNANDES DE OLIVEIRA v. PORTUGAL, 31 January 2019, id

(3) CAA Nantes, 28 juin 2004, Centre hospitalier spécialisé de Pontorson, req. $\mathrm{n}^{\circ} 01 \mathrm{NT} 01862$ 
للوصـول إلـى هذه الأهداف، حرص القـانون المـصري فـي رعايـة المـريض

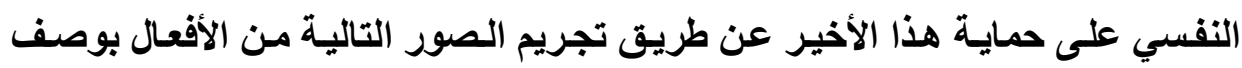

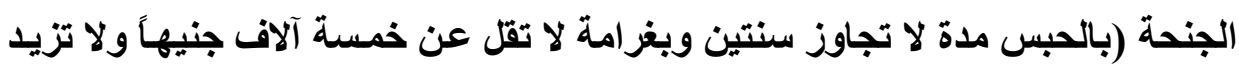
علي عشرة آلاف جنيهاً أو بإحدى هاتين العقوبتين": ـ الكذب في التقارير بخصوص حالة الثخص لإدخاله مستشفى الأمراض النفسية.

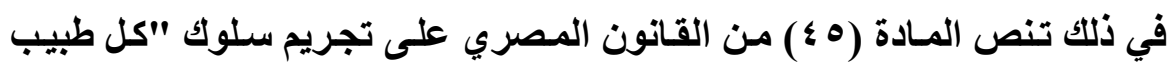

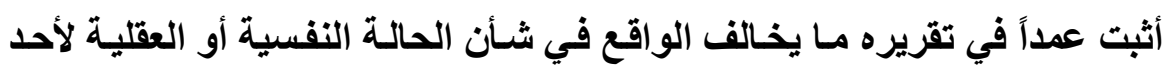

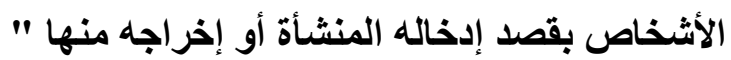

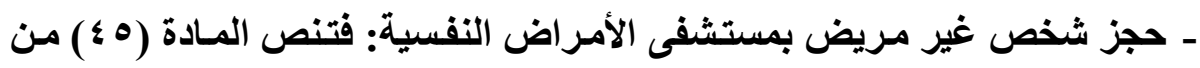

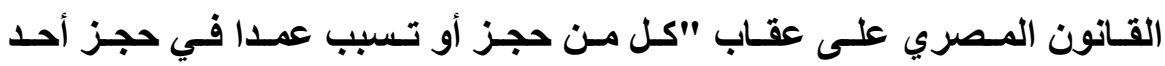

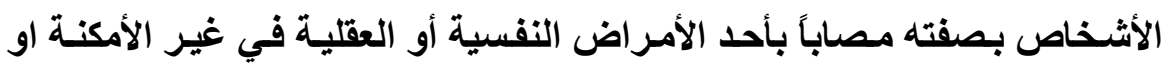
الأحوال المنصوص عليها في هذا القانون".

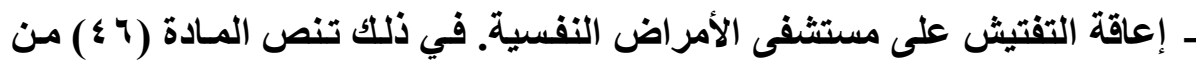

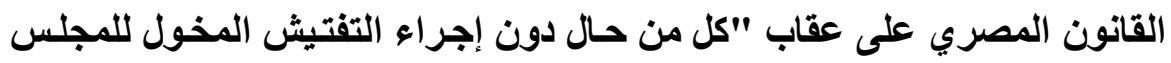

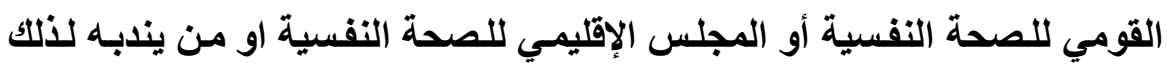

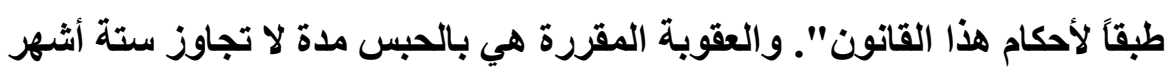
وبغرامة لا تزيد على ثلاثة آلاف جنيها أو بإحدى هاتين العقوبتين.

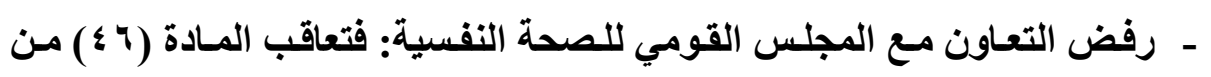
القانون المصري بالعقوبة السابقة "كل من رفض إعطاء معلومسات يحتاج إليها

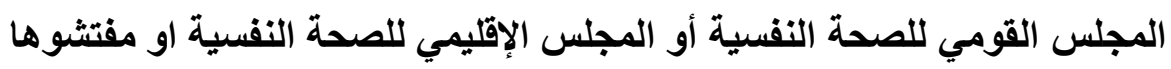

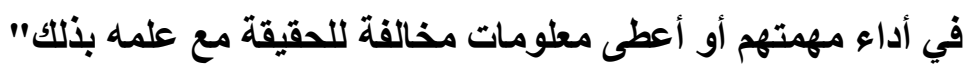


ـ الإبلاغ كذبا عن مريض نفسي: فتعاقب المادة (؟ ع ) "كل من أبلـغ إحدى الجهات المختصة كذباً مع سوء القصد في حق أحد الأشخاص بأنـه مصاب بمرض نفسي مما نصت عليه أحكام هذا القانون".

ويعاقب القانون المصري على إساءة معاملة المريض النفسي بـالحبس مدة لا تجـاوز سـنة وبغرامـة لا تزيــ على خمسة آلاف جنيهاً أو بإحدى هـاتين العقوبتين في المـادة (V \& ) " كل من كان مكلفاً بحراسـة أو تمريض أو علاج شخص مصاب بمرض نفسي وأساء معاملته أو أهمله بطريقة مـن شـأنها أن تحدث لـه آلامـا أو أضراراً. و إذا تزتب على سـوء المعاملـة مـرض أو إصـابة أو إعاقة بجسم المـريض تكون العقوبـة الحبس مدة لا تجاوز ثلاث سنوات"

وفي نفس الاتجاه يعاقب القانون القطري على توفير عقاب من يعامل المريض نفسيا معاملة غير إنسانية بقوله في المادة (Y^) منه على أنه " مـع عدم الإخلال بـأي عقوبة أثد ينص عليها قانون آخر، يعاقب بالحبس مدة لا تجاوز سنة وبالغرامة التي لا

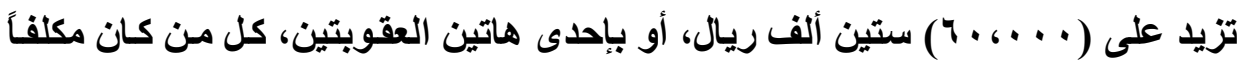
بحراسـة أو تمـريض أو علاج شــص مـصاب بمـرض نفسي وأسـاء معاملته أو أملـه بطريقة من شأنها أن تُحدث له آلامَاً أو أضراراً

وتكون العقوبة الحبس مدة لا تجاوز ثلاث سنوات إذا ترتب على سوء المعاملة أو الإهمال مرض أو إصابة أو إعاقة بجسم المريض". ويـأتي هذا بعد أن قرر العقـاب على من يحجز شخصا في مستشفى للأمر اض النفسية بدون وجهه حق أو يتسبب في هذا الحجز غير القـانوني وكذلك مـن يفشي أسرار المريض نفسيا (المـادة ج ج مـن القانون القطري) وبالمثل فإن القانون المصري يعاقب كل من يخالف واجب السرية إزاء المـريض النفسي (مـادة 9 ؛). وعلى الـرغم مـن عدم نـص القـانون المصري أو 
القانون القطري على الملتزمين بالسرية فإنه من المنطقي أن ينحصر هذا الالتزام على

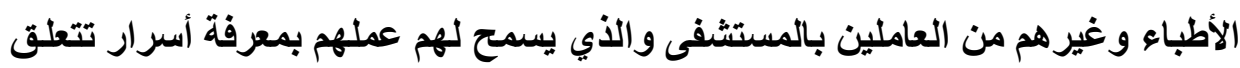

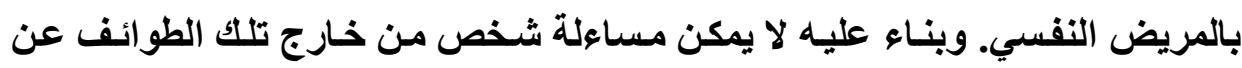
إفثشاء ما علمه من أسرار هذا المريض.

و إمعانا في حماية المريض نفسيا قرر القانون القطري مسئولية القائم بإدارة

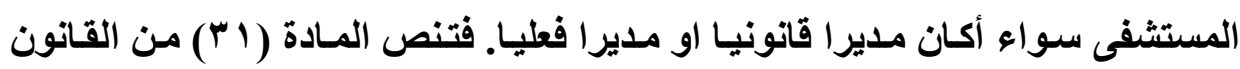

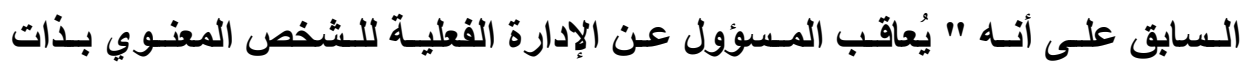
العقوبات المقررة عن الأفعال التي ترتكب بالمخالفة لأحكام هذا القانون، إذا ثبت علمده الفاله

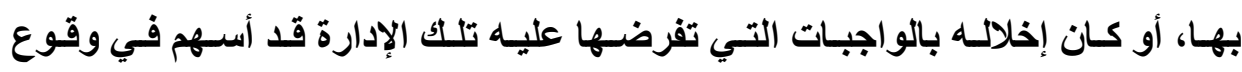

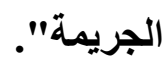

وهنا فإنها يعاب على النص السابق ما يلي: ـ أنه قرر المسئولية الجنائية للمدير الفعلي دون أن يتعرض للمدير القانوني. وهذا لا

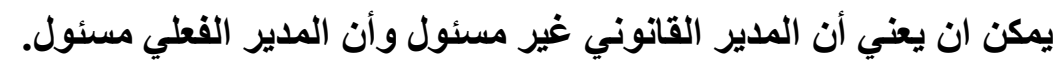
- إن المسئولية الجنائية تقوم عن فعل أحد العاملين تحت إدارتهه عن أي من الجرائم

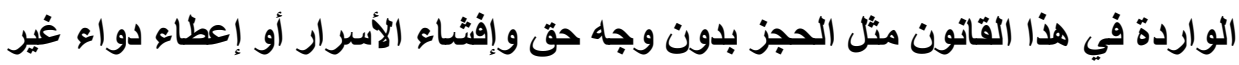

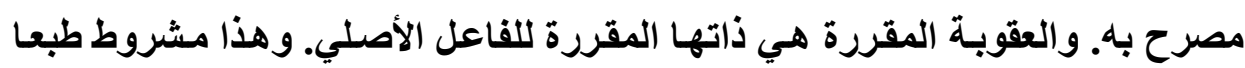
بطله بالأفعال التي يرتكبها غيره من تحت رئاسته (مادة الم). 


\section{المبحث الثاني \\ مدى تمتع المريض النفسي بمقوق الانسان المريض}

أصبح المريض نفسيا صـاحبا للحقوق الأساسية التـي يتمتع بها غيره من

المرضى وقد قررت المواثيق الدولية والقوانين المقارنة هذا الحق (مطلب أول) حق القي

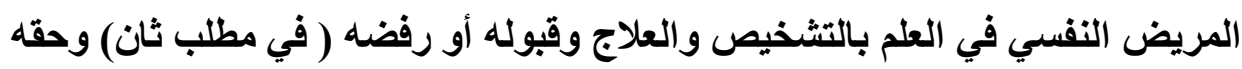

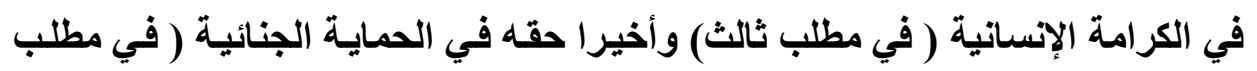
رابع).

\section{المطاب الأول}

تقرير حقوق المريض نفسيا على المستوى الإقليسي والدولي

ـ مجموعة الحقوق التي قررتها الأمم المتحدة للمرضى النفسيين في 999 19:

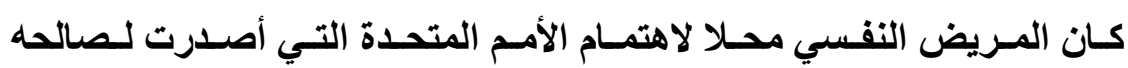
مجموعة من الصكوك التي تحمي حقوقه بعنوان "مبادئ حماية الأثخاص المصابين

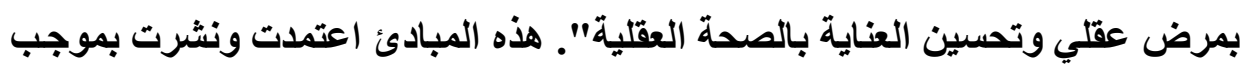

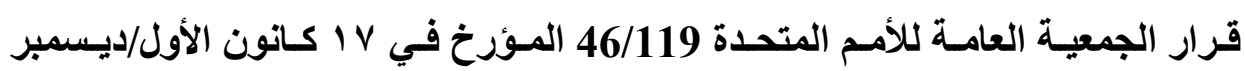

من أهم الحقوق والحريات الأساسية للمريض النفسي التي أكدت عليها الأمم المتحدة

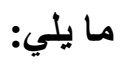
ـالحق في الرعاية العقلية كجزء من الرعاية الصحية والاجتماعية: 
ـ الحق في المعاملة التي تكفل الكرامـة الإنسانية للمريض النفسي؛ فلا يجوز تقييد

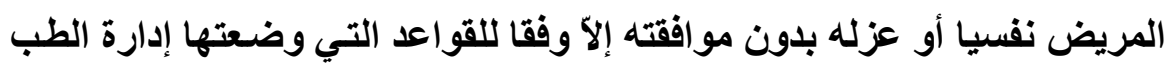

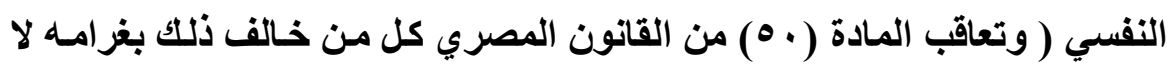
تقل عن ثلاثة ألاف جنيه ولاتئ (تزيد عن عثرة ألاف جنيه). ـ الحق في علاج مناسب لا يشكل تعذيبا أو إيذاء أو معاملة قاسية أو غير إنسانية أو حاطة بالكرامة. ـ حمايسة المريض النفسي مـن اسـتخدام العلاج في مواجهتهـه بغرض التعـيب أو لتحقيق راحة الأخرين. ـ الحق في رفض العلاج في حالة عدم الموافقة عليه ، وعند الموافقة يجب أن يكون الرضاء مستتيرا ، باستثناء حالات الاخول غير الإرادي وحالة الضرورة. ـ لا يجوز مطلقا إجراء التعقيم كعلاج للمرض العقلي. ـ لا يجـوز مطلقـا إجراء تجـارب إكلينيكية وعـلاج تجريبـي على أي مـريض دون

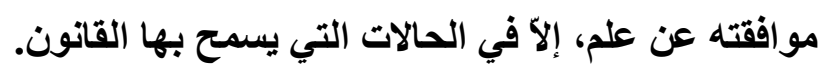
ـ الحق في الحماية من الاستغلال البدني أو الاقتصادي أو الجنسي. ـ الحماية من التمييز ضد المريض النفسي في المعاملة ـ الحق في التمتع بـالحقوق المدنية والسياسية والاقتصادية المقررة في العهود

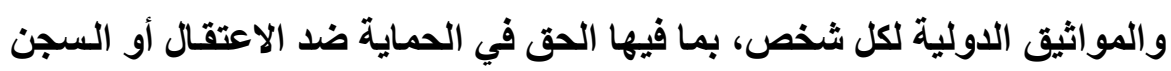
غير القانوني. ـ الحق في دعوى عادلة بما فيها الحقى في الدفاع عند تعيين من يمثله قانونا لتحقيق مصالح المريض نفسيا. 
ـ الحق في الطعن في أي قرار يمس مصلحة المريض نفسيا أمام القضاء. ـ الحق في الالتجاء إلى القضاء لتعيين من هو أصلح للحفاظ على مصالح المريض النفسي. - لا يجوز في أي ظرف إخضاع مريض للعمل الإجباري. ـ الحق في بيئة مناسبة للمريض النفسي ويشمل ذلك أنشطة ترويحية وتعليمية وعمل يختاره المريض ويناسب حالته.

ـحقوق المعاقين ذهنيا في اتفاقية الأمم المتحدة لحماية المعاقين:

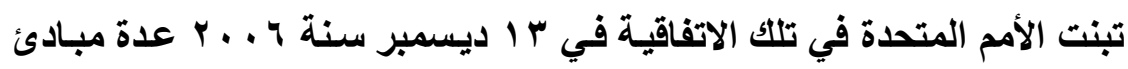
في شأن المعاقين والذين يشملون المعاقين ذهنيا وفقا للمـادة الأولى من الاتفاقية. من أهم تلك المبادئ ما يلي: - ضرورة احترام الكرامة الإنسانية - - أهمية تحقيق اندماج المعاق في المجتمع - مبدأ عدم التمييز - مبيز

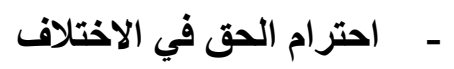

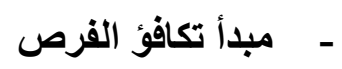

- - الحق في الحرية الفردية والأمن - الحق في الحمايـة مـن التعذيب والمعاملـة غير الإنسانية أو الحاطة بالكرامـة الانساتية - الحماية من الاستغلال بجميع صوره وأشكاله - الحق في السلامة الجسدية - الحق في التعبير والحصول على المعلومات 


$$
\begin{aligned}
& \text { - الحق في الخصوصية } \\
& \text { - الحق في التعليم } \\
& \text { - الحق في الصحة } \\
& \text { - الحق في إعادة التأهيل } \\
& \text { - الحق في المشاركة السياسية } \\
& \text { - الحق في مستوى لائق من الحياة } \\
& \text { - الحق في العمل } \\
& \text { - الحق في الثقافة والترويح }
\end{aligned}
$$

كل ذلك يؤكد أن المريض نفسيا من حقه أن يتمتع بحقوق الانسان التي يتمتع

$$
\text { بها الشخص غير المريض. }
$$

ـ إقرار القانون المصري لحقوق المريض النفسي:

صدر في مصر القانون رقم V V لسنة و . . ب بشأن رعايـة المريض التفسي

لكي يشتمل على أحكام تنظم حالات دخول المريض النفسي إلى مستشفى الأمراض النفسية وطريقة معالجتهـ داخل تلك المنشأة وخارجها. يضاف إلى ذلك مسا تضمنه القانون من مسئوليات تقع على عاتق أطباء الطب النفسي وإدارة المستشفى وحالات خروج المريض النفسي عند انتهاء علاجه وكذلك عند تعديل الرعايـة الطبيـة بحيث تعطى في الوسط الحر. وقد حرص القانون المصري على التأكيد على حقوق المريض النفسي وزيادة الضمانات المقررة له على غرار المريض العادي. كما أصدرت التشريعات العربية قوانين خاصة بحماية المريض النفسي. من تلك الدول دولة قطر التي أصدرت القانون رقم (צ 1 ) لسنة 7 ـ ـ بشأن الصحة النفسية لكي ينظم الدخول والخروج إلى مستشفى الطب النفسي ويعدد الضمانات والحقوق المقررة للمريض النفسي. 
وتقرر المادة L. 3211-2-2 من القانون الفرنسي المعدل بالقانون رقم ب ـ A

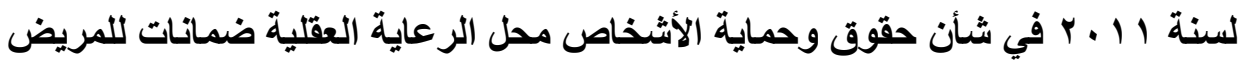

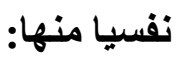

- وجوب فحصه وإعاد شهادة طبية بالتثخيص والحاجة إلى الإيداع في خلال ؛ ب ساعة من وقت صدور القرار بالإيداع - لا يجوز لهذا الطيبب أن يصدر شهادة أو اثثين التي على أساسها تم إصدار قرار الإيداع قبلا ذلك. - ان يصدر طبيب نفسي بالمستشفى شهادة أخرى قبل مضي ل لخول المريض تثبت التثخيص وبرنامج العلاج

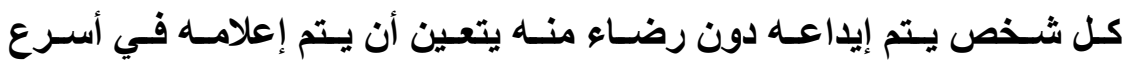
وقت ممكن بتشخيص حالته ويقرار إيداعه وبكل قرار اتخذ في شـأنه مع بيان أسباب ذنك.

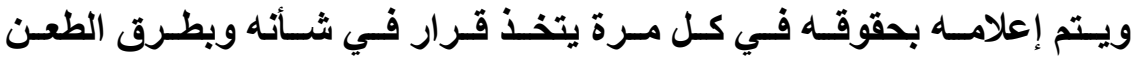

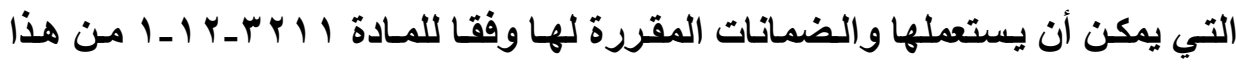

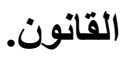




\section{الاطلب الثاني \\ حق المريض النفسي في العلم بالتشخيص والعلاج \\ وقبول العلاج أو رنضه \\ ـ الحق في الاطلاع على الملف الطبي:}

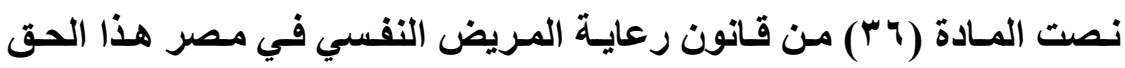

بقولها " 1 ـ ـالحصول على تقرير طبى كامل عن حالته النفسية وعن كافة الفحوصـات

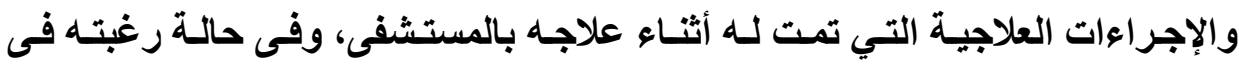
الحصول على صوره ضوئية من الملف كـاملا أن يلجأ إلى المجلس المختص للصحة النفسية ويجوز للمجلس حجب هذا الحق مؤقتا لأسباب علاجيه ويحق للمريض التظلم

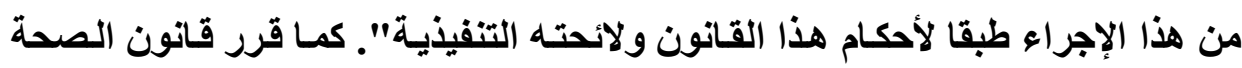

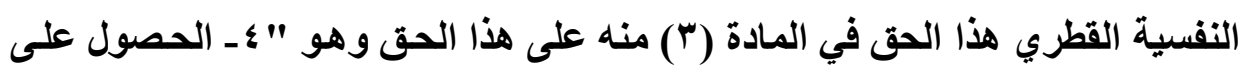
تقرير طبي كامل عن حالته النفسية، وعن جميع الفحوصات والإجراءات العلاجية التي تمت له أثناء علاجه بالمؤسسة، وللمؤسسة حجب هذا الحق مؤقتاً لأسباب علاجية" كمــــرر القضاء الفرنسـي حق المـريض (عن طريـق ممثلـهـ القـانوني) في الاطلاع على ملفهـ الطبي. ويفسر هذا القضاء المقصود بـالملف الطبي بحيث يشمل جميع الأوراق التي يكتبها الطبيب والتي ساعدت على تشخيص الحالة وإعداد برنـامج العلاج('). وقد قضي لصالح المريض بالتعويض بسبب أن الإدارة لم تمكنه من الاطلاع

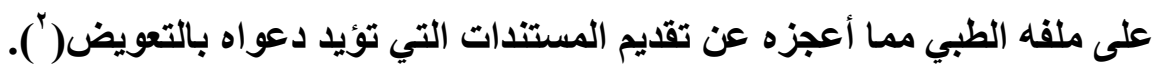

(1) CE, 28 avril 2003, $n^{\circ}$ 238181, M. André $X$

$\left(^{2}\right)$ TA Marseille, 10 avril 2007, $n^{\circ} 0503487$, M. A. E. 
وقد أكدت المادة 11 في الاطلاع على ملفه الطبي سواء مباثرة أو عن طريق طبيب منتدب من جانبه. وقد

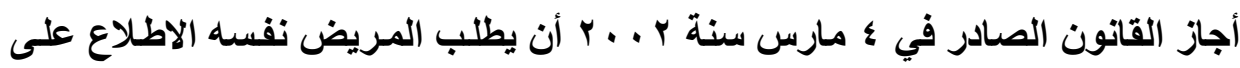

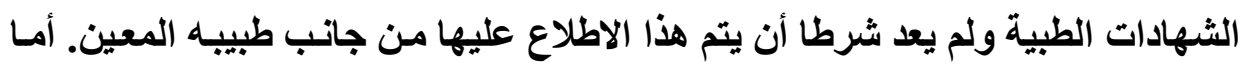
ما يتعلق بغيرها من محتويات الملف الطبي، فإنه يلزم أن يتم ذلك من جاتب طبيب حتى منى لا يترتب عليهه أضرار على المريض النفسي بسبب الاطلاع على التشخيص ونسبة هلية الشفاء...('). كمسا أن مـن حق المريض أن يطلع على القرارات الصادرة بخصوص إيداعه وتجديد ذلك الإيداع. في ذلك قضي بأن مسلك الإدارة في تأخير اطلاع المريض ومن يمثله على محتوى مذكرة أعدتها إخصائية الشئون الاجتماعية بخصوص إيداعه

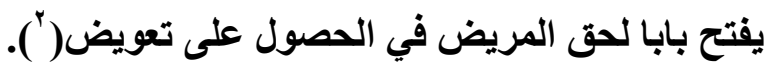
وقد اتجه القضاء الإداري الفرنسي إلى أن المحافظ الذي أمر بالإيداع للمريض

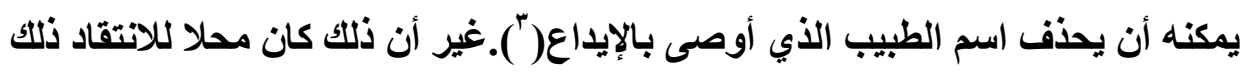
أن هذا من شأنه أن يحرم المريض من الطعن في القرار من ناحية استناده إلى شهـادة طبيب لا يجيز القانون له ذلك بسبب استبعاده من جانب القانون( )ع. وفي كل الأحوال يلتزم مدير المستشفى وإدارتها بالحفـاظ على أسرار المريض وبياناتـه الشخصية. ومـن ثم فإنـه لا يسأل إن هو رفض اطلاع مـن ليس مخـولا لـه

(1) CAA Nantes, 3ème ch., 7 oct. 1999, req. n 96NT01287, D. 2001, II,p. 275

$\left(^{2}\right)$ CE, 19 oct. 2007, $n^{\circ}$ 296529, M. François A.

$\left(^{3}\right)$ CAA Nantes, 3ème ch., 7 oct. 1999, req. n 96NT01287, D. 2001, II,p. 275

$\left.{ }^{4}\right)$ Sandra MONOD, Le juge administratif et l'hospitalisation sans consentement, Master II (recherche) de droit public, 4 juillet 2008, Faculté de droit et de science politique,Université de Rennes, P. 67 
الاطلاع على تلك البيانـات('). وينتمسي إلى تلك البيانـات الطلب الذي تقدم بـه شخص معين لكي يتم إيداع المريض. هذا الطلب لا يجوز إفشاؤه إلى المريض أو من يمثله( ()). -حق المريض في العلم بحالته الصحية: قرر القانون المصري الحق في العلم بطبيعة العلاج بنصه في المسادة ( rV ) على أن "فـي حالـة تمتـع المـريض بالقـدرة العقليـة علـى فهـم وإدراك الإجـراءات والمعلومـات المقدمسة إليـه واتخـاذ قرار مبنى على هذا الإدراك والتعبير عنـه تعبيرا صحيحا يلتزم الطبيب النفسي المسئول بعدم اعطاء أي علاج لمريض الدخول الارادي دون الحصول على موافقته المسبقة المبنيـة على إرادة حرة مستنيرة ،كمـا يلتزم بتسجيل الخطة العلاجية المقترحة، واثبات موافقة المريض أو عدم موافقته في الملف الف الفوله الطبي لله وذلك طبقاً للثروط والإجراءات التي تحددها اللائحة التنفيذية لهذا القانون . وتقع مسئولية تقرير قرة المريض العقلية على إعطاء موافقه صريحه ومستنيره من عدمه على الطبيب النفسي المسئول. وفى جميع الأحوال يلتزم أعضاء الفريق العلاجي بتسجيل كل تلخل علاجي يقوم به أي منهم بملف المريض وذلك على النحو الذي تبينه

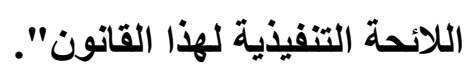

وتـضمن القـانون القطري مجموعـة مـن الحقـوق التـي يجب أن يتمتـع بهـا المريض نفسيا. من أهمها حقه في العلم بالعلاج. فتنص المادة (ّ) منه على أن "تلتزم المؤسسات المنصوص عليها في المـادة السابقة، بأن توفر للمريض النفسي الحقوق التالية

(1) CAA Nantes, 3ème ch., 7 oct. 1999, req. n 96NT01287, D. 2001, II,p. 275,

(') CADA, avis du 19 octobre $2000, n^{\circ} 20003907$. 
ا ـ تلقي شرح وافٍِ بأسلوب يفهمه، لجميع الحقوق الواردة بالقانون عقب الدخول

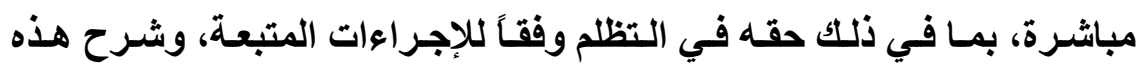
الحقوق لأقاربه أو ولي أمره في حالة عجزه عن فهمها r ـ إعلامـه أو ولي أمره بالتشخيص، وبالخدمات العلاجية المتوفرة في المؤسسة وكيفية الحصول عليها، وحالات منعه منها، وبالخطة العلاجية قبل البدء فيها،

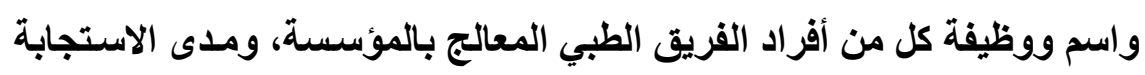
المتوقعة لها، والفوائد المرجوة منها، والمخاطر والأعراض الجانبية المحتملة، والبائل العلاجية المكنة، وأي تغيير يطرأ على حالته، وأسباب إحالته إلى أي قسم أو مكان آخر داخل المؤسسة أو خارجها، منى كاتت هناك حاجة لذلكل". ققد قرر المشرع القطري حق المريض نفسيا في العلم بنوع العلاج النفسي الذي يتعاطاه. وفي حالة عدم أهليته، من حق ولي الأمر أن يطلع على نوع العلاج

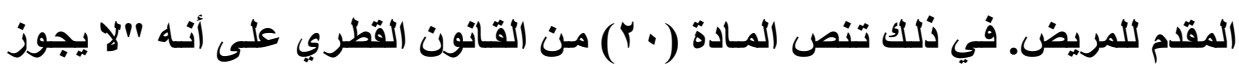
إعطاء المريض النفسي أي عـلاج لحالته، سـواء كـان هذا العلاج دوائياً أو نفسياً أو

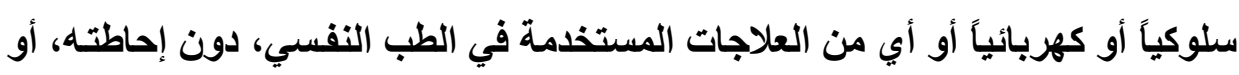
ولي أمره إذا كان ناقص الأهلية، علماً بذلك ". وبهـذا فـانْ المسشرع القطري يقيم التمانـل الـضروري بـين المـريض نفسيا والمريض العادي؛ فكلاهما يلزم أن يعلم بطبيعة العلاج الأي يخضع له. غير أنه يلاحظ أن القانون المصري لم ينص على الحق في العلم بطبيعة العلاج إلا للمريض نفسيا دون ولي الأمر إذا كان يتمتع بالقدرة على الفهم والاستيعاب. وكان من الأفضل أن ياخل ولي الأمر في العلم بالعلاج. غير أن القانون المصري يتميز بأنـه 
تحدث عن الرضاء المستتير. ويقصد به العلم بالعلاج وكذلك العلم بالإثار الجانبية التي يمكن أن تترتب عليه (مادة Y^).

ومع ذلك فإن موقف المشرع القطري لا يزال يقف في موقف أقل من الكلازم في خصوص التزام الطبيب النفسي بتبـير المـريض بطبيعـة العـلاج وبآثـاره الجاتبيـة وتبعاته. وقد كان من اللازم النص على ضرورة توافر الرضساء المستتير وخاصسة في حالة الإدخال الإرادي. وبخصوص الاخول الإلزامي فإن المشرع لم ينص على ذلك وقد كان من المناسب أن يتم إخطار ولي الأمر بطبيعة العلاج وآثاره الجانبية، مـع استثناء حالة الضرورة.

ـ الحق في الرضاء بالعلاج وحدود هذا الحق: ـ الأصل هو ضرورة الرضاء بالعلاج: بعد أن يعلم المريض بملفه الطبي وبعد أن يعلم بتشخيص حالته، من الواجب

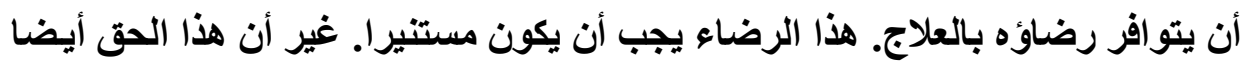
ترد عليه بعض القيود.

فمن حق المريض نفسيا أن يعلم بمـا يُعطى من علاج وآثـاره الجانبية، وذلك

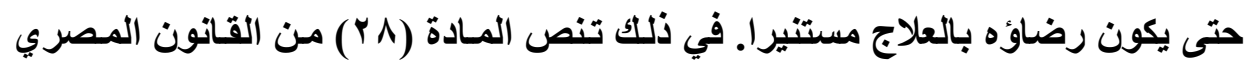
في شأن رعاية المريض النفسي على أنه "لا يجوز إعطاء المريض النفسي أي علاج لحالته سواء كان هذا العلاج دوائيا أو نفسيا أو سلوكيا أو كهربائيا أو أي من العلاجـات المستخدم في الطب النفسي دون إحاطته علما بذلك ، ويتعين إحاطته علمـا بطبيعة هذا العلاج والغرض منه والآثار التي قد تنجم عنه والبدائل العلاجية له ..." وبناء عليه فإن الرضساء المستنير لا يكون من جانب المريض النفسي إلاً إذا تضمن إعلامه بالنتائج المحتمل ترتبها على العلاج وليس فقط بسير العلاج المقترح. 
وبالطبع إذا لم يكن المريض قادرا على الفهم وهذا هو الغالب، فإن القيم عنه هو الذي

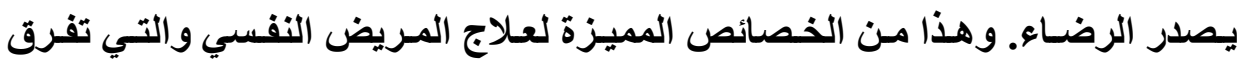
المريض نفسيا عن المريض جسميا. ـ القيد الوارد على الرضاء: جواز الإجبار مما يميز المريض نفسيا عن المريض جسميا أنه يجوز إجباره على نوع معين

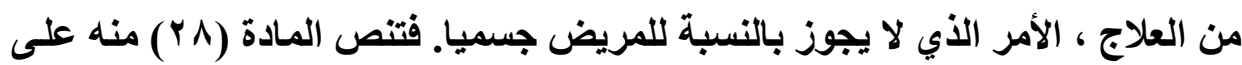

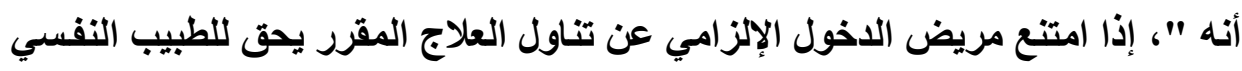
المسئول إلزامسه بـالعلاج ، على أن يستوفى الطبيب إجراءات العـلاج الإلزامسي قبـل

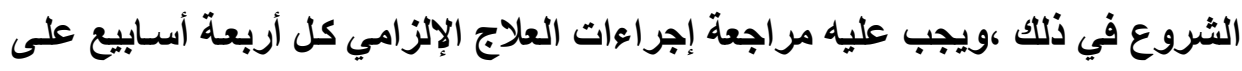

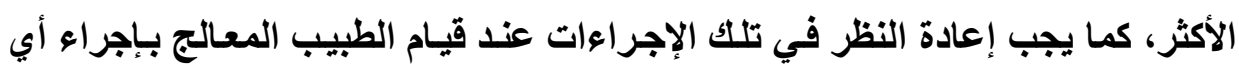

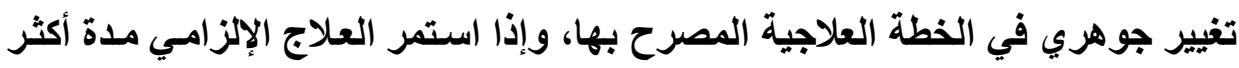

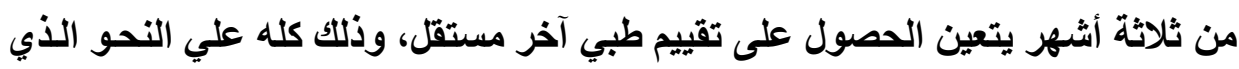
تبينه اللائحة التنفيذية لهذا القانون".

وبالمثل قرر القانون القطري حق المريض نفسيا في رفض العلاج في حالة

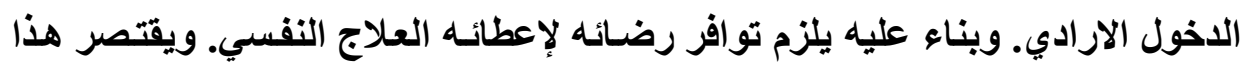

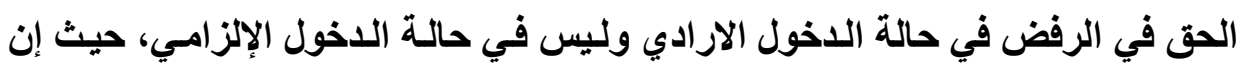

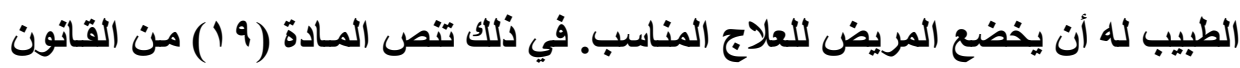

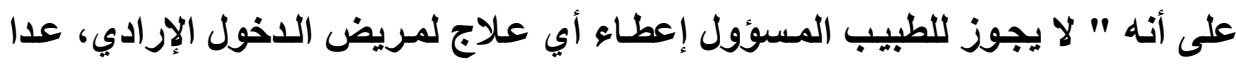

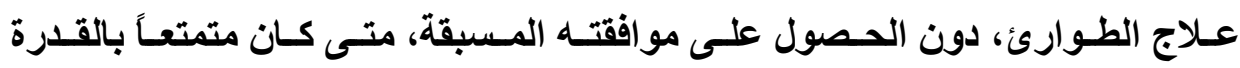

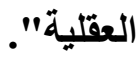


وتتجه التثريعات المقارنة إلى نفس الاتجاه فيمـا يخص اللدخول الإرادي حيث تنص المادة (YV) على أنه "في حالة تمتع المريض بالقدرة العقلية على فهم وإدراك الإجراءات والمعلومات المقدمة إليه واتخاذ قرار مبني على هذا الإدراك والتعبير عنـه تعبيراً صحيحا، يلتزم الطبيب النفسي المسئول بعدم إعطاء أي علاج لمريض الدخول الإرادي دون الحصول على موافقته المسبقة المبنية على إرادة حرة مستنيرة كما يلتزم بتسجيل الخطة العلاجية المقترحة وإثبات موافقة المريض أو عدم موافقته في الملف

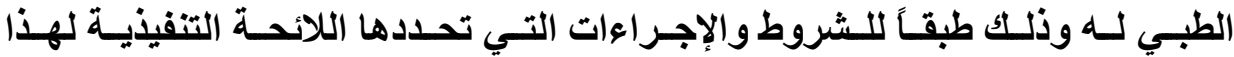

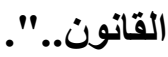

وقد أكدت المادة (· †) من القاتون القطري على جواز إجبار المريض النفسي على الخضوع للعلاج في حالة اللاخول الإلزامي بقولها "وإذا امتتع مريض اللدخول الإلزامي عن تناول العلاج المقرر، يحق للطبيب المسؤول إلزامـه بـالعلاج، ويجب عليه مراجعة إجراءات العلاج مرة كل ثلاثين يوماً على الأكثر، كما يجب إعادة النظر في تلك التك الإجراءات عند قيام الطبيب المسؤول بـإجراء أي تغيير جوهري في الخطة العلاجية

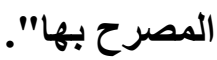
وقد تطلبت المادة (9 1 ) من الطبيب المعالج أن يتأكد من توافر رضاء المريض في حالة الاخول الإرادي ويقع عليه عبء إثبات أن رضاءه بالعلاج كان كاملا. ومع ذلك فقد أفسحت المادة السابقة مجالا لحالة الضرورة التي تجيز للطبيب النفسي إعطاء علاج للمريض نفسيا بقولها "واستثناءً من حكم الفقرة الأولى من هذه المادة، يجوز في حالة الضرورة العاجلة إعطاء المريض النفسي العلاج دون الحصول على موافقته، متـى كـان ذلـك لازمـاً لمنـع حدوث تـــهور وشـيك للحالـة النفسية أو 
الجسمانية للمـريض، أو دفـع خطر جسيم يهـدد حياتـهـه أو صـته أو حيـاة أو صـحة الآخرين، على ألا تجاوز مدته اثنتين وسبعين ساعة

وفي جميع الأحوال، يلتزم الطبيب المسؤول بتسجيل كل تـخل علاجي يقوم بـه

$$
\text { بملف المريض". }
$$

فـالمعول عليهه هو تحقيق مصلحة المريض النفسي ولذا يجوز إجباره على في العلاج الأي رفضه مادام ذلك كان ضروريا لمصلحته. فتنص المسادة (9 ץ) من القانون المصري على أنه "يجوز في حالـة الضرورة العاجلة إعطاء المريض النفسي العلاج دون الحصول على موافقته متى كـان ذلك لازمـا لمنـع حدوث تـدهور وشيك للحالة النفسية أو الجسدية للمريض من شـانها أن تعرض حياته أو صحته أو حيـاة وصحة الآخرين لخطر جسيم وشيك على ألا تتجاوز مدته إثنين وسبعين سـاعة وذلك طبقا لمسا تحدده اللائحة التنفيذية لهذا القانون". ـالوضع الخاص بالرضاء بالعلاج الكهربائي: أفرد القانون المصري وضع خاصا للعلاج الكهربائي حيث تطلب بعض الثروط منها شرط التخدير وإعطاء باسط للعضلات والرضساء المستنير والعلم بطبيعة العلاج والآثار الجاتبية والبدائل العلاجية لـه. في ذلك تنص المـادة (• ب) منـه على انهـ ": لا يجوز إجراء العلاج الكهربائي اللازم لحالة المريض النفسي إلا تحت تـأثير مخدر عـام وباسط للعضلات، ويتعين الحصول على موافقته على ذلك كتابـة بنـاء على إرادة حره مستنيره وبعد إحاطته علما بطبيعة هذا العلاج والغرض منه ، والأثار الجانبية التي قد

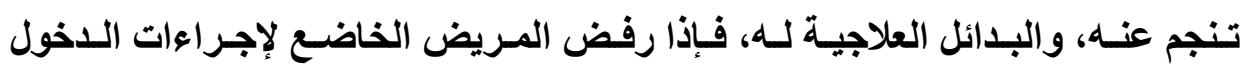
والعلاج الإلزامي هذا النوع من العلاج وكان لازما لحالته فرض عليه بعد إجراء تقيبم

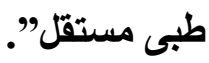


كمسا اتجـه القـانون القطري نفس الاتجـاه بخصوص العـلاج الكهربـائي حيث اشترط موافقة المريض عليه. فقد نصت المادة (Y l) من القانون القطري على أنه " لا يجوز إجراء العلاج الكهربائي اللازم لحالة المريض النفسي إلا تحت تـأثير مخدر عـام وباسط للعضلات، ويتعين الحصول على موافقة كتابية من المريض أو ولهي أمره إذا كان ناقص الأهلية، بعد إحاطته علماً بطبيعة هذا العلاج والغرض منه، والآثار الجانبية التي قد تتجم عنه والبدائل العلاجية له ...".

غير أن المادة السابقة استثثت عند العلاج الكهربائي توافر حالة الضرورة عند اللـخول الإلزامسي بقولها " فـإذا رفض المريض التفسي الخاضـع لإجـراءات الــخول الإلزامي أو ولي أمره هذا النوع من العلاج، وكـان لازمساً لحالـة المريض، ألزم بـه بعد إجراء تقييم طبي مستقل"

والنص على جواز استعمال العلاج الكهربائي المتمثل في صدمات كهربائية هو

محل انتقاد بسبب عدم توافر الضمانات اللازمة للقيام بهذا العمل. فيجب ان تتم مراجعة هذا النـوع من العـلاج قبل تنفيذه مـن جانب استشاري طب عقلي من غير العـاملين بالمستشفى ومن غير أقارب الطبيب الذي أوصى بـه بالمستشفى كمـا يجب استشارة طبيب التخدير وطبيب أمر اض القلب والباطنية نظرا لآثاره الخطيرة. وهذا بصفة خاصة باتة

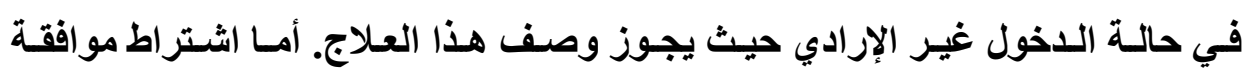
المريض أو ولي أمره، فإنه يحدث كثيرا أن لا يدرك المريض خطورة هذا العلاج كمـا أن ولي الأمر لا يفهم أمور العلاج اللازم للمريض نفسيا. 


\section{المطلب الثالث}

حق المريض النفسي في الكراهة الإنسانية

عند التعاهل همه

- حق المريض النفسي في الكرامة الإنسانية:

احترام الكرامة الإنسانية من المبادئ الدستورية المقررة لصالح الفرد العادي

أو المريض الجسمي أو المريض النفسي. وقد جرت أحكام المجلس الاستوري الفرنسي هن العيدي

$$
\text { على ذلكك('). (1). }
$$

وقد نصت الاتفاقية الأوربية لحقوق الانسان على حق الفرد في الحرية الفردية

فلا يحجز بمستشفى الأمراض النفسية إلا إذا كان مصابا بمرض عقلمي وفقا للقانون.

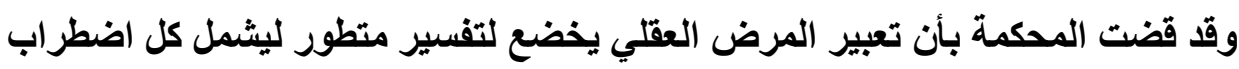

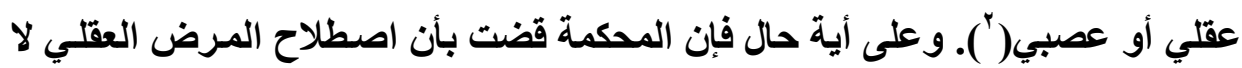
يجب أن يمتد لكي يشمل كل من يبدو سلوكه غريبا بالنسبة للمجتمع الذي يحيط بهان آ).

(') C. civ., art. 16 . - V. Cons. const. 27 juill. 1994, $n^{0}$ 93-343/344 DC, D. 1995. 237, note Mathieu ; D. 1995. Somm. 299, obs. Favoreu .V. aussi Cons. const. 16 juill. 1996, $\mathrm{n}^{0}$ 96-377 DC, D. 1997. 69, note Mercuzot ; D. 1998. Somm. 147, obs. Renoux ; JCP 1996. II. 22709, note Nguyen Van Tuong ; LPA 20 nov. 1996, p. 5, note Mathieu),

(') CEDH 24 oct. 1979, req. $n^{0}$ 6301/73, Winterwerp c/ Pays-Bas, Série A, $n^{0} 33$, p. 16, § 37

$\left(^{3}\right)$ CEDH 24 oct. 1979, op.cit; CEDH 30 juill. 1998, req. $n^{0}$ 61/1997/845/1051, Aerts c/ Belgique, § 46. - CEDH 28 mai 1985, req. $n^{0} 8225 / 78$, Ashingdane c/ Royaume-Uni, Série A, no 93, § 44. - V. aussi CEDH, $3^{\mathrm{e}}$ sect., 5 avr. 2011, Nelissen c/ Pays-Bas, Dalloz actualité, $=$ 
وقد تعرض أحكام القضاء الفرنسي لحق المريض في الكرامـة الإنسانية من

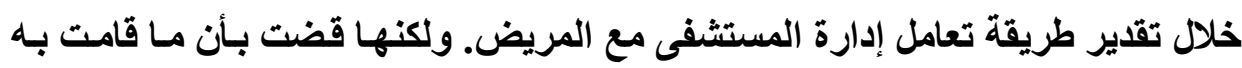

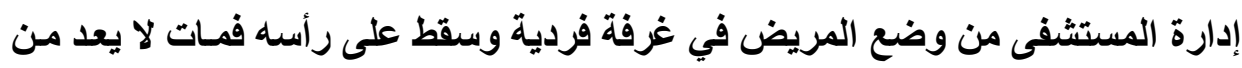

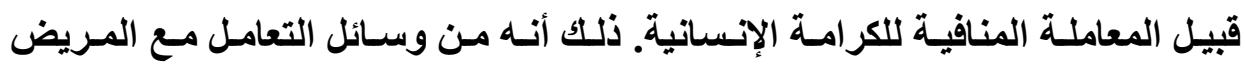
النفسي جواز وضعه في غرفة منفردة. كما قضي أن عدم وضع قيود تحد من حركته

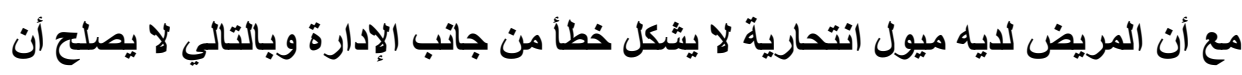

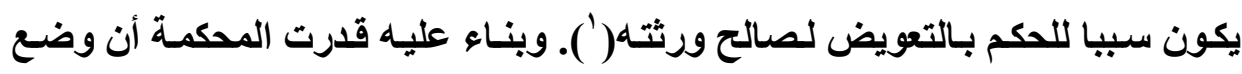

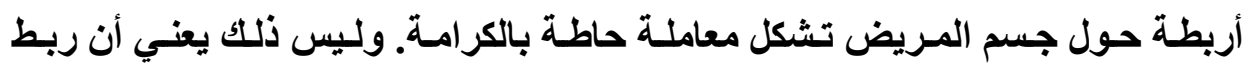
المريض هو دائما مهين للكرامة الإنسانية إذا كان له ما يبرره. ـالمقصود بالحق في بيئة علاجية ملائمة: قرر القانون المصري (مادة بـ من قانون رعاية المريض النفسي) كما قرر

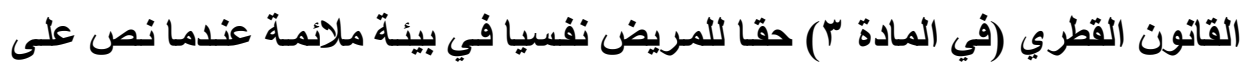
مجموعة من الحقوق المتعلقة بها وهي: ا ـ تلقي الرعاية العلاجية اللازمـة حسب حالته، في بيئة آمنـة ثُراعى فيها شروط

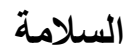

20 avr. 2011, obs. Bachelet, CEDH 24 sept. 1992, req. $\mathbf{n}^{0}$ 10533/83 풀, Herczegfalvy c/ Autriche, série A, no 244, § 63 ; RTDH 1993. 433, obs. Callewaert ; RUDH 1993. 1, obs. Sudre

(') CAA Marseille, 25 janvier 2007, André X, n 05MA01245, note de Karine MOREL 
r ـ احتـرام حقوقـه الفرديـة بتـوفير محسيط صـحي وإنساني يـصون كرامتـه ويفي باحتياجاته الطبية و الشخصية r- عدم تقييد حريته أو وضعه في غرفة عزل، إلا عند الحاجة التي يقدرها الطبيب المسؤول، ولمدة محدودة. وقد أكد القانون المصري ( في المادة ـ ـ منـه) على ذلك بقوله "لا يجوز تقييد حرية المريض جسدياً أو عزله بأية وسيلة دون اتباع الإجراءات القنية التي تحددها اللائحة التففيذية لهذا القانون". عـ إتاحة الحرية له في الحركة داخل المؤسسة، بحسب ما تسمح به حالته الصحية هـ الاحتفاظ بما في حوزته من متعلقات شخصية في صندوق الأمانـات بالمؤسسة، والتصرف فيها بالتنسيق مع الفريق المعالج، والحصول على خدمات الاتصالات

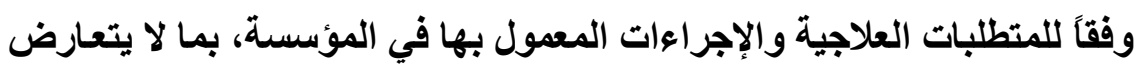
مع متطلبات السلامة

ـمقابلة زائريه أو رفض مقابلتهم ما لم تتعارض المقابلة مع الخطة العلاجية . ـ تمكينه من مقابلة محاميه ـ الحق في بيئة علاجية مناسبة في القانون القطري: فيما يتعلق بالعلاج سمح القانون القطري للمريض النفسي بدور في إدارة هذا العلاج، من مظاهر ذلك ما يلي: ـ الحصول على العلاج اللازم وفقاً للمعايير المتعارف عليها طبياً، ومنحهـ الفرصـة في المشاركة الفعلية والمستمرة في الخطة العلاجية ـ عدم جواز إخضاعه لأي بحث علمي إلا بعد إعلامه بتفاصيل هذا البحث و آثتاره، والحصول على موافقة كتابية منه، أو من ولي أمره، أو من الجهات المختصة 
في الدولة إذا لم يكن له ولي أمر، وفقاً للقانون وبحسب الأحوال، وكذلك عدم

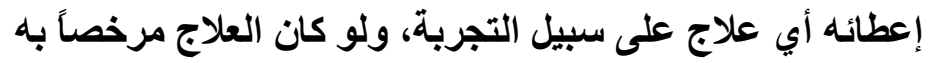
ـ أخذ رأيه في كل القرارات المتعلقة بعلاجه وخروجه من المؤسسة، وإعلامـه وولي أمره بالخدمات العلاجية المتوفرة في التأهيل، والحصول على كتاب من المؤسسة بالخطة العلاجية المناسبة له بعد خروجه - إثبات موافقته أو عدم مو (فقته على العلاج في ملفه الطبي، بمعرفة الطبيب المسؤول

ويحرص القانون المصري و القوانين المقارنـة على تحقيق استقلالية المريض وخصوصيته على الوجه التالي. وفي ذلك سمح لله بالتالي: ـ قبول ورفض مقابلة الزائرين، بما لا يتعارض مع الخطة العلاجية ـ الحمايـة مـن الاستغلال الاقتصـادي والجنسي ومـن الإيذاء الجسدي والنفسي و المعاملة المهينة بأي وجه، سواء من العاملين أو المرضى الآخرين (مـادة بـ

$$
\text { من القانون المصري). }
$$

ـ عدم معاقبته بدنياً أو معنوياً أو تهديده بأي وجه، أياً كانت الأسباب

ـ حمايـة خصوصياته ومتعلقاتهـ الثخصية ومكسان إقامته بالمؤسسة، وحمايـة

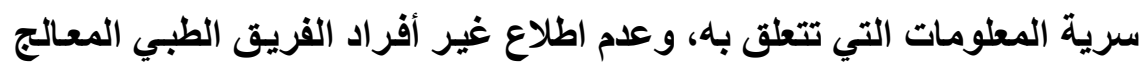

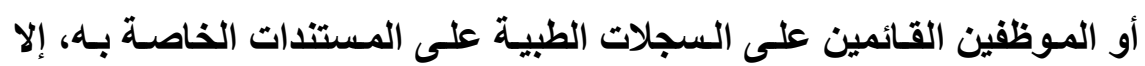

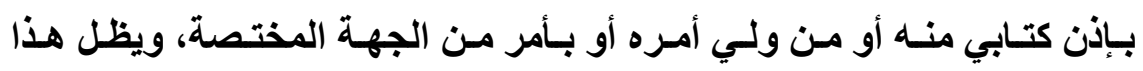

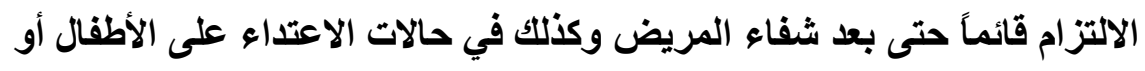
الثكك في وجود اعتداء. كما يحق المجلس القومي للصحة النفسية في تكوين 
لجنه فنيه من الأطباء المتخصصين يكون لها الحق في الاطلاع على سجلات المرضى طبقا للبند رقم ؛ من المادة V من القانون المصري.

ويتعين - وفقـا للقـانون المصري والمقـارن ـ حمايـة سـرية المعلومسات التـي تتعلق به ويملفه الطبي وعدم إفثاء تلك المعلومات لغير الأغراض العلاجية إلا في حالة طلب المعلومات من جهة قضائية أو وجود احتمال قوى بحدوث ضرر خطير أو إصابة وخيمة للمريض أو الأخرين (مادة \ب) من القانون المصري).

وتؤكد المادة (q ب) من القانون المصري على سرية المعلومات الطبية الخاصة بـالمريض النفسي بالنسبة لغير الفريق الطبي بقولها " لا يجوز لغير أفراد الفريق

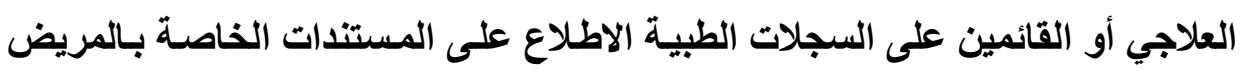
إلا بإذن كتابي منه. كما لا يجوز استخراج صورة منها إلا بإذن من المجلس الإقليمي

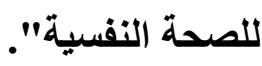

- حق المريض النفسي في الحماية من التجارب البحثية في القانون الفرنسي: نظم القانون الفرنسي في المادة L. 1121 من قانون الصحة العامـة إجراء

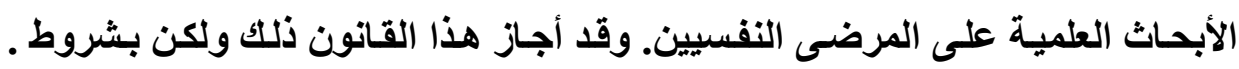

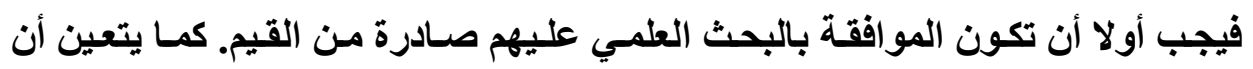

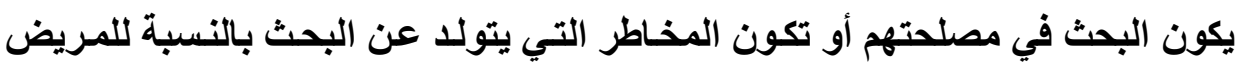

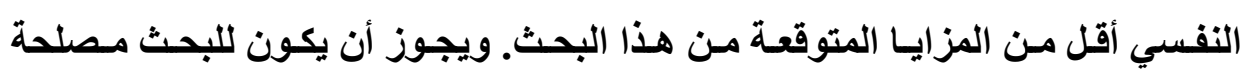

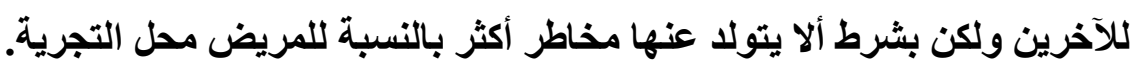
ـ عدم جواز نقل الأعضاء من المريض النفسي: لا يجوز نقل الأعضاء من المريض النفسي الحي أو نقل أنسجة منه. وكذلك الأمر بالنسبة للقاصر غير المريض. فكلاهمـا لا يجوز نقل الأعضاء منهمـا (مسادة 


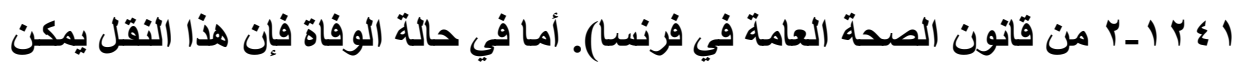

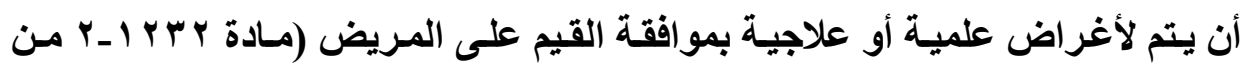
قانون الصحة العامة في فرنسا).

\section{الإطلب الرابع \\ حقوق المريض النفسي المتهم في الدعوى الجنائيسة}

يحدث أحيانـا أن يكون المريض النفسي متهمـا في قضية جنائية. هنـا يلـزم

تحقيق مقدار من الرعاية والاهتمـام بـه لا تقل عن تلك التي يوفرهـا القانون للشخص

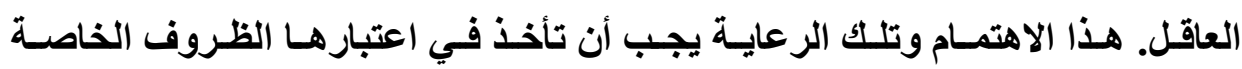
بالمريض النفسي والتي لـم تصل بـه إلى فقدان الأهليـة وبالتـالي فِإن السلطات تقدمـه

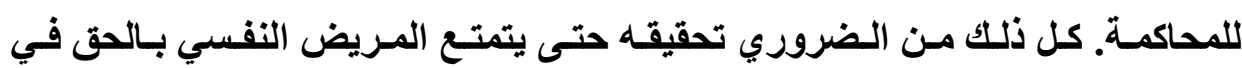

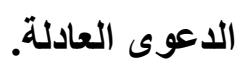
ـ ضرورة إعلام الولي عند اتهام المصاب باضطراب نفسي: يقع على سـلطات التحقيتق وسـلطة المحاكمـة واجبـاً بإخطـار الـولي وقاضـي الوصاية بالإجراعات المختصة ضد المتهم الموضوع تحت الحماية القانونية. ويعد ذلك بايلا عن تمتع المتهم بـالحق في الدفاع. فإذاذا كـان هذا النوع من المتهمين يعـاني من ضعف ملكاته العقلية بمـا يحول دون ممارسـة حقـه في الدفاع عن نفسه، فِان توكيل محام من قبل الولي أو قاضي الوصاية لا يغتي عن أن المتهم في هذه الحالة لـم يتمتع بحقه في الدفاع.

وقد عالج قانون الإجراءات الجنائية المصري تلك المشكلة (q ب ب) بنصه على أنه "إذا ثبت أن المتهم غير قادر على الدفاع عن نفسه بسبب اضطراب عقلي طرأ بعد وقوع الجريمة - يوقف رفع الدعوى عليه أو محاكمته حتى يعود إليه رشـده ، ويجوز 
في هذه الحالة لقاضـي التحقيق أو للقاضـي الجزائي كطلب النيابة العامـة أو المحكمة المنظورة أمامها الدعوى إذا كانت الواقعة جنايـة أو جنحة عقوبتها الحبس - إصدار

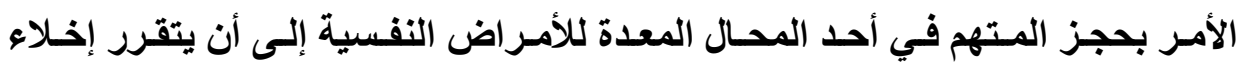

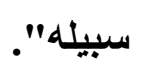

وفي نفس الاتجاه نصت المادة ـ ـ إ من قانون العقوبات القطري على أنه "إذا

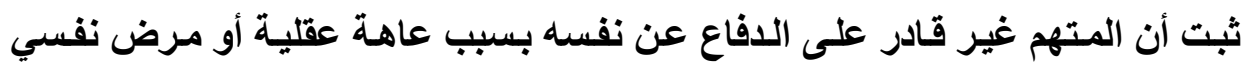

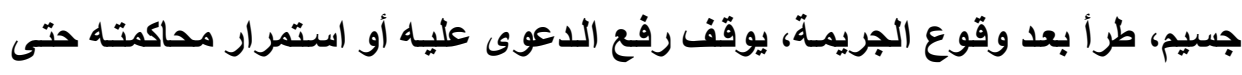

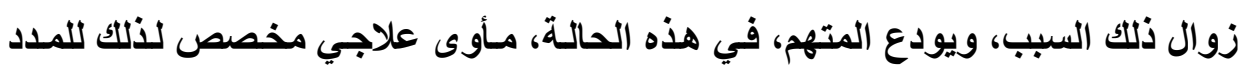

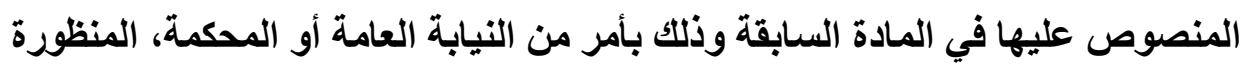
أمامها الدعوى، حسب الأحوال. ولا يحول وقف الدعوى دون اتخاذ إجراءات التحقيق التي يرى أنها مستعجلة ولازمة".

وقد حلت تلك المشكلة أيضا محكمة النقض الفرنسية عندما قضت بـأن على

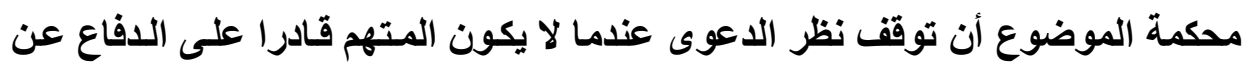
نفسه بسبب نقص ملكاته العقلية حتى تتحسن تلكت الملكات. ولا يغتي عن ذلك التك إخطار

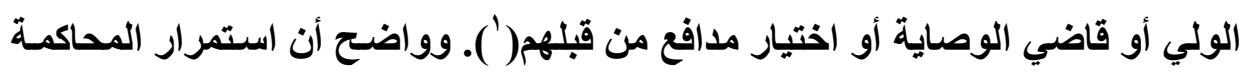
رغم تلك الظروف يعيب الحكم بالبطلان(").

(') Crim. 19 sept. 2018, n $^{0}$ 18-83.868 .

$\left.{ }^{(}\right)$Crim. 3 mai 2012, $n^{0}$ 11-88.725, Bull. crim. $n^{0} 105$; Dalloz actualité, 21 juin 2012, obs. Girault ; D. 2012. Actu. 1615, obs. Girault ; Dr. pénal 2012. Chron. 7, obs. Lesclous. 
وقـ أدانـت المحكمـة الأوربيـة لحقـوق الانسان فرنسـا بسبب محاكمتهـا لأحــ

الأثخاص المضطربين عقليا ـ الذي اتهم بالاعتداء الجنسي على فتاة لم تبلغ ه 1 سنة ـ دون إعلام الولي له بالمحاكمة. وكاتت السلطات الفرنسية قد تمسكت بعدم وجود نص صـريح بـللك في القـانون الفرنسي وبـأن المـتهم في هذه الحالـة قد تمتـع بحقـه في المحاكمة العادلة. مع ذلك قضت المحكمة الأوربية بأن ذلك يخـالف الحق في محاكمة عادلة الأي تكرسه المادة (†) من الاتفاقية الأوربية(').

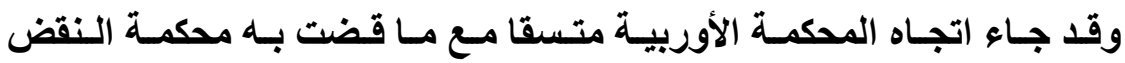

الفرنسية في قضية سـابقة أكدت فيهه على أن المتهم البالغ الذي هو تحت الحمايـة القانونية بإثـر اف الوصسي ومتهم آخر بسبب الاضطراب العقلي لا يمكن حرمانسه من الافاع من جانب الوصي والقيم(r).

وبناء على قضاء المحكمة الأوربية السابق عدل المشرع الفرنسي من موقفهـ

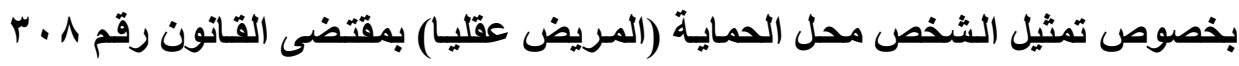
لسنة V . . . الصادر في • مـارس سنة V . . . لكي يستلزم تمثيل هذا المريض من جانب الولي عليه ( المادة 7 . V V V V من قانون الإجراءات الجنائية الفرنسي).

(') CEDH 30 janv. 2001, req. $\mathbf{n}^{0}$ 35683/97, Vaudelle c/ France, JCP 2001. I. 342, $\mathrm{n}^{0}$ 14, obs. Sudre ; JCP 2001. II. 10526, note Di Raimondo ; D. 2002. 353, note Gouttenoire-Cornut et Rubi Cavagna ; D. 2002. Somm. 2164, obs. Lemouland ; JCP 2001. II. 10526, note Di Raimondo ; Dr. fam. 2001, no 66, obs. Fossier ; LPA 19 nov. 2001, note Massip ; RTD civ. 2001. 330, obs. Hauser ; 2001.439, obs. Marguenaud ( ${ }^{2}$ Crim. 8 mars 2000, $n^{0}$ 99-82.597, Bull. crim. $n^{0} 110$ 


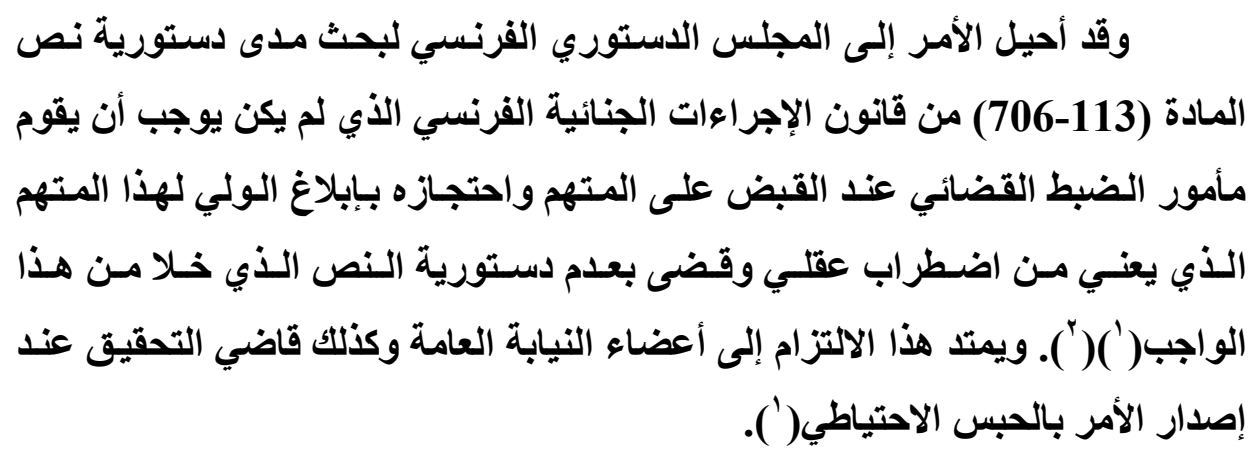

(1) Cons. const. 14 sept. 2018, $\mathrm{n}^{0}$ 2018-730 QPC

(') Article 706-113

Modifié par LOI $\mathbf{n}^{\circ 2008-174}$ du 25 février 2008 - art. 4 "Le procureur de la République ou le juge d'instruction avise le curateur ou le tuteur, ainsi que le juge des tutelles, des poursuites dont la personne fait l'objet. Il en est de même si la personne fait l'objet d'une alternative aux poursuites consistant en la réparation du dommage ou en une médiation, d'une composition pénale ou d'une comparution sur reconnaissance préalable de culpabilité ou si elle est entendue comme témoin assisté.

Le curateur ou le tuteur peut prendre connaissance des pièces de la procédure dans les mêmes conditions que celles prévues pour la personne poursuivie.

Si la personne est placée en détention provisoire, le curateur ou le tuteur bénéficie de plein droit d'un permis de visite.

Le procureur de la République ou le juge d'instruction avise le curateur ou le tuteur des décisions de non-lieu, de relaxe, d'acquittement, d'irresponsabilité pénale pour cause de trouble mental, ou de condamnation dont la personne fait l'objet.

Le curateur ou le tuteur est avisé de la date d'audience. Lorsqu'il est présent à l'audience, il est entendu par la juridiction en qualité de témoin". 


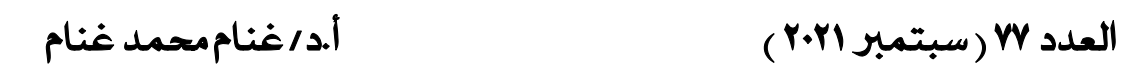

وتعطي المسادة 706-113 , al. 2 إجراءات فرنسي للقيم على الشخص محل

الحماية القانونية بسبب اضطراب عقلي وضعا قانونيا بدلا من المتهم. من ذلك الحق في

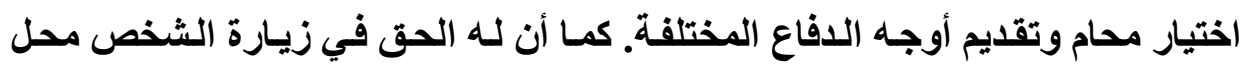

Conformément à la décision du Conseil constitutionnel $n^{\circ}$ 2018-730 QPC du 14 septembre 2018 :

- le premier alinéa de l'article 706-113 du code de procédure pénale, dans sa rédaction résultant de la loi ${ }^{\circ}$

2008-174 du 25 février 2008 relative à la rétention de sûreté et à la déclaration d'irresponsabilité pénale pour cause de trouble mental, est contraire à la Constitution ;

- l'abrogation de ces dispositions est reportée au 1er octobre 2019 ;

- les mesures prises ayant donné lieu, avant cette date, à l'application des dispositions déclarées contraires à la Constitution et les mesures de garde à vue prises avant cette date ne peuvent être contestées sur le fondement de cette inconstitutionnalité:

https://www.legifrance.gouv.fr/codes/id/LEGIARTI000018171042/201403-20/

(1) (art. 706-113, al. $1^{\text {er }}$, déclaré inconstitutionnel par : Cons. const. 14 sept. 2018, $\mathbf{n}^{0}$ 2018-730 QPC, mais dont l'abrogation est reportée au $1^{\mathrm{er}}$ octobre 2019. - Pour une illustration : V. Crim. 14 avr. 2010, $\mathrm{n}^{0} 09$ 83.503, AJ fam. 2010. 282, note Pécaut-Rivolier ; AJ pénal 2010. 409. - Crim. 28 sept. 2010, no 10-83.283, Bull. crim. no 144 ; AJ pénal 2011. 192 . - Crim. 3 mai 2012, Bull. crim. $n^{0} 105$; Dalloz actualité, 21 juin 2012, obs. Girault ; D. 2012. Actu. 1615, obs. Girault ; Dr. pénal 2012. Chron. 7, obs. Lesclous. - Crim. 27 nov. 2012, Bull. crim. $\mathbf{n}^{0} 258$; Dalloz actualité, 19 déc. 2012, obs. Bombled ; AJ pénal 2013. 169, obs. Perrier . - Crim. 29 janv. 2013, Bull. crim. n $^{0} 32$; Dalloz actualité, 18 févr. 2013, obs. Gayet ; D. 2013. Actu. 66 - - Crim. 19 déc. 2017, $n^{0}$ 17-85.841, inédit au Bull. crim.). 
الحماية في حالة حبسه احتياطيا. كما يجب أن يخطر القيم بقرارات التحقيق من حفظ

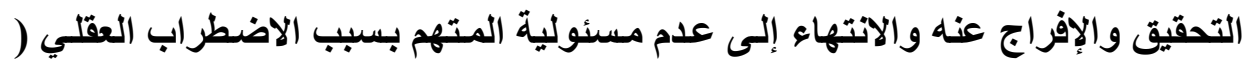

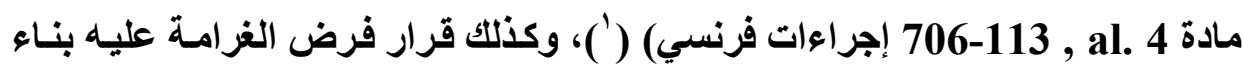
على أمر جنائي(مادة . (D. 47-18, al. 2) من قانون الإجراءات الجنائية الفرنسي). ومن الواضح أنه في حالة تو افر تعارض في المصالح بين مصلحة المتهم تحت الحماية

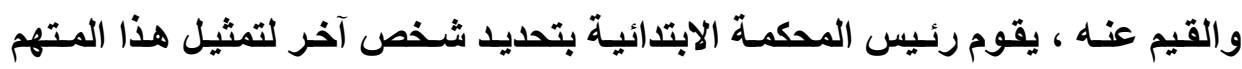

ويثار التساؤل عن الجزاء المترتب على الإخلال بهذا الالتزام؛ هل هو البطلان

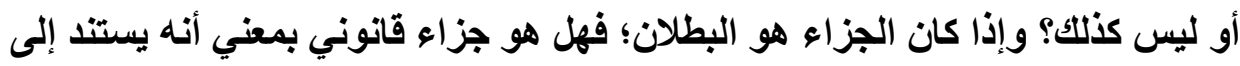

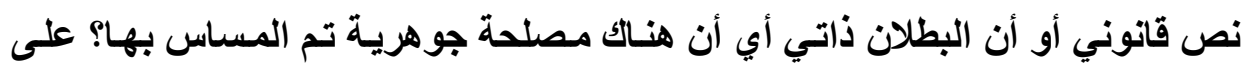

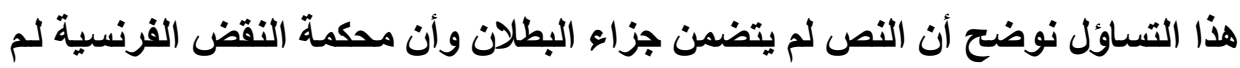

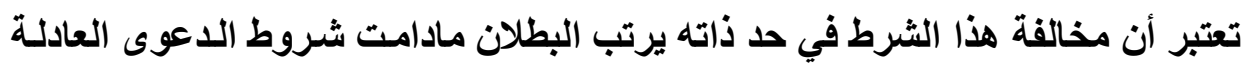

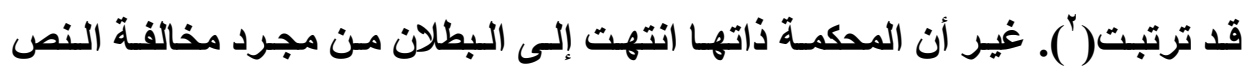

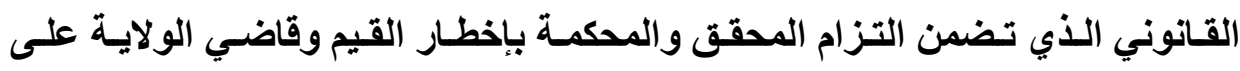

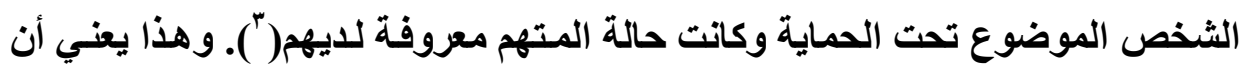

(1) Crim. 14 avr. 2010, $n^{0}$ 09-83.503, Bull. crim. $n^{0} 74$; AJ fam. 2010. 282, note Pécaut-Rivolier ; AJ pénal 2010. 409 . - V. plus récemment, Crim. 29 janv. 2013, n $^{0}$ 12-82.100, Bull. crim. $n^{0} 32$; Dalloz actualité, 18 févr. 2013, obs. Gayet ; D. 2013. Actu. 366

( $^{2}$ Crim. 28 sept. 2010, no 10-83.283, Bull. crim. no 144 ; AJ pénal 2011. 192

$\left(^{3}\right)$ Crim. 3 mai 2012, $n^{0} 11-88.725$, Bull. crim. $n^{0} 105$; Dalloz actualité, 21 juin 2012, obs. Girault ; D. 2012. Actu. 1615, obs. Girault ; Dr. pénal 2012. Chron. 7, obs. Lesclous). 
البطلان جزاء لمخالفة إجراء جوهري (نظريـة البطلان الذاتي)('). ومن الواضح أن

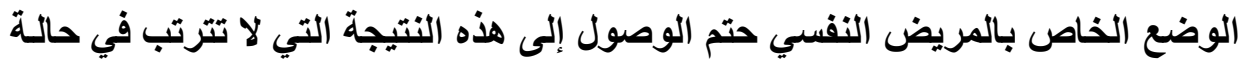

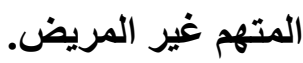

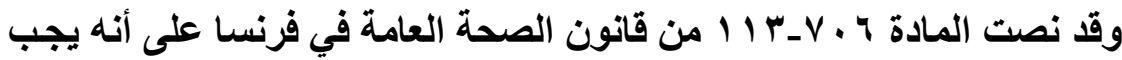

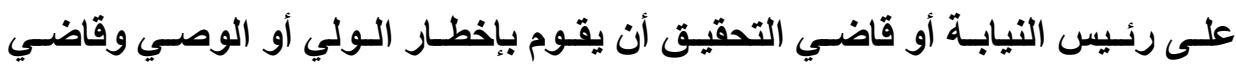

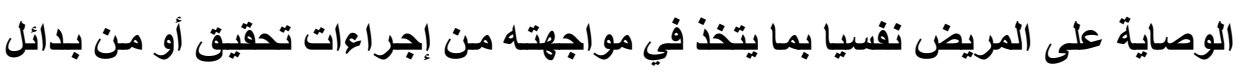
للإجراءات الجنائية ومنها المصالحة و التعويض والوضع تحت المراقبة. كما تتص على فلى التصائ أن القيم أو الوصي لهه أن يطلع على الأوراق التي تخص المريض. وفي حالة حبس التبل المريض احتياطيا للقيم والوصي أن يقوم بزيارته في محبسه. وعند صدور أمر بألا وجه يتعين على السلطات إخطار القيم والوصي كذلك الأمر في حالة اتخاذ قرار بأن المريض غير مسئول جنائيا. وفي حالة رفع الدعوى على المريض يتم هذا الإخطار أيضا كما يسمع القيم والوصي بصفته شاهدا في الدعوى.

غير أن للمحكمة أن تقدر أنه على الرغم من الاضطراب العقلي الذي يعاني منه

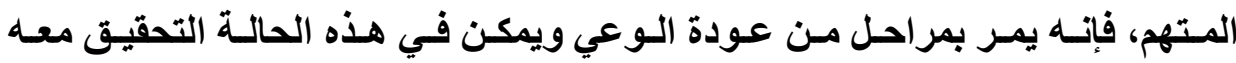

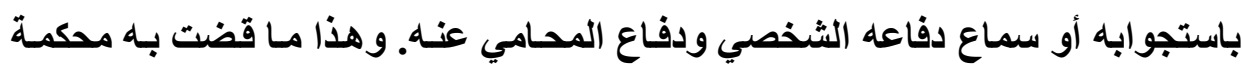

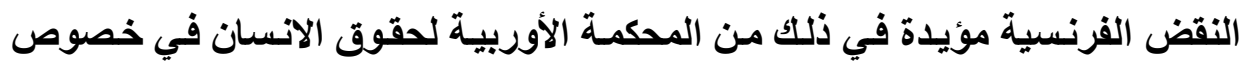

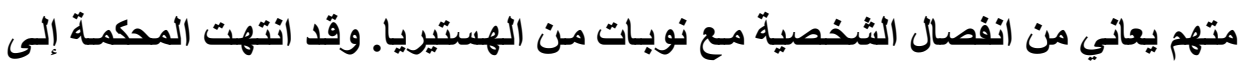

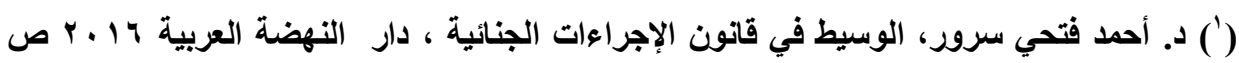

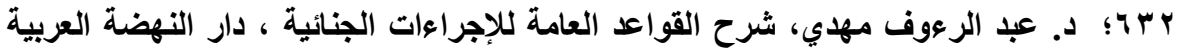


تمتع المتهم بالحق في الافاع بالنظر إلى ظروفه وبالنظر إلى استعانته بمحام مخضرم،

$$
\text { بالإضافة إلى متابعة من الولي لله ('). }
$$

وقد أثير التساؤل عن تطبيق تلك الأحكام على المتهم محل الحماية في مرحلة جمع الاستدلالات وخاصة عندما يتم القبض عليه واحتجازه من جاتب الشرطة. ذلكك أن المادة السادسة من الاتفاقية الأوربية تضمن للمتهم الحقى في دعوى عادلكة ولو كان

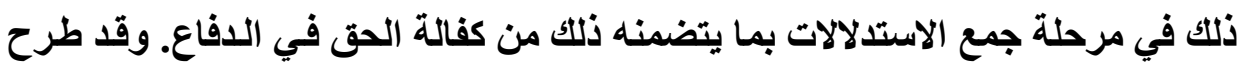

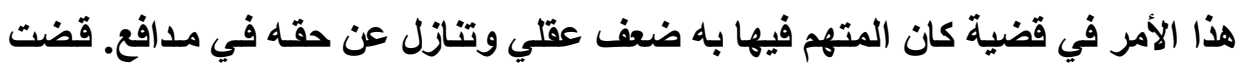

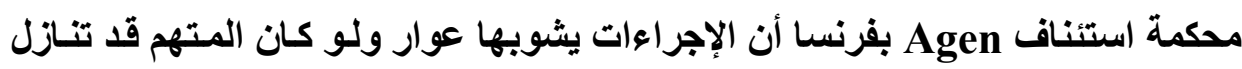

$$
\text { صراحة عن حقه في المدافع('). }
$$

وتسري تلك الأحكام من باب أولى في مرحلة المحاكمة إذا طرأ على المتهم مـا

يشكل اضطرابا عقليا في أثناء الإجراءات وليس عند ارتكابه الجريمـة، حيث يتعين أن أن النئ

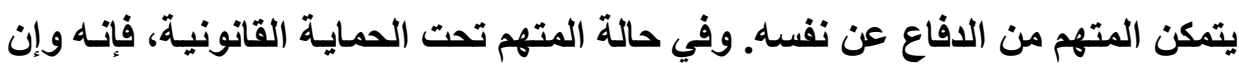
كان محل مساعدة من الولي ومن العدافع عنه، فِان هذا لا يكفي لتمتعه بالحق في مدافع

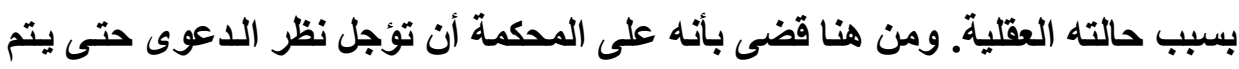

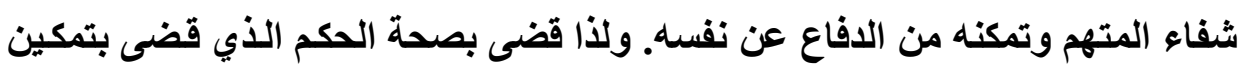

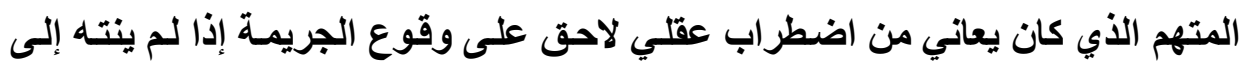

(') affaire G. c/ France (CEDH 23 févr. 2012, req. nº 27244/09

${ }^{(2)}$ Agen, 18 févr. 2010, Juris-Data $\mathbf{n}^{0}$ 2010-003487. - V. aussi à propos de cet arrêt : CAPDEPON, La régularité d'une garde à vue à la lumière du droit européen : Dr. pénal 2010. Étude 25. - FOURNIÉ, Faut-il garder le silence ?, D. 2010. 1850 
البراءة ولكن إلى تمكين هذا المتهم من الدفاع عند إفاقته من هذا الاضطراب ('). في هذا المعنى تنص المـادة ( • V \& ) من قانون الإجراءات الجنائية الفرنسي على أنها إذا تبين لمحكمة الموضوع أن المتهم مصاب باضطر اب عقلي دائسم يحول دون ممارسته لحقه في الدفاع، فمن واجب المحكمة أن تؤجل نظر الدعوى حتى يتم شفاؤه، ولو كـان لله محام يدافع عنه وولي يمثله".

وفي حالة اضطراب المتهم لملكاتـه العقلية عند نظر الطعن، فِإن على محكمة الطعن أن تؤجل نظر اللدعوى أيضا. ويسري هذا الإجراءات أمسام محكمة النقض عند

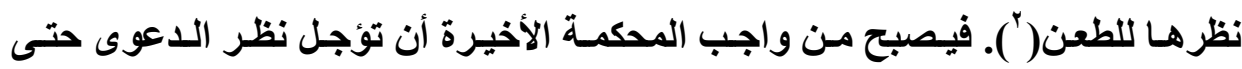
يسترد الطاعن ملكاتـه العقلية. غير أن هذا الأثر على الحكم الجنـائي المطعون فيه لا يمتد إلى الثث المدني الذي يصبح واجب التنفيذ.

وإذا صدر الحكم بالإدانـة وأصبح باتـا واتضح أن المحكوم عليه كـان مصابا باضطر اب عقلي في اثناء المحاكمة ولم تكن محكمة التمييز - باعتبار هـا آخر محكمة نظرت الدعوى- قد تفطنت إلى حالة المحكوم عليه، فإن هذا الأخير لـه أن يقدم التمـساس إعادة النظر باعتبار أن الأمر يتعلق بواقعة جديدة ومن ثم إلغاء الحكم الصادر بالإدانـة،

(') Crim. 10 juin $1985, n^{0}$ 84-90.432, Bull. crim. $n^{0} 221$; Crim. 5 sept. 2018, $\mathrm{n}^{0}$ 17-84.402, Dalloz actualité, 14 sept. 2018, obs. Fucini

$\left(^{2}\right)$ Crim. 5 juin 1997, $n^{\circ}$ 96-82.783 , Bull. crim. $n^{0} 228$; JCP 1997. II. 22908, rapp. Larosiere de Champfeu. - Comp. auparavant Crim. 31 oct. 1912, Bull. crim. no 525 
وعلى محكمـة الإحالـة أن تؤجـل نظر الـدعوى وفقـا للقواعد المعمـول بهـا في هـذه

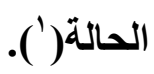

في الفرض الذي فيه يصاب المحكوم عليه باضطر اب عقلـي في اثنـاء تنفيذه

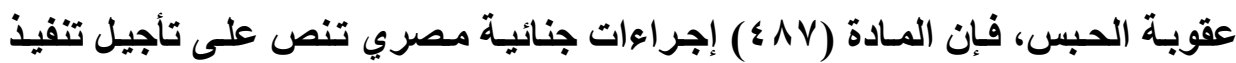

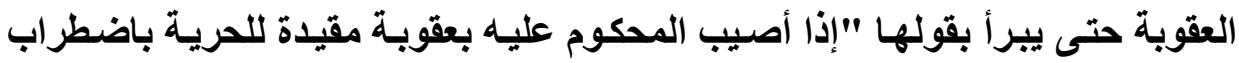
عقلي، وجب تأجيل تنفيذ العقوبة حتى يبرأ. ويجوز للنيابة العامـة أن تأمر بوضعاه في أحد المحال المعدة للأمراض النفسية، وفي هذه الحالة تستنزل المدة التي يقضيها في هذا المحل من مدة العقوبة المحكوم بها".

غير أن المحاكم الفرنسية رفضت منح الإفراج الثرطي استنادا إلى أن المحكوم عليه مصاب باضطر اب عقلي('). وقد أدخل المشرع الفرنسي تعديلات تدل على أنسه لـ يعتبر الاضطراب العقلي سببا لتعليق تنفيذ عقوبـة وإنمـا أدخل العلاج الطبي والنفسي كعنصر من عناصر برامج يخضع لها المسجون الخاضع لنظام الإفراج مـع خضوعه

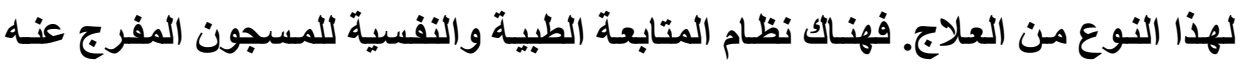

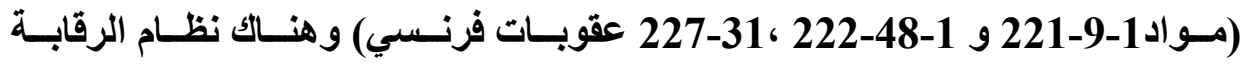

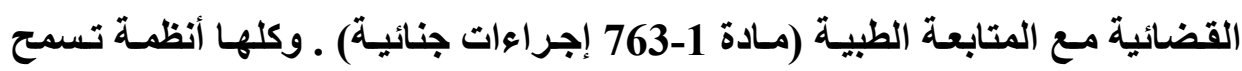
بتنفيذ جزء من العقوبـة في خـارج السجن مـع خضوع المسجون الخطر المفرج عنـه للعلاج الطبي ومن ذلك العلاج النفسي. يضاف إلى ذلك ما أدخلـه المشرع الفرنسي من وحدات خاصة يتم حجز المصابين باضطر ابات عقلية في السجون فيها (مسادة 398

(') Crim. 3 mai 1994, $\mathrm{n}^{0}$ 93-85.663, Bull. crim. $\mathrm{n}^{0} 163$; D. 1995. Somm. 144, obs. Pradel . - Crim. 27 mai 1997, $n^{0}$ 96-85.081 एँّ Bull. crim. $n^{0} 205$. V. Révision [Pén.]

$\left.{ }^{2}\right)$ JNLC, 23 nov. 2001, D. 2002. 837, note Herzog-Evans 
إجراعات فرنسي). ويلاحظ أنه في هذه الحالة الأخيرة يظل المسجون تابعـا للسلطة القضائية وليس لوزارة الصحة. وبنـاء عليه فإنـه إذا صدر قرار قضائي بـالإفراج عن المسجون، فإنه يتم تنفيذه فورا ودون الرجوع إلى إدارة الطب النفسي. - حق المحكوم عليه المضطرب نفسيا في نظام خاص بحبسه:

تنص بعض التشريعات ـ مثل القانون المصري - على هذا الحق. وقد تبنى

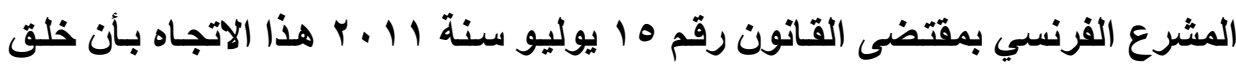
وحدة خاصة للعناية بالمسجونين أصحاب الاضطر ابات النفسية ونص عليها في قانون الصحة العامة (CSP, art. L. 3222-1) ـ ويعتبر ذلك أسلوبا لتنفيذ العقوبـة السالبة للحريـة. غير أن تنـاول المسجون للعلاج يظل مشروطا بموافقته. فإذا كانت حالته لا تسمح بذلك فإن القرار يؤول إلى المحافظ الذي يقع السجن في دائرته('). ـ معاملـة المسجون المضطرب نفسيا وحقوق الانسـان أمسام المحكمـة الأوربيـة

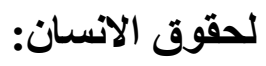

أثثيرت مسألة معاملة هذا النوع من المسجونين أمسام المحكمة الأوربية لحقوق الانسان من ناحية مدى تعلقها بحقوق الانسان وخاصة مدى احترامها لمبدا المعاملة الإنسانية التي تنص عليها الاتفاقية الأوربية لحقوق الانسان(ب). ففي كل مرة تكون

( ${ }^{1}$ ) Évelyne BONIS, Troubles psychiques - Malades mentaux, Répertoire de droit pénal et de procédure pénale, $\mathrm{N}^{0} 58$

( ${ }^{2}$ ) CEDH 3 avr. 2001, req. $n^{0}$ 27229/95, Keenan c/ RU. - Et CEDH 11 juill. 2006, req. $n^{0} 33834 / 03$, Rivière c/ France. $-V$. également pour le cas d'un détenu malade mental qui s'était suicidé en prison après un placement en cellule disciplinaire : CEDH 16 oct. 2008, req. $n^{0}$ 5608/05, Renolde c/ France, RSC 2009. 173, obs. Marguenaud ; RSC 2009. 439, obs. Poncela ; D. 2008. AJ 2723, obs. Len ; D. 2009. Pan. 123, obs. $=$ 
فيها المعاملة غير إنسانية فإنه المحكمة تقضي باعتبار ها مخالقة لأحكام الاتفاقية. وقد قضى بألك بخصوص أحد المسجونين الأي كان يعاني من انفصام في الثخصية وتم

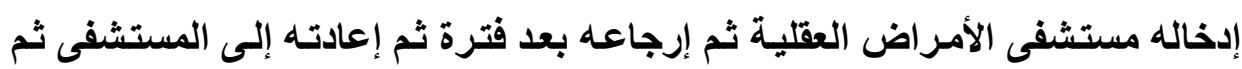

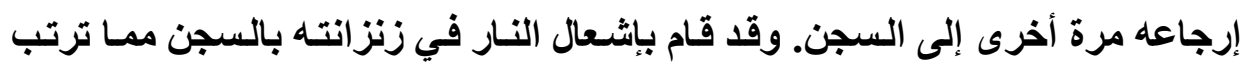
عليه وفاة زميل له من المسجونين. قضت المحكمة الأوربية لحقوق الانسان بأن إعادته إلى السجن يثكل معاملة غير إنسانية بالنظر إلى ظروفه النفسية والعقليةة('). ومؤدى ذلك أن السلطات العقابية تلتزم بتوفير معاملة مناسبة للمسجون بالنظر إلى حالته العقلية وأن تفسح أمامـه فرصـة لتطور حالته وتحسنها والاستفادة من هذا التحسن في شكل تخفيض مدة حبسه أو إيداعه. وقد قضت المحكمة الأوربية لحقوق الانسان بضرورة ذلك بالنسبة للمسجون الذي لا يعاني من اضطرابات عقلية. إذن فإن هذا المبدأ يسري على المسجون المضطرب عقليا. فقد قضي بأن مدة السجن يجب ألا تكون مؤبدة - من ناحية القانون أو من ناحية الواقعـ دون أن تفسح للمسجون العادي

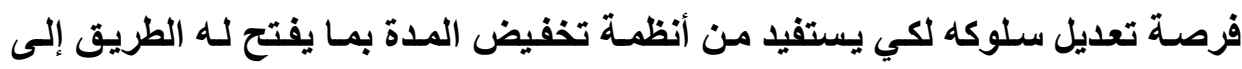

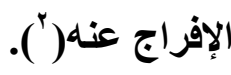

Roujou de Boubée, Garé et Mirabail ; D. 2009. Pan. 1382, obs. Céré ; AJ pénal 2009. 41, obs. Céré ; Dr. pénal 2009. Chron. 3, obs. Peltier; Dr. pénal 2009. Chron. 4, obs. Dreyer .

(1) CEDH, $5^{\mathrm{e}}$ sect., 23 févr. 2012, req. $\mathrm{n}^{0}$ 27244/09, Dalloz actualité, 13 mars 2012, obs. Bachelet; D. 2012. Actu. 742 ; AJ pénal 2012. 357, obs. Céré . - Comp. CEDH, 19 juill. 2012, req. $n^{0}$ 38447/009, K. c/ France

$\left(^{2}\right)$ CEDH, gde ch., 9 juill. 2013, Vinter et a. c/ Royaume-Uni, préc. - CEDH 18 mars 2014, req. ${ }^{\text {os }} 24069 / 03,197 / 04,6201 / 06$ et 10464/07, Öcalan c/ Turquie ( $\mathrm{n}^{0}$ 2); CEDH, gde ch., Murray c/ Pays-Bas, 26 avr. 2016, req. $n^{0} 10511 / 10$, Dr. pénal 2016. Comm. 120, note V. Peltier 
أما إذا تعلق الأمر بحجز المسجون بعد انتهاء مدة عقوبته في مؤسسة للعلاج النفسي والعقلي بسبب حالته التي تجعله خطرا على المجتمع ، فـإن المحكمة الأوربية لحقوق الانسان قد قضت بأن التشريع الذي يجيز ذلك لا يخـالف أحكام الاتفاقية ، ذلك أنه لا يشكل معاملة قاسية وغير إنسانية على الرغم من حجزه بعد انتهاء مدة عقوبته، ذلك أن الأمر يتعلق بالعلاج وليس بالعقاب، كما أن هنالك من الضمانات مـا يكفل عدالة

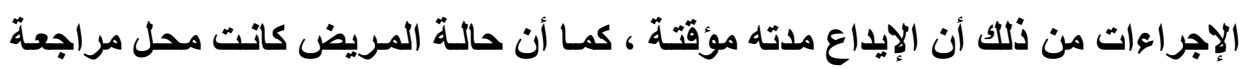

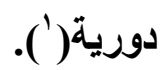

وقد أكدت المحكمة الأوربيـة لحقوق الانسـان أنـه مـن واجب الدولـة أن تـوفر

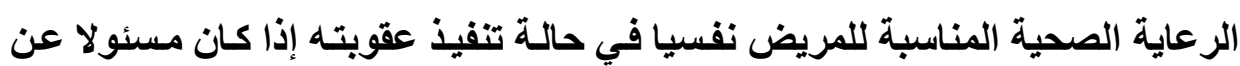
جريمته وقت ارتكابها ولكنه أصيب بالمرض بعد ذلك. ويكون هذا بتوفير أحياء مناسبة

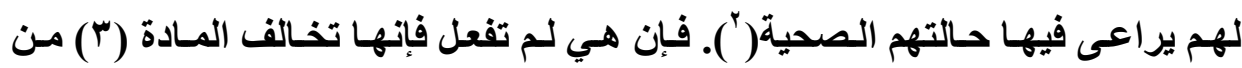
الاتفاقية إذا وصلت معاملة تلك الطائفة إلى الد الذي تثكل فيهه معاملة قاسية أو غير إنسانية بالنظر إلى ظروف هذا الحبس وعدم تقديم الرعاية المناسبة لهم(")( (").

(') CEDH 7 janv. 2016, Bergmann c/ Allemagne, req. $n^{0}$ 23279/14 321 qu, Dr. pénal 2016. Comm. 70, note V. Peltier.

$\left(^{2}\right)$ Kudta v. Poland [GC], no. 30210/96, § 94, ECHR 2000-XI; Mouisel v. France, no. 67263/01, § 40, ECHR 2002-IX; and Khudobin v. Russia, no. 59696/00, § 93, 26 October 2006)

$\left({ }^{3}\right)$ CASE OF A. AND OTHERS v. THE UNITED KINGDOM, 19 February 2009 (Application no. 3455/05)

$\left(^{4}\right)$, M.S. v. the United Kingdom, cited above, §§ 44-46; Wenerski v. Poland, no. 44369/02, $\S$ 56-65, 20 January 2009; and Popov v. Russia, no. 26853/04, $\S$ 210-13 and 231-37, 13 July 2006 
كما أصدرت لجنة الوزراء بالمجلس الأوربي توصية تتطلق بالمسجونين الذين

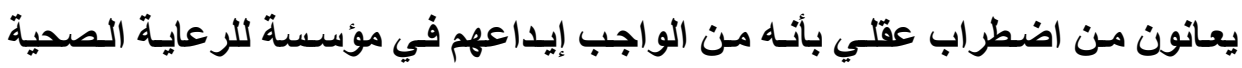

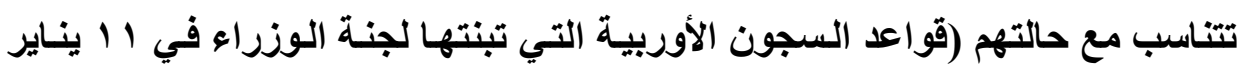

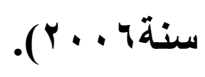

من المستقر عليه أن المحكوم عليه الذي يعاني من اضطرابات عقلية كما لو

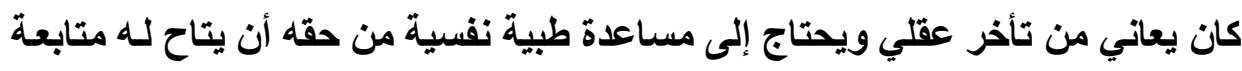
نفسية وطبية. كما أنه إذا تعلق الأمر بعقوبة الحبس المؤبد فإن قضاء المحكمة الأوربية

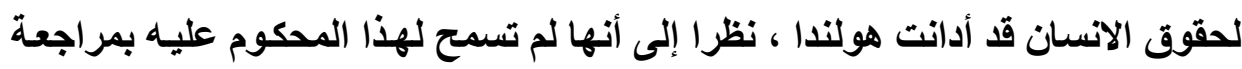

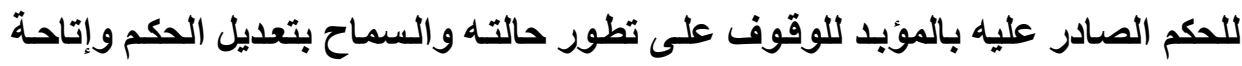
الفرصة له للتكيف مع المجتمع ('). وقد يتحول حبس المريض نفسيا إلى معاملـة غير إنسانية كمـا في قضية PAPOSHVILI v. BELGIUM التي تتلذص وقائعها في أن شخصاً أجنبياً يعاني من انفصام الثخصية كـان مطلوباً تسليمه إلى الولايـات المتحدة حيث يتهم

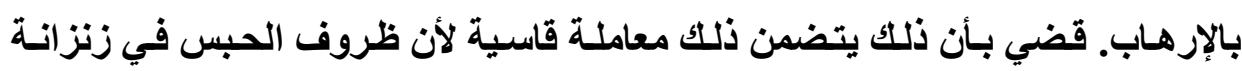

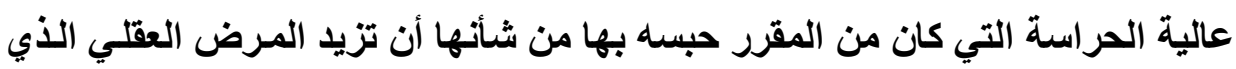

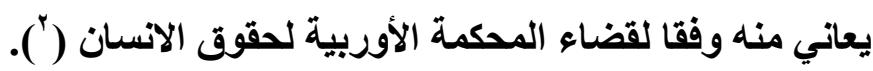

(') CASE OF MURRAY v. THE NETHERLANDS, 26 April 2016 (Application no. 10511/10)

${ }^{2}$ ) CASE OF PAPOShVILI v. BELGIUM, 13 December 2016, (Application no. 41738/10) 


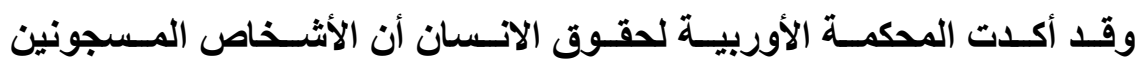

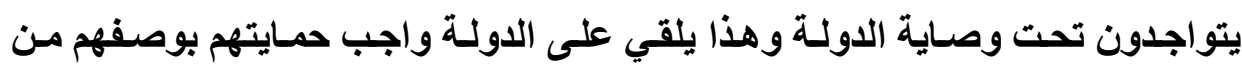

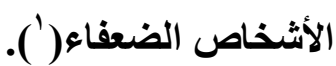

كمـا أكلت المحكمة أن عقوبة الحبس تتضمن آلامـا لا مفر منها. غير أنها إذا

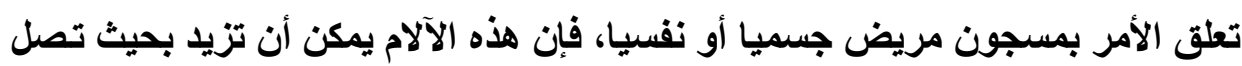

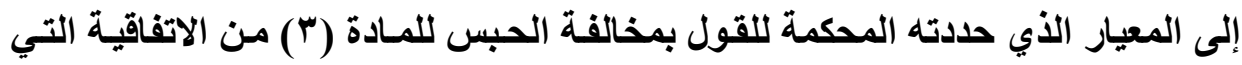

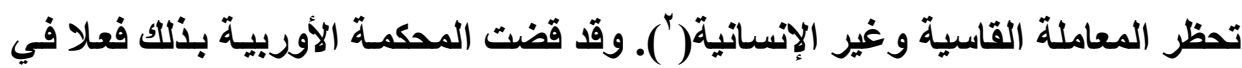

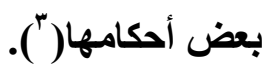

في ذلك قضت المحكمة بأن حبس المريض عقليا لا يجب أن تخلق لايهـ شعور

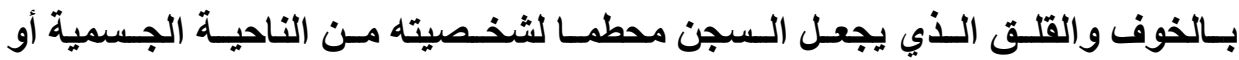

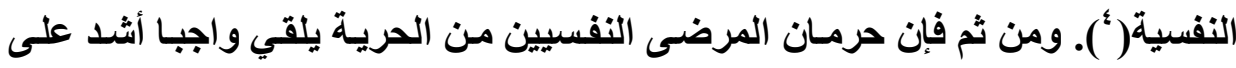

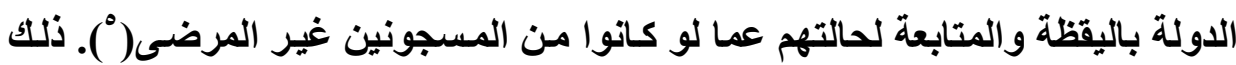

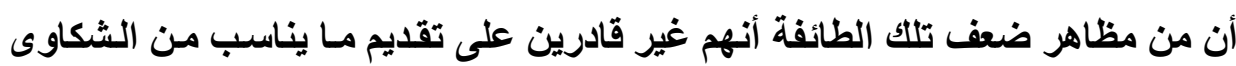
لرفع العناء عنهم في محبسهُ(").

(1) Enache v. Romania, no. 10662/06, § 49, 1 April 2014; M.C. v. Poland, no. 23692/09, § 88, 3 March 2015; and $A . S ̧$. v. Turkey, no. 58271/10, § 66, 13 September 2016

( $\left.^{2}\right)$ Hüseyin Yuldırım v. Turkey, no. 2778/02, § 73, 3 May 2007, and Gülay Çetin v. Turkey, no. 44084/10, § 101, 5 March 2013

$\left(^{3}\right)$ Kudta v. Poland [GC], no. 30210/96, § 94, ECHR 2000-XI; Rivière v. France, no. 33834/03, $§ 74,11$ July 2006; and Claes, cited above, $\$ \S 94-97$

${ }^{4}$ ) Selmouni v. France [GC], no. 25803/94, § 99, ECHR 1999-V

$\left(^{5}\right)$ Stawomir Musial v. Poland, no. 28300/06, § 96, 20 January 2009; see also Claes, cited above, $\S 101$

( $\left.{ }^{6}\right)$ Herczegfalvy v. Austria, 24 September 1992, § 82, Series A no. 244; Aerts v. Belgium, 30 July 1998, § 66, Reports of Judgments and Decisions $=$ 
وقد وضعت المحكمة الأوربية لحقوق الانسان معايير لحرمسان المريض النفسي

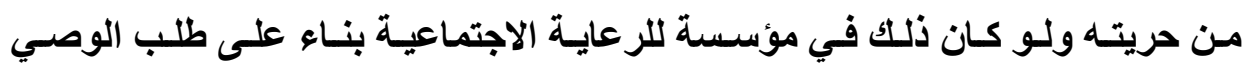
وبالتالي كان هذا الحرمان من الحرية بناء على نص يجيز ذلك. هذا النص لا يكفي، بل هل

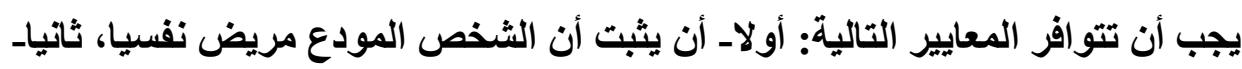

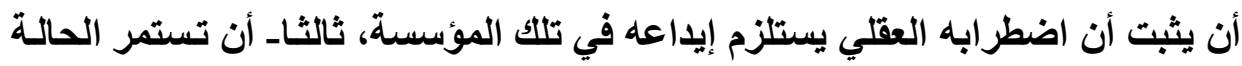

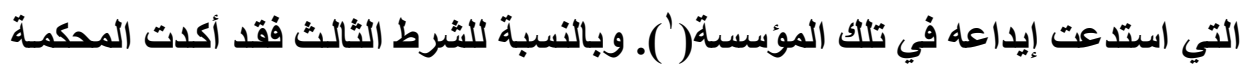

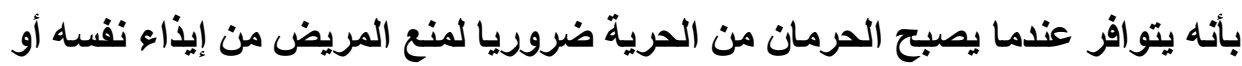

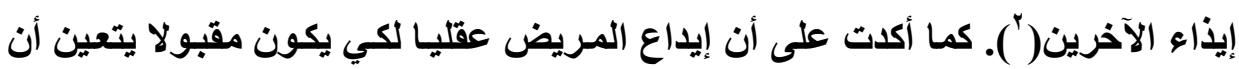

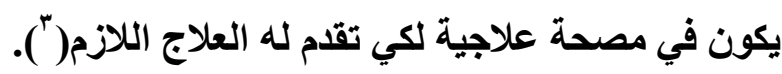

و من الواجب أن يتم احترام القانون الذي يستوجب أن يكون إقرار المواققة

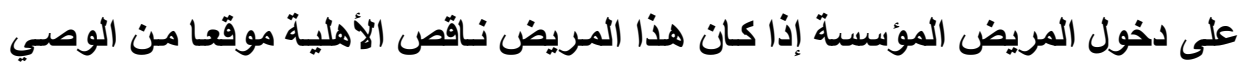

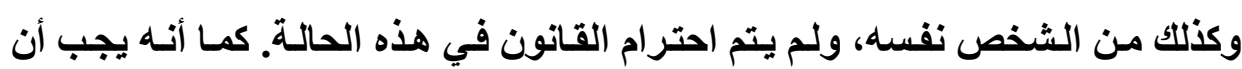

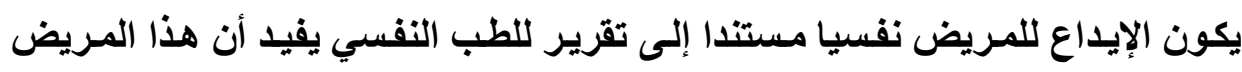

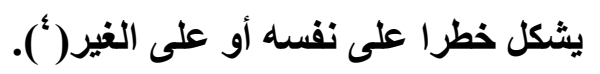

1998-V; and Murray v. the Netherlands [GC], no. 10511/10, $§ 106,26$ April 2016

(1) CASE OF STANEV v. BULGARIA, 17 January 2012 , (Application no. 36760/06)

(') Hutchison Reid v. the United Kingdom, no. 50272/99, § 52, ECHR 2003-IV

$\left({ }^{3}\right)$ see Ashingdane, cited above, $\S 44$, and Pankiewicz v. Poland, no. 34151/04, §§ 42-45, 12 February 2008

${ }^{4}$ ) Winterwerp, cited above, $\S 40$, and Luberti v. Italy, 23 February 1984, § 27, Series A no. 75 


\section{الخاتمة}

تنتهي هذه الورقة بخاتمة تتضمن أهم النتائج و التوصيات على الوجه التالي:

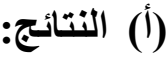

من أهم نتائج هذا البحث ما يلي:

- يستخدم القانون المصري والقطري تعبير المريض نفسيا حيث يقصد المريض

عقليا.

- يعرف المـصري والقـانون القطري أكثر مـن نـوع مـن الإدخـال لمستششفى الأمراض النفسية؛ الاخول الإرادي والاخول الإلزامي والاخول بناء على طلب أحد الأقارب بالإضافة إلى الاخول القضائي. - ونظرا لخطورة قرار الإيـاع الإلزامسي فقد أحاطته القوانين بضمانات مـن

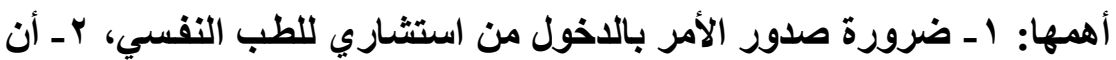

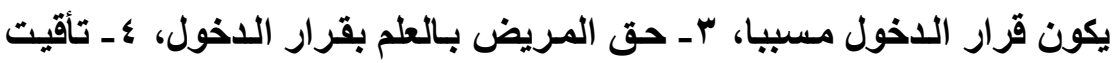
مدة الإيداع، هـ احترام الحق في التظلم والطعن في قرار الإدخال، جـ أولويـة

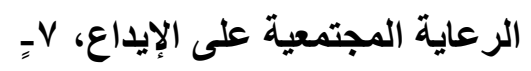

- تقرر عديد من التشريعات ومنها القانون المصري والقطري مجموعة من الضمانات والحقوق المقررة لصالح المريض نفسيا، من أهمها العلم بتشخيص

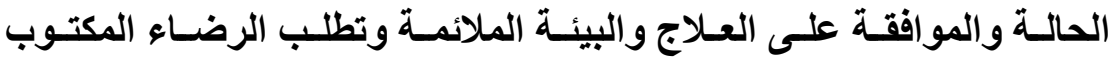
المستنير وعلدم تقييد حريته وحقه في الكرامة والمعاملة الإنسانية وحقه في الحركة والحفاظ على أسرار المريض نفسيا.

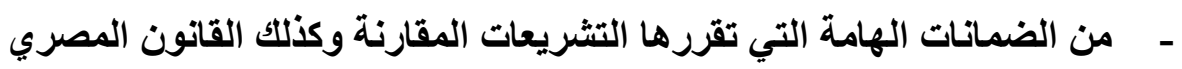
القطري حق المريض في التظلم من قرار الإذخال. 
- تقرر عديد من التشريعات ومنها القانون المصري والقطري حقا للمريض

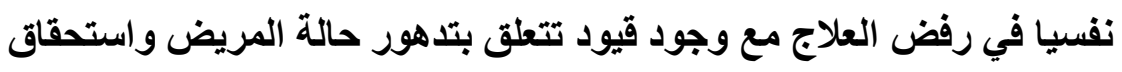

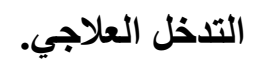
- أفرد القانون المصري والقطري وضعا خاصـا للعلاج الكهربائي حيث تطلب موافقة كتابة من المريض نفسه أو من ولي أمره.

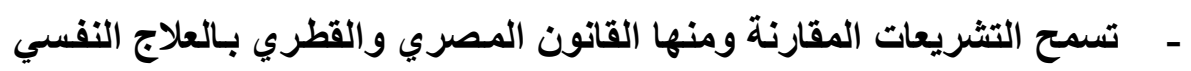

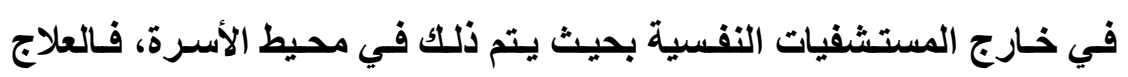

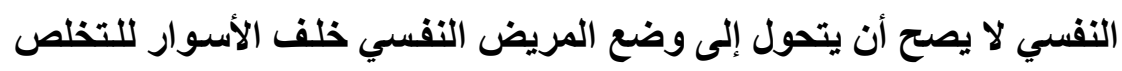
منه، بل مساعدته على الثفاء من المرض أو أو تخفيف آثاره.

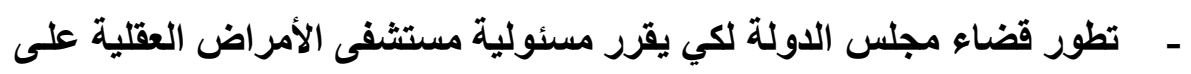
أساس الخطر العادي ولم يعد يستلزم توافر الخطأ الجسيم.

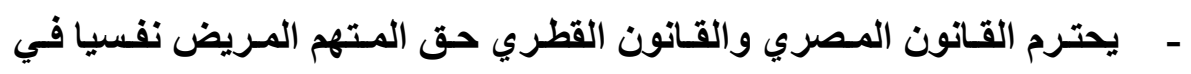

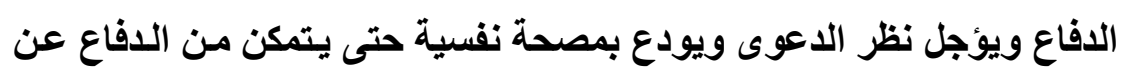

$$
\text { نفسه }
$$

$$
\text { نخلص إلى توصيات ، من أهمها: }
$$

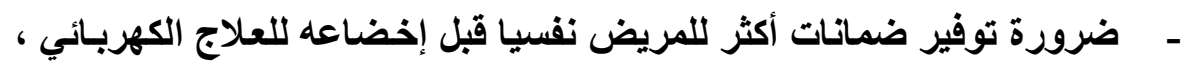

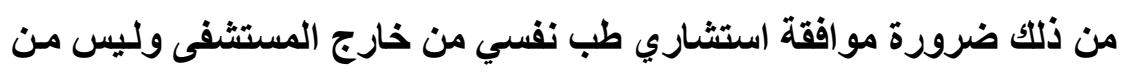

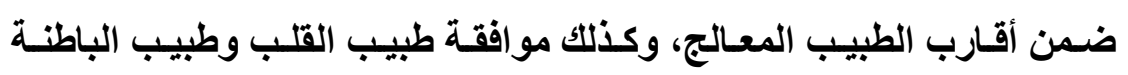

$$
\text { وطبيب التخدير. }
$$

- وجوب النص على إثراف جهة قضائية على مستثفى الأمراض النفسية مثل النيابة العامة في شكل تفتيش ومتابعة بالإضافة إلى الجهات الإدارية. 
- مـن المناسب تـوافر رقابـة إداريـة مستمرة لمستشفى الأمـراض العقلية مـن الجهات المختصة بوزارة الصحة. - ضرورة النص على حق المريض وأولياء أموره في الطعن في قرار الإدخال غير الإرادي أمام القضاء. وقد حددتها قو انين مقارنة (كالقانون الفرنسي) بأن الجهة المختصة بنظر الطعن هي القضاء الإداري لتعلق الأمر بقرار إداري.

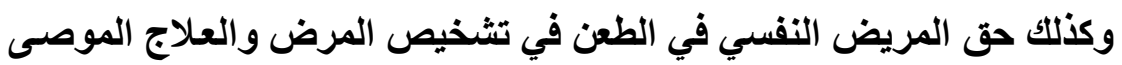
به أمام القضاء العادي هذه المرة. - من الضروري النص على حق المريض نفسا أو من يمثلـه في الطعن أمسام القضاء على أي قرار صادر من إدارة المستشفى.

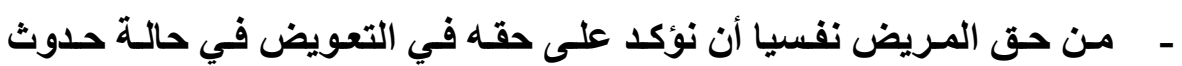

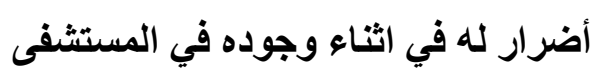
- من المناسب تقرير حق المريض في الحصول على تعويض بنـاء على تحمل المخاطر فلا يقتصر على حالة توافر الخطأ في جاتب إدارة المستشفى تأسيسا على وجود المريض نفسيا في رعاية المستشفى. عندئذ لا يطلب للقضاء لله بالتعويض أن يثبت تو افر هذا الخطأ من جاتب الإدارة.

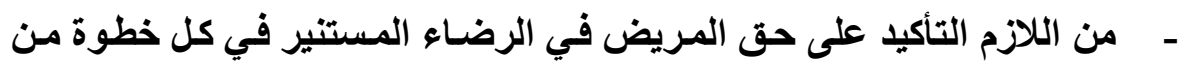

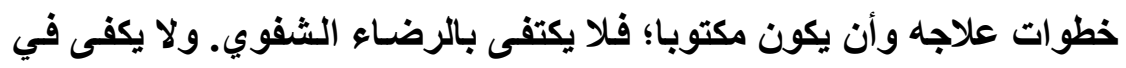

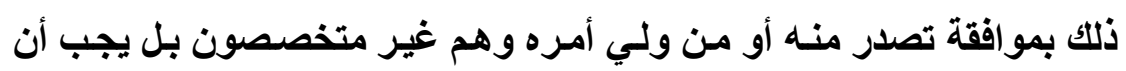
تكون آثار ونتائج العلاج مدونة كتابة. - نرى التوسع في استخدام العلاج في الوسط الحر أي الوسط العائلي لتشجيع

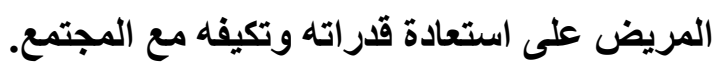


- نوصي أن يكون الاخول مؤقتا بمدة معينة قابلة للتجدد بعد متابعة مكتوبـة من فريق استثاري حتى لا يتحول الإيداع في مستثفى الطب النفسي إلى وسيلة لحجز المرضى النفسيين للتخلص منهم.

- نوصي أن يتبنى القانون القطري جميع الحقوق والحريـات التي قررهـا قرار

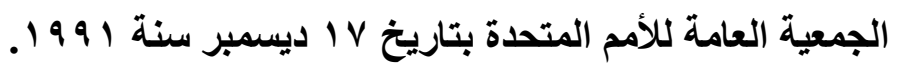
- يتعين أن يوجد نظام خاص لحبس المريض النفسي والنص على أنظمـة تسمح بالحجز العلاجي له بعد قضاء مدة عقوبته. 


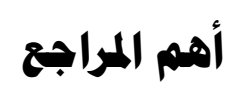

أولا - مراجع باللغة العربية:

ـ د. أحمد فتحي سرور، الوسيط في قانون الإجراءات الجنائية ، دار النهضة العربية

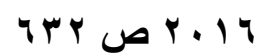

ـ د. عبد الرعاوف مهـدي، شـرح القو اعد العامـة للإجراءات الجنائيسة ، دار النهضة

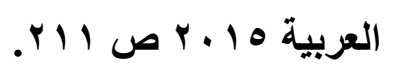

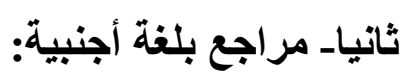

- Évelyne BONIS, Troubles psychiques - Malades mentaux, Répertoire de droit pénal et de procédure pénale, $N^{\circ} 58$

- Sandra MONOD, Le juge administratif et l'hospitalisation sans consentement, Master II (recherche) de droit public, 4 juillet 2008, Faculté de droit et de science politique,Université de Rennes,

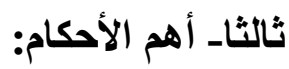

$$
\begin{aligned}
& \text { ـ ـ أحكام محكمة النقض والاستئناف الفرنسية } \\
& \text { - أحكام القضاء الإداري الفرنسي }
\end{aligned}
$$

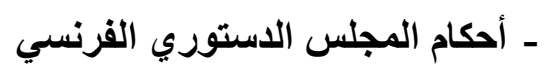

$$
\begin{aligned}
& \text { ـ - أحكام المحكمة الأوربية لحقوق الانسئوري العرئسي }
\end{aligned}
$$

